\title{
VARIAÇÃO GENÉTICA EM TRÊS GRUPOS DE INDIVÍDUOS (ADULTOS, JOVENS E PLÂNTULAS) DE Calophyllum brasiliense Camb. (CLUSIACEAE), EM MATA DE GALERIA
}

\section{CRISTINA BORGES KAWAGUICI}

Bióloga

Orientador: Prof. Dr. PAULO YOSHIO KAGEYAMA

Dissertação apresentada à Escola Superior de Agricultura "Luís de Queirož. Universidade de São Paulo, para obtenção do título de Mestre em Ciências. Área de Concentração: Ciências Florestais.

PIRACICABA

Estado de São Paulo - Brasil

Outubro - 1999 


\section{ERRATA}

Pág/Parágrafo/Linha
3/Objetivo $2 / 2$
$5 / 5 / 3$
$9 / 3 / 3$
$24 /-/ 6$
$25 / 1 / 2$
$45 / 2 / 2$
$45 / 2 / 4$
$47 / 2 / 1$
$49 / 1 / 6$
$61 / 1 / 3$
$61 / 1 / 3$
$61 / 2 / 4$
$67 / 3$

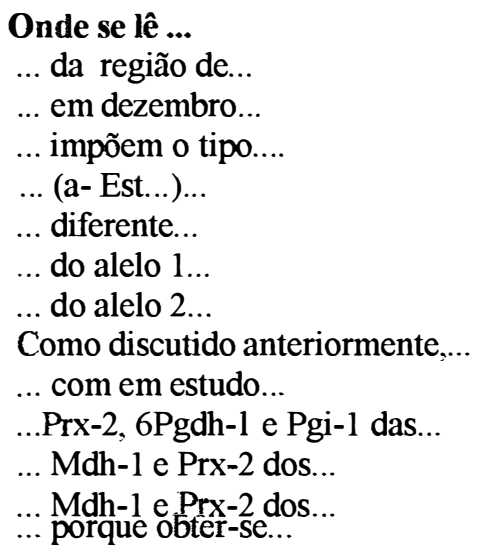

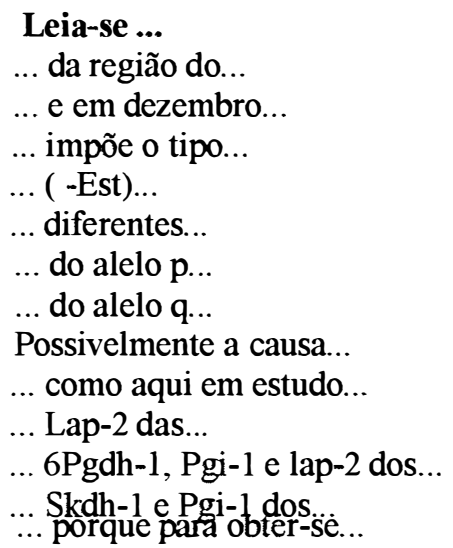

... da região do..

... e em dezembro..

... impõe o tipo...

do alelo $p$

... do alelo q...

Possivelmente a causa..

... como aqui em estudo..

... Skdh-1 e Pgi-1 dos

Pág. 26, título da tabela 2, linha 1

Onde se lê: ... grupos...; Leia -se: ... grupo...

Pág 46, coluna Alelos da tabela 8

Onde se lê: P, Q e R em letra maiúscula; Leia-se: p. q e r em letra minúscula.

Pág. 61, continuação do parágrafo 4

O loco Mdh-1 das plântulas não apresentou em EEW, o que não pôde ser explicado em relação à endogamia gerada por autofecundação e/au acasalamento entre aparentados.

\section{ERRATA DO SUMMARY}

In order to investigate the genetic variability of a common forest species, a population of Calophyllum brasiliense was studied in the gallery forest of the Panga Ecological Station, Uberlândia-MG, Brazil. This is a tree species that occurs only on water saturated soil distributed along the Panga River, the northern limit of station. Three groups of individuals (adults, youth and seedlings) were studied separately.

Analyses of isozyme electrophoresis were carried out for 30 adult individuals, 30 youths and 100 seedlings of Calophyllum brasiliense. It was obtained 22 alleles distributed in 14 enzymatic loci, 8 of which were monomorphic and 6 polymorphyc.

Allelic frequencies varied randomly, which did not allow inferences on the occurrence of selection from each individual group to another.

The Wright's $\mathrm{F}$ among the groups evidenced low genetic divergence between seedlings and youths $(0,0356)$, seedlings and adults $(0,0543)$ and youths and adults, which indicates little drift effects and/or selection.

The diversity indexes estimated for the population revealed a small number of alleles for each locus $\left(A_{\text {seedlins }}=1,71 ; A_{\text {young }}=1,57\right.$ and $\left.A_{\text {adults }}=1,64\right)$. The percentage of polymorphic loci was $P=$ $42,86 \%$, a value that is similar to the values commonly found for rare species. The expected mean heterozigosity was larger than that observed in all groups. The observed values for mean heterozigosity are 0,$191 ; 0,138$ and 0,141 , respectively for seedelings, youths and adults. Hence, most of genetic variability occurs among seedlings. The fixation index was positive for seedlings, youths and adults. This index was higher for the adults, may be because the study area has been colonized recently or the adult individuals are more adapted to the establishment in flooded areas. In the later case, there would be going on a seedling selection for individual establishment ability, which would favor homozygotes.

The estimates of adherence for the Hardy-Weinberg (HWB) balance showed that $50 \%$ of the loci in the seedlings and adults met HWB ratios. All loci in the youth group met HWB ratios. These results suggest that mating is not at random in the population and/or the occurrence of selection or drift.

The results of population effective size $(\mathrm{Ne})$ measurements, demonstrated that as endogamy increases, smaller is the significance of effective size estimates. That estimate allow also inferences on the possible strategies of conservation genetics in situ, seeking recovery of degraded areas. 
Dados Internacionais de Catalogação na Publicação (CIP) DIVISĀO DE BIBLIOTECA E DOCUMENTAÇĀO - Campus "Luiz de Queiroz"/USP

Kawaguici, Cristina Borges

Variaçāo genética em três grupos de individuos (adultos, jovens e plântulas) de Calophyllum brasiliense Camb. (Clusiaceae), em Mata de Galeria / Cristina Borges Kawaguici. - Piracicaba, 1999.

98 p. : il.

Dissertaçāo (mestrado) - Escola Superior de Agricultura Luiz de Queiroz, 1999. Bibliografia.

1. Diversidade genética 2. Floresta tropical úmida 3. Genética de população 4. Izoenzima 5. Umidade do solo I. Título

CDD 634.973163

"Permitida a cópia total ou parcial deste documento, desde que citada a fonte - $O$ Autor" 
Quando você começar seu caminho, vai encontrar uma porta com uma frase - diz o mestre, - Volte e me conte qual é esta frase.

O discípulo se entrega de corpo e alma à sua busca.

Chega um dia em que vê a porta, e volta até o mestre.

- Estava escrito no começo do caminho: isto não é possível diz.

- Onde estava escrito isto, num muro ou numa porta? perguntou 0 mestre.

- Numa porta - respondeu o discípulo.

- Pois coloque a mão na maçaneta e abra.

O discípulo obedece. Como a frase está pintada na porta, também vai se movendo com ela. Com a porta totalmente aberta, ele iá não consegue mais enxergar a frase - e segue adiante. 
À minha mãe, Neusa, por muito do que sou e pela ousadia de ter criado meus irmãos e a mim praticamente sozinha, com amor e determinação, apesar das dificuldades. Aos meus saudosos, pai Fábio e avó Lira (in memorian), por saber que sempre estiveram do meu lado me protegendo, por serem a minha inspiração e pelos "inesquecíveis" momentos de alegria.

DEDICO

Ao meu marido Vinícius, meu companheiro em todas as situações, que me auxiliou em todas as fases deste trabalho, me incentivou, mas principalmente me deu tranqüilidade e carinho nos

momentos mais dificeis.

OFEREÇO 


\section{AGRADECIMENTOS}

À Deus, pela proteção e por guiar todos os passos da minha caminhada;

Ao Prof. Dr. Paulo Yoshio Kageyama, pela orientação, pelos grandiosos ensinamentos e pela oportunidade na realização desta importante etapa de minha vida;

Ao Prof. Dr. Ivan Schiavini, acima de tudo uma grande pessoa, pela coorientação e por mais uma vez transmitir com brilhantismo seus conhecimentos em princípios e conceitos de ecologia;

Ao Prof. Dr. Roland Vencovsky, pelo aceite em participar da banca de defesa e pelas valiosas sugestões a repeito deste trabalho;

Aos membros da banca de qualificação, Prof. Dr. Ricardo Rodrigues, Prof. Dr. Antônio Natal e Prof. Ms. Flávio Gandara, pelas sugestões, discussões e críticas, que foram colocadas de forma agradável durante a análise prévia deste trabalho;

Ao colega e coautor Alexandre Magno Sebbenn, que dedicou boa parte de seu precioso tempo para me ajudar, dando sugestões, ensinamentos e auxílio, que foram essenciais para concretização deste trabalho;

Aos colegas de pós graduação do LARGEA, Cristina Lacerda, Helena Maltez, Eduardo Seoane e Flávio Gandara pelas valiosas sugestões e paciência. Aos técnicos do LARGEA, Elza e Gelson, pela contribuição no laboratório e pelo agradável convívio;

À grande amiga, Andréa Vanini, pelos valiosos conselhos e pela valiosa amizade; 
Às amigas Andréa, Kátia, Alessandra e Cristiana e ao amigo Alexandre por cederem moradia em Piracicaba e pelos agradáveis momentos de convivência;

Aos colegas de pós graduação, pelos curtos mais agradáveis momentos de diversão;

À Universidade Federal de Uberlândia (Depto. de Biociências), pela "carona" até a reserva, e ao Prof. Paulo E. A. Oliveira pelo interesse no meu trabalho e esclarecimento de minhas dúvidas;

Ao Júlio Rezende e Hubert Rocha, que auxiliaram no trabalho de campo;

À FUTEL, na pessoa do Sr. Lione Tannús Gargalhone, pelo auxílio, incentivo, apoio e por acreditar em mim, e aos funcionários do Parque do Sabiá, por compreenderem a minha ausência;

À Denise Cunha, pela leitura e correção do summary;

À minha família, mãe, irmãos, avô, sobrinho e sogros, pelo apoio, amor, carinho e incentivo, acima de tudo;

À todas as pessoas que direta ou indiretamente contribuíram para término deste trabalho;

À FAPESP, pela concessão de bolsa, de acordo com o processo 96/03655-0. 
SUMÁRIO

Página

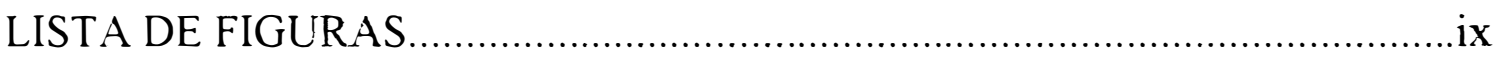

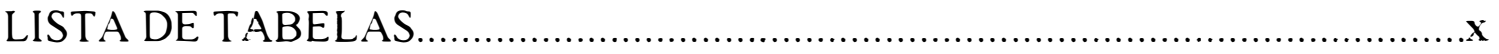

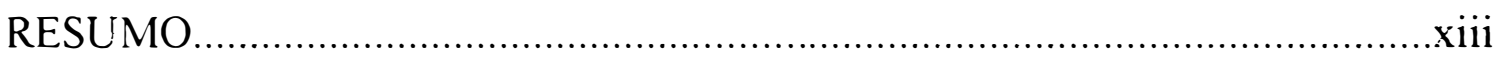

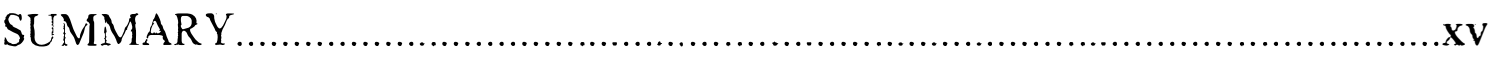

1 INTRODUÇÃO

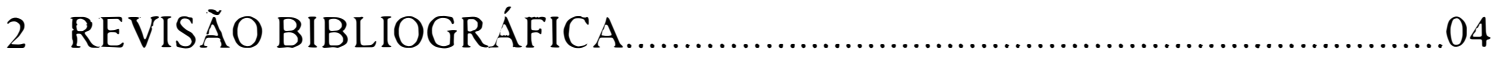

2.1 A Espécie Calophyllum brasiliense Camb.................................................

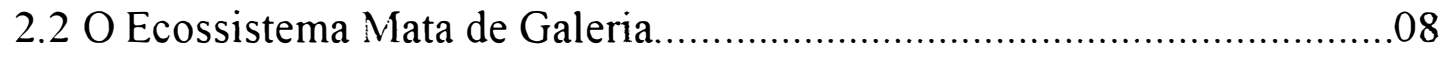

2.3 Estrutura de Tamanho Populacional........................................................ 10

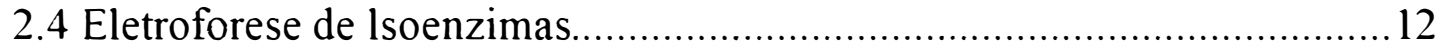

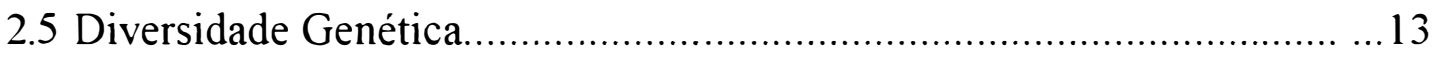

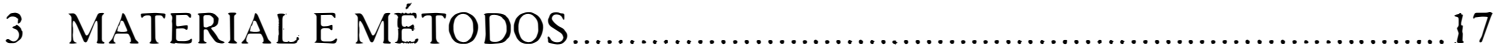

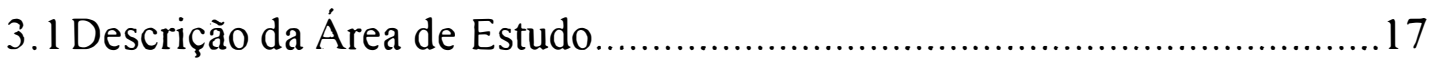

3.2 Determinação dos Grupos a serem Analisados na População....................19

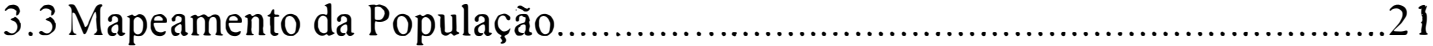

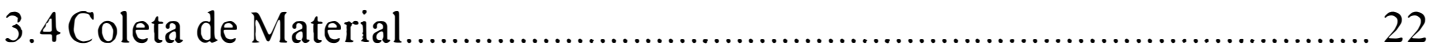

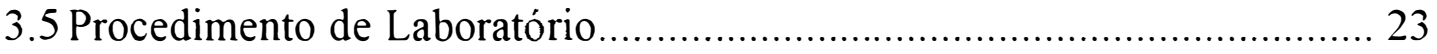

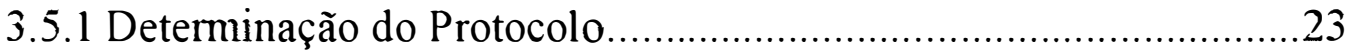

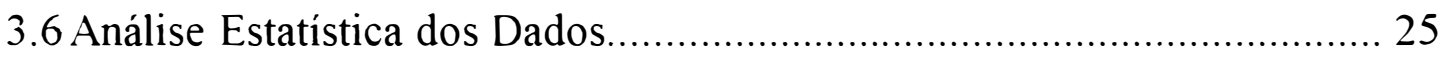

3.6.1 Análise das Freqüências Alélicas dos Grupos..............................25

3.6.2 Diferenças nas Freqüências Alélicas...........................................25

3.6.3 Divergência Genética entre os grupos de Indivíduos $\left(\hat{f}_{S T}\right) \ldots \ldots \ldots \ldots .28$

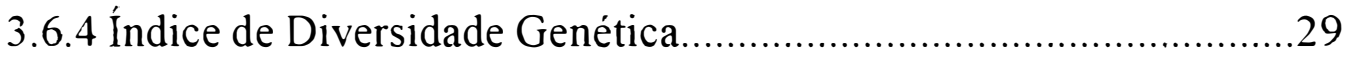

a) Heterozigosidade Média Observada....................................... 29 


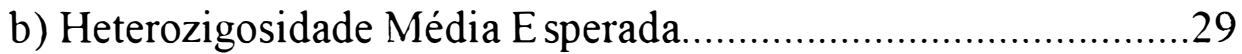

c) Número Médio de Alelos por Loco............................................30

d) Porcentagem de Locos Polimóficos...........................................30

e) Índice de Fixação de Wright ......................................................30

3.6.5 Aderência ao Equilibrio de Hardy - Weinberg................................31

3.6.6 Análise de Estrutura Genética entre os Grupos..............................32

3.6.6.1 Análise de Variância de Freqüência Alélicas........................32

a) Análise Individual para cada Grupo.............................................

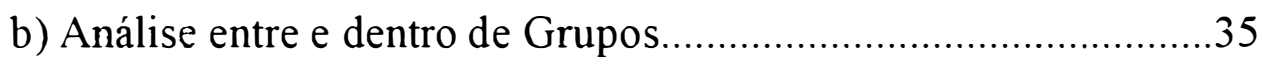

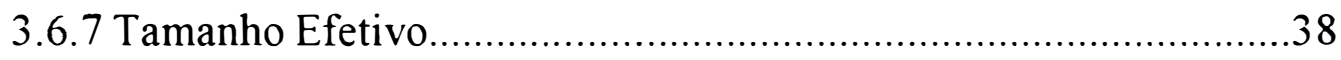

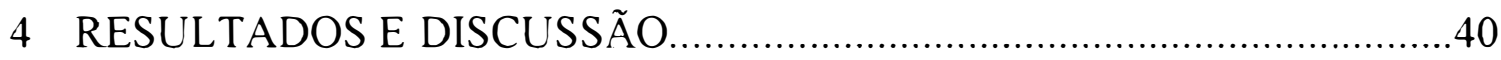

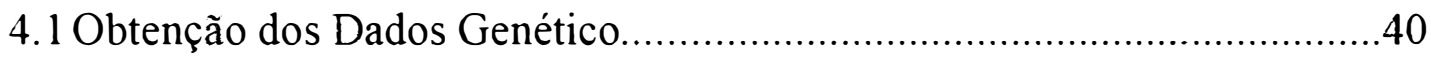

4.1.1 Procedimento de Eletroforese.de lsoenzimas................................40

4.1.2 Interpretação Genética dos Zimogramas........................................42

4.2 Análise das Frequências Alélicas dos grupos ...........................................45

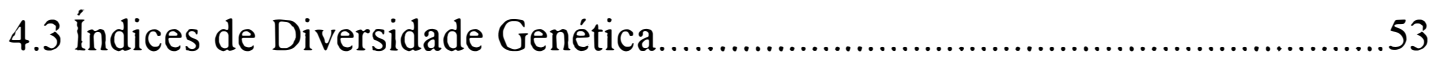

4.4 Aderência ao Equilibrio de Hardy - Weinberg.........................................58

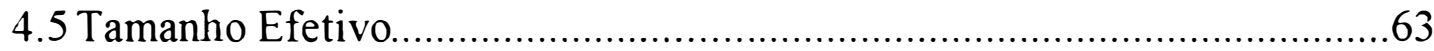

5 CONCLUSÕES

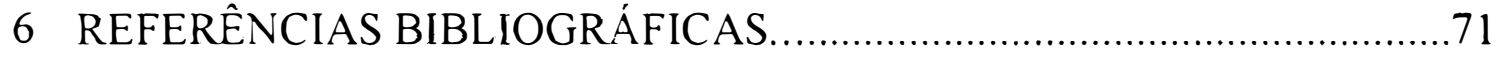

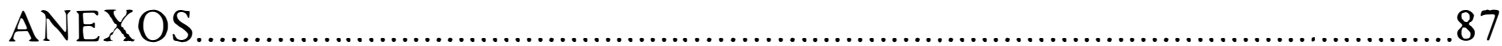




\section{LISTA DE FIGURAS}

Página

1 Aspectos da árvore, flor, semente, tronco e madeira de Calophyllum brasiliense Camb. Piracicaba, ESALQ/USP, 1999. (Foto: LORENZI, 1992)

2 Mapa de localização da Estação Ecológica do Panga, no município de Uberlândia, MG. Destaque para a cobertura Vegetal e localização da área de estudo. (adaptado de SCHIAVINI, 1992)

3 Mapeamento da Mata de Galeria, em detalhe sua delimitação............

4 Interpretação Genética dos Zimogramas dos Sistemas Enzimáticos Polimórficos Utilizados no Estudo de Plântulas, Jovens e Adultos de uma População de Calophyllum brasiliense Camb. na Estação Ecológica do Panga (Uberlândia - MG). Piracicaba - SP, ESALQ/USP, 1999 


\section{LISTA DE TABELAS}

Página

1 Solução de extração utilizada em C. brasiliense Camb. Piracicaba - SP, ESALQ/USP, 1999.

2 Freqüências alélicas para cada grupos, para a média dos grupos e tamanho da amostra em um loco com dois alelos. ESALQ/USP. 1999.. 26

3 Freqüências alélicas observadas e esperadas em diferentes grupos. ESALQ/USP. 1999.

4 Freqüências genotípicas observadas e esperadas em diferentes grupos. ESALQ/USP. 1999.

5 Esquema da análise de variância de freqüência alélicas no modelo hieráquico desbalanciado para adultos, jovens e plântulas de $C$. brasiliense, em uma população, considerando a espécie como dióca. Piracicaba, ESALQ/USP, 1999.

6 Esquema da análise de variância de freqüência alélicas no modelo hieráquico desbalanciado para adultos, jovens e plântulas de $C$. brasiliense, em uma população, considerando a espécie como hermafrodita. Piracicaba, ESALQ/USP, 1999.

7 Enzimas, sistema de tampão gel/eletrodo e número de locos observados na determinação do protocolo. Piracicaba, ESALQ/USP, 1999.

8 Freqüências alélicas para 6 locos isoezimáticos polimórficos detectados 
e teste de $\mathrm{X}^{2}$ de contingência em $C$. brasiliense. (ns: não significativo;*:5\%; **: 1\%). Piracicaba, ESALQ/USP. 1999

9 Estimativa de divergência genética ( $\hat{F}_{\text {ST }}$ ) entre Adultos e Jovens, Jovens e Plântulas e Adultos e Plântulas, de C. brasiliense, a partir de 8 locos enzimáticos polimórficos. Piracicaba - SP, ESALQ/USP, 1999.

10 Frequências genotípicas para 6 locos isoezimáticos polimórficos detectados e teste $\mathrm{X}^{2}$ de contingência em $C$. brasiliense. (ns: não significativo:*:5\%; **: 1\%). Piracicaba, ESALQ/USP. 1999

11 Variabilidade genética de uma população de C. brasiliense com base em 14 locos e 8 sistemas enzimáticos (os valores entre parênteses equivalem ao erro padrão da média). Piracicaba, ESALQ/USP, 1999....... 54

12 Índice de Fixação $(\hat{f})$ para 3 grupos de $C$. brasiliense, locos polimórficos. Piracicaba, ESALQ/USP, 1999 .............................................. 55

13 Verificação da aderência das estimativas encontradas para 6 locos polimórficos ao modelo do Equilíbrio de Hardy - Weinberg, através dos testes do $\chi^{2}$ para o grupo de plântulas de $C$. brasiliense. Piracicaba - SP, ESALQ/USP, 1999

14 Verificação da aderência das estimativas encontradas para 6 locos polimórficos ao modelo do Equilíbrio de Hardy - Weinberg, através dos testes do $\chi^{2}$ para o grupo de jovens de $C$. brasiliense. Piracicaba - SP,

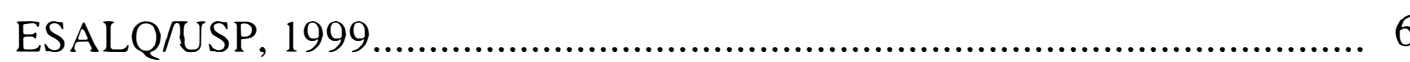


15 Verificação da aderência das estimativas encontradas para 6 locos polimórficos ao modelo do Equilíbrio de Hardy - Weinberg, através dos testes do $\chi^{2}$ para o grupo de adultos de $C$. brasiliense. Piracicaba - SP,

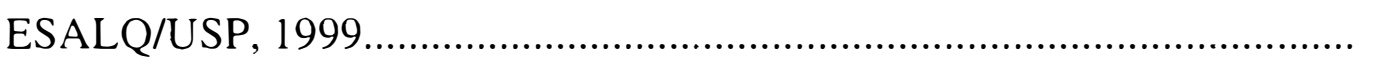

16 Teste de equilíbrio de endogamia de Wright (EEW), para o loco Mdh1 de plântulas de C. brasiliense. ESALQ/USP, 1999

17 Componentes de variâncias a nível de média de locos para todos os Grupos, Plântulas, Jovens e Adultos, e $\hat{N}_{\cdot}, \hat{N}_{c} \%$ e $\hat{f}$. Considerando C. brasiliense como hermafrodita. Piracicaba- SP, ESALQ/USP. 1999.

18 Simulação do tamanho efetivo de $C$. brasiliense, considerando as proporções sexuais de machos $(\mathrm{M})$ e fêmeas $(\mathrm{F})$ diferentes $[1$ macho para 1 fêmea (1:1), 1 macho para 2 fêmeas (1:2) e 1 macho para 3 fêmeas (1:3)]. Piracicaba- SP, ESALQ/USP, 1999. 


\title{
VARIAÇÃO GENÉTICA EM TRÊS GRUPOS DE INDIVÍDUOS (ADULTOS, JOVENS E PLÂNTULAS) DE Calophyllum brasiliense Camb. (CLUSIACEAE), EM MATA DE GALERIA
}

\author{
Autora: CRISTINA BORGES KAWAGUICI \\ Orientador: Prof. Dr. PAULO YOSHIO KAGEYAMA
}

\section{RESUMO}

Com intuito de investigar a variabilidade genética de uma espécie comum, mas com restrição ambiental, foi estudada uma população de Calophyllum brasiliense, espécie que ocorre apenas em áreas onde existe saturação hídrica do solo, em 3 grupos de indivíduos (adultos, jovens e plântulas). A população estudada está situada na mata de galeria da Estação Ecológica do Panga (Uberlândia- MG), distribuída ao longo do Córrego do Panga que constitui o limite norte da reserva.

A partir da análise de eletroforese de isoenzimas, foram analisados 30 indivíduos adultos, 30 indivíduos jovens e 100 plântulas de C. brasiliense. Obteve-se 22 alelos distribuídos entre 14 locos isoenzimáticos, sendo que 8 eram monomórficos e 6 polimórficos.

As frequiências alélicas entre os grupos oscilaram de forma aleatória, o que não permitiu inferir sobre ocorrência de seleção de um grupo de indivíduos para outro.

O $\hat{F}_{\text {ST }}$ entre os grupos evidenciou divergência genética significativa entre plântulas e jovens $(0,0356)$, plântulas e adultos $(0,0543)$ e jovens e adultos $(0,0759)$, indicando pouco efeito de deriva e/ou seleção. 
Os índices de diversidade estimados para a população revelaram baixo número de alelos por loco ( $A_{\text {plântulas }}=1,71 ; A_{\text {jovens }}=1,57$ e $\left.A_{\text {adultos }}=1,64\right)$. A porcentagem de locos polimórficos foi de $\mathrm{P}=42,86 \%$; esse valor é semelhante aos valores comumente encontrados para as espécies raras. A heterozigosidade média esperada foi maior que a observada em todos os grupos; os valores de heterozigosidade média observada são respectivamente para plântulas, jovens e adultos de 0,$191 ; 0,138$ e 0,141 , portanto, a maior parte da variabilidade genética se encontra dentre do grupo de plântulas. O índice de fixação $(\hat{f})$ foi positivo para plântulas $(0,084)$, jovens $(0,264)$ e adultos $(0,372)$, mostrando-se mais pronunciado nos adultos. Esse alto índice de fixação pode estar ocorrendo nesse grupo, devido a área de estudo ter sido colonizada recentemente ou, então os indivíduos adultos estão mais adaptados ao estabelecimento em áreas alagadas, desta forma, estaria havendo seleção de plântulas para o estabelecimento de indivíduos adultos, em favor de homozigotos.

$\mathrm{O}$ teste de aderência de equilíbrio de Hardy-Weinberg (EHW) evidenciou que $50 \%$ dos locos nas plântulas e nos adultos encontravam-se aderidos a suas proporções. O grupo de jovens encontrava-se nas proporções do EHW. Estes resultados indicam que os acasalamentos não são totalmente aleatórios na população e/ou a presença de seleção ou deriva.

Os resultados de tamanho efetivo $\left(\hat{N}_{\epsilon}\right)$ demonstraram que, quanto maior a endogamia (adultos), menor é a representatividade do tamanho efetivo. Essa estimativa também inferiu sobre as possíveis estratégias de conservação genética in situ, visando recuperação de áreas degradadas. 


\title{
GENETIC VARIATION IN THREE GROUPS OF INDIVIDUALS \\ (ADULTS, YOUNTHS AND SEEDLINGS) OF Calophyllum brasiliense \\ Camb. (CLUSIACEAE), IN GALLERY FOREST
}

\author{
Author: CRISTINA BORGES KAWAGUICI \\ Adviser: PAULO YOSHIO KAGEYAMA, Phd.
}

\section{SUMMARY}

With intention of investigating the genetic variability of the usual species, with environmental restriction, it was studied a Calophyllum brasiliense population, species that just happens in areas where water saturation of the soil exists, in three groups of individuals (adults, youths and seedlings). The studied population is placed in the forest of gallery of the Ecological Station of Panga, distributed along the river of the Panga, that constitutes the north limit of the reservation.

Starting from the analysis of isozyme electrophoresis, 30 adult individuals were studied, 30 yuong and 100 seedlings of Calophyllum brasiliense. It was obtained 22 alleles distributed in 14 loci enzymatic, and 8 were monomorphic and 6 polymorphyc.

The frequencies allelics was aleatory, what didn't allow interfervencein the occurrence of selection in the individual group for another.

The Wright's $F$ among the groups evidenced low genetic divergence between seedlings and youths $(0,0356)$, seedlings and adults $(0,0543)$ and yuongs and adults, that indicates little drift effects and or selection. 
The dear diversity indexes for population revealed low alleles nu. ser for loci $\left(A_{\text {seedlins }}=1,71 ; A_{\text {young }}=1,57\right.$ and $\left.A_{\text {adults }}=1,64\right)$. The percentage polymorphic loci was $\mathrm{P}=42,86 \%$, that value is commonly similar to the alues found to the rare species. The expected medium heterozigosity was more large than that observed in all the groups, the values observed medium heterozigosity are respectively for seedelings, youths and adults 0,$191 ; 0,138$ and 0,141 , the more part of genetic variability meets inside of the seedlings group. The fixation index was positive for seedlings,youths and adults, this value was more pronounced in the adults, it's can be occur decause the study area have been colonized recently or then, the adult individuals are more adapted to the establishment in flooded areas, this way, it would be having seedlings selection for the individuals estabilishment, to favour homozygotes.

The estimates of adherencefor the Hardy-Weinberg balance didn't evidence differences among the groups, some loci are in balance, others dont's.

The results of effective size, demonstrated that how many large the endogamic, small is the value of the effective size. That estimate also intervence in the possible strategies of conservation genetics in situ, seeking recovery of degraded areas. 


\section{INTRODUÇÃO}

O sudeste brasileiro, assim como o resto do País, vem há muito sofrendo uma degradação contínua de suas florestas naturais, causada nas ultimas décadas por atividades antrópicas, principalmente agropastoris. No geral, as florestas naturais estão hoje restritas a pequenas manchas, ainda livres dos domínios da agricultura.

As matas de galeria constituem um importante ecossistema, possuindo uma abundante diversidade de espécies vegetais e animais. Na região do cerrado brasileiro, apesar de representar pequena porção, destaca-se pela sua riqueza, diversidade genética e pelo seu papel na proteção dos recursos hídricos, edáficos, fauna silvestre e aquática. Essas matas, constituem um potencial refúgio para fauna, principalmente na estação seca, quando a quantidade de alimento, abrigo e umidade ficam escassos. As matas de galeria são importantes também para a manutenção do patrimônio genético de diversas espécies vegetais e funcionam como ccrredores para dispersão de espécies florestais à longas distâncias.

Pouco se conhece sobre a estrutura e funcionamento desses ambientes florestais, principalmente na região do Triângulo Mineiro. Desta forma, existe a necessidade de estudos intensivos desses ecossistemas, a fim de escolher corretamente as estratégias de manejo e conservação a serem implantadas. 
Neste sentido, são raros os casos de espécies estudadas no ponto de vista genético, sendo estes indispensáveis à exploração racional, à recuperação e, principalmente, à conservação dos recursos da floresta tropical. Estes estudos são importantes para que não ocorra a perda de sua diversidade genética natural, permitindo que suas populações mantenham-se vivas e reprodutivas ao longo dos tempos, no ciclo evolutivo da seleção natural.

Uma das principais ferramentas destes estudos consiste no conhecimento do sistema reprodutivo, do fluxo gênico intra e inter populacional, de distribuição espacial dos indivíduos e, principalmente, da distribuição da variação genética entre e dentro de populações das espécies que compõem as comunidades em estudo (Kageyama, 1987).

Utilizando-se da técnica de isoenzimas, autores como Hamrick et al. (1979), Hamrick (1983, 1987), Hamrick \& Loveless (1986, 1989), Hamrick \& Murawski (1991), Loveless \& Hamrick (1987), Buckley et al. (1988) para Bertholletia excelsa, Moraes (1993.) para Myracrodruon urundeuva, Gandara (1996) com Cedrela fissilis Veel., Liengsiri et al. (1995) com Pterocarpus macrocarpus Kurz., dentre outros, têm e studado a estrutura genética de espécies arbóreas de florestas tropicais.

Neste contexto, propõe-se estudar uma população de Calophyllum brasiliense Camb.(guanandi), em Mata de Galeria, na Estação Ecológica do Panga (Uberlândia-MG), usando-se para tal o método de eletroforese de isoenzimas. Pretendeu-se, obter informações sobre a estrutura genética de 3 grupos de indivíduos dessa população (adultos, jovens e plântulas), verificando se o conjunto de adultos, jovens e plântulas podem ser divergentes geneticamente, e se um processo de seleção está ocorrendo.

Infelizmente, não se têm dados demográficos de longo prazo, ou com indivíduos de todas as faixas etárias bem estudados. Dessa forma, acredita-se que esses dados poderão inclusive dar contribuição relevante a essa discussão. 
Assim sendo, considera-se que este estudo possa servir como modelo para espécies de ampla diștribuição em ambiente restrito onde há saturação hídrica, sendo muito comum nesses ambientes, igualmente importantes e similares ao guanandi. Essa pergunta contribuirá para o estabelecimento de estratégias de conservação dessas comunidades, assim como inferir corretamente sobre os métodos de manejo a serem aplicados para a conservação da floresta tropical.

A partir do exposto pretendeu- se atingir com este trabalho os seguintes objetivos:

1- Definir o protocolo para o estudo de eletroforese de isoenzimas de C. brasiliense;

2- Quantificar a variabilidade genética de uma população de $C$. brasiliense em mata de galeria da região de Triângulo Mineiro;

3- Comparar a diversidade genética em 3 grupos de indivíduos (adultos, jovens e plântulas) de C. brasiliense. 


\section{REVISÃO BIBLIOGRAFICA}

\subsection{A Espécie Calophyllum brasiliense Camb.}

Vulgarmente conhecida como guanandi, olandi, jacareúma ou mangue, $C$. brasiliense Camb. (Figura l) é uma espécie vegetal pertencente à Família CLUSIACEAE e chega a atingir cerca de $20-25 \mathrm{~m}$ de altura e $50-70 \mathrm{~m}$ de diâmetro. No Brasil, a família está representada por 21 gêneros e 183 espécies, com ampla distribuição, da região Amazônica até o norte de Santa Catarina (Barroso, 1978; Lorenzi, 1992).

Os indivíduos de $C$. brasiliense são arbóreos, apresentando copa larga, tronco reto e cilíndrico; a casca é dura, escura e muito fissurada. As folhas são opostas, de disposição cruzada, cor verde- escura luzente, coriáceas e glabras, apresentam numerosas nervuras laterais muito próximas entre si, paralelas, de aspecto muito característico, estas têm aproximadamente $10-13 \mathrm{~cm}$ de comprimento por $5-6 \mathrm{~cm}$ de largura. As flores são brancas e vistosas, polígamas, reunidas em inflorescência racemiformes. Os frutos são drupas globosas, com 1,5-2cm de diâmetro, bastante duros quando secos e seus embriões são globosos, com cotilédones muito crassos, plano convexos e rostilo quase imperceptível. Este é de cor amarelada e, se for feito um corte longitudinal, aparecerá subfusiformes, cinturado, de radícula e plúmula cônicas, entre os cotilédones globosos e unidos (Schvastsman, 1979; Reitz et al., 1978; Lorenzi, 1992; Albuquerque, 1993). 
Considerada a primeira madeira de lei do Brasil, C. brasiliense é muito utilizada na indústria madeireira, principalmente na fabricação de embarcações (Pio Correa, 1931; Lorenzi, 1992). Sua madeira é moderadamente pesada, fácil de lavrar e serrar, o talhe é macio e de belo efeito quando envernizada, com durabilidade moderada (Pio Correa, 1931). Sua casca pode ser utilizada como estopa para calafetagem e a "goma resina" dela retirada pode ser usada como emplasto de aplicação veterinária (Pio Correa, 1931).

Segundo Schvastsman (1979), trata-se de uma espécie tóxica, produzindo, a partir de ferimentos do tronco, látex leitoso fortemente irritante que causa manchas escuras na pele.

C. brasiliense é característico e exclusivo das florestas pluviais, localizadas sobre solos úmidos e brejosos. É capaz de crescer virtualmente dentro da água e até em áreas de mangue (Lorenzi,1992). Apresenta um caráter perinifólio, com queda de suas folhas pouco evidente, o que está relacionado com a condição hídrica do solo. Os primórdios foliares surgem ainda na estação seca e a brotação desencadeia a floração (Marques, 1994).

A floração da espécie ocorre entre os meses de outubro e novembro (Marques, 1994). Esta grande produção de flores, num intervalo de tempo relativamente pequeno, pode possibilitar a atração de uma diversidade maior de polinizadores.

Segundo Carvalho (1994), o guanandi apresenta floração variável, em virtude de sua ampla dispersão: floresce de setembro a outubro no Distrito Federal, de novembro a junho em São Paulo, em dezembro na Paraíba. Os frutos maduros apareceram disponíveis de maio a junho no Distrito Federal, de junho a outubro em São Paulo, de junho a fevereiro no Panamá e de julho a novembro em Santa Catarina. 

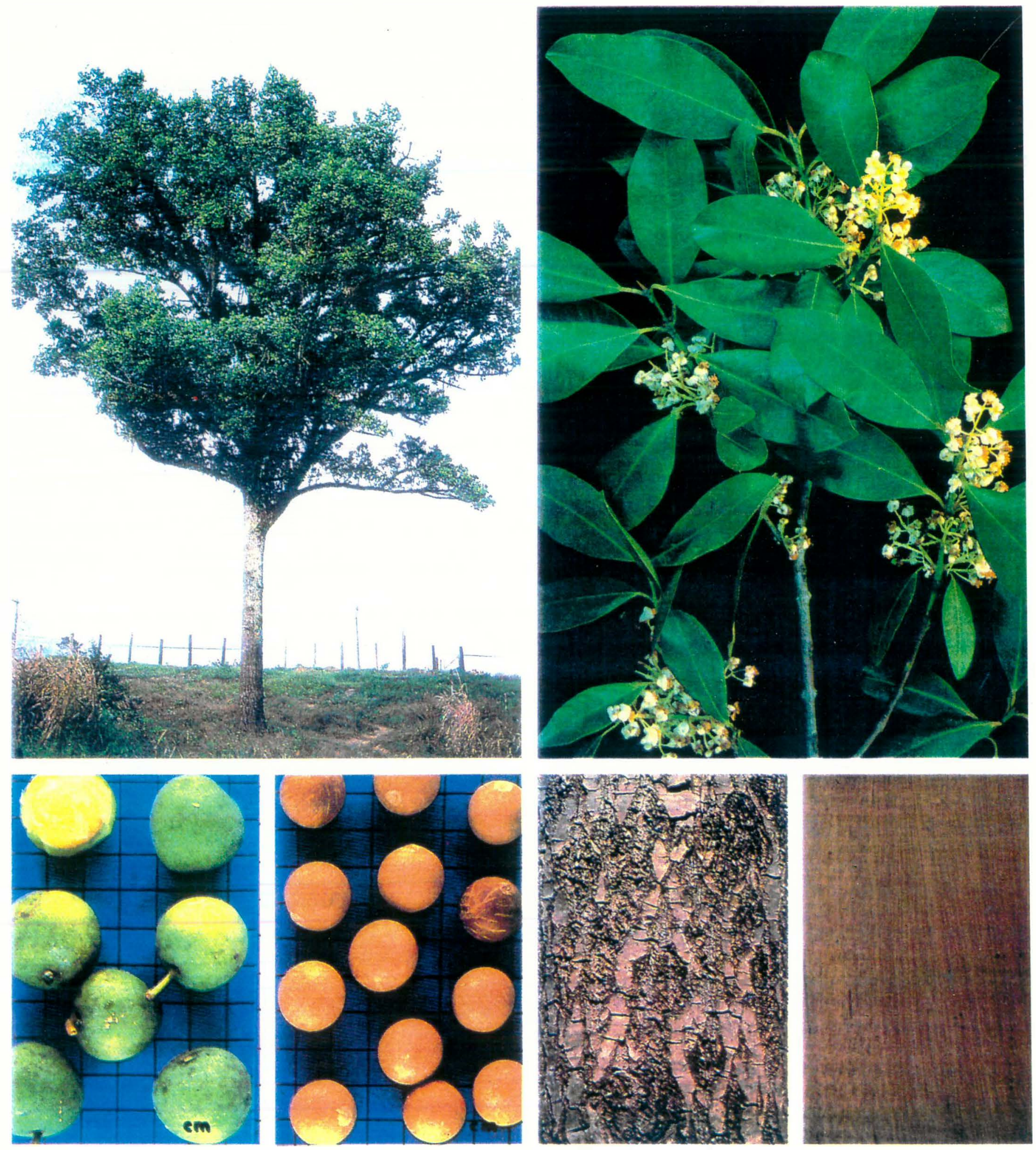

Figura 1. Aspectos da árvore, flor, semente, tronco e madeira de Calophyllum brasiliense Camb. Piracicaba, ESALQ/USP, 1999. (Foto: Lorenzi, 1992). 
Aparentemente, a espécie apresenta um sistema reprodutivo complexo, pois possui flores hermafroditas e masculinas em indivíduos separados ou em diferentes proporções num mesmo indivíduo (Marques, 1994). A espécie é considerada para uns como sendo hermafrodita e para outros como dióica, sendo a parte masculina das flores hermafroditas não funcionais (Oliveira, informações pessoais)

A frutificação é a fenofase mais longa e os frutos estão disponíveis nas árvores por mais ou menos 10 meses. Produz quase todos os anos grande quantidade de sementes viáveis (Lorenzi, 1992; Marques, 1994; Kawaguici, 1994).

A dispersão do guanandi é ampla (Lorenzi, 1992). Os frutos são dispersos pela água (hidrocoria), por morcegos (quiropterocoria), podendo ainda cair sob a copa da árvore-mãe (autocoria) (Marques, 1994). Esta diversificação no modo de dispersão proporciona uma variedade de microambientes para a germinação das sementes e o estabelecimento das plantas.

A distribuição de diâmetro e altura dos indivíduos de $C$. brasiliense dentro de uma população é do tipo "J" invertido, que indica uma população estável, com taxas constantes de mortalidade e recrutamento (Marques, 1994; Kawaguici, 1994).

A espécie apresenta distribuição espacial do tipo agregada, sendo que essa condição pode ser influenciada por dois fatores. Primeiro, pela forma de dispersão dos frutos, que apresenta vários microambientes diversificados para a germinação das sementes. Isto faz com que a agregação dos indivíduos próximos à planta-mãe, ou nos "poleiros" onde os morcegos carregam os frutos para se alimentarem, fique diluída pela possibilidade de movimentação horizontal dos diásporos, promovida pela corrente de água (Marques, 1994). O segundo fator que influência a distribuição dos indivíduos é a condição hídrica 
do local. A capacidade de $C$. brasiliense se desenvolver normalmente em locais de saturação hídrica faz com que a espécie tenha vantagens sobre outras espécies, o que representa uma distribuição concentrada em regiões mais úmidas. Estas observações já foram registradas para esta espécie (Fischer, 1990; Schiavini, 1992; Marques, 1994 e Kawaguici, 1994).

\subsection{O Ecossistema Mata de Galeria}

A mata de galeria é uma floresta mesófila, de qualquer grau de deciduidade, que orla em um ou nos dois lados de um curso de água, em uma região onde a vegetação do interflúvio não é uma floresta contínua (Mantovani, 1989).

A transição entre os ambientes aquático e terrestre faz com que os mesmos apresentem características próprias que lhes conferem uma complexidade ecológica (Aciesp, 1987; Nilsson, 1992). Esse ecótono, no qual estão incluídas as formações florestais ocorrentes ao longo de rios, possui distribuição ampla, sendo evidenciado em regiões de domínio de formações abertas e distinto apenas floristicamente em áreas onde há predomínio de formações florestais (Troppmair \& Machado, 1974; Aciesp, 1987; Rodrigues, 1989).

Apesar da controvérsia na utilização dos termos mata "de galeria", "ciliar" ou "ripária" (Troppmair \& Machado, 1974; Mantovani et al., 1989 ; Rodrigues, 1992), a importância da vegetação existente ao longo dos cursos de água tem sido ressaltada em vários trabalhos (Rodrigues, 1992; Aidar, 1992). Entretanto o termo "Mata Ciliar" tem abrangência mais ampla do que o termo "Mata de Galeria". Mata Ciliar tem sido utilizado para a vegetação florestal

ocorrente em rios de grande largura, onde a copa das árvores de ambas as 
margens não se tocam, permitindo a entrada direta e a influencia da luz sobre a vegetação mais próxima ao rio. Já nas Matas de Galeria, as copas das árvores de ambas as margens formam a galeria propriamente dita, o que permite condições ambientais, sobretudo luz e temperatura, diferenciadas para o corpo d'água e para a vegetação das margens do rio (Ribeiro \& Schiavini, 1998).

A função hidrológica das Matas de Galeria está associada à estabilização das áreas ribeirinhas, ao controle dos ciclos de nutrientes da bacia hidrográfica, à manutenção da qualidade da água, além de propiciar a sobrevivência dos organismos aquáticos e ribeirinhos (Lima, 1989).

As Matas de Galeria atuam como barreira física, regulando os processos de troca entre os sistemas terrestre e aquático, desenvolvendo condições propícias à infiltração (Kageyama, 1986; Lima, 1989). Sua presença reduz significativamente a possibilidade de contaminação dos cursos d'água por sedimentos, resíduos de adubos, defensivos agrícolas, conduzidos pelo escoamento superficial da água no terreno (Resende, 1998).

Pela própria natureza do ecossistema, as Matas de Galeria encontram-se em transição quanto ao solo e os gradientes de umidade dele. Este último geralmente impõem o tipo de vegetação, indicando espécies adaptadas, tolerantes ou indiferentes a solos encharcados ou sujeitos a inundações temporárias (Kageyama et al., 1989).

Essas matas são influênciadas principalmente pelas características do rio e da topografia local, que determinarão a freqüência e duração das inundações (Rodrigues, 1989, 1992). Estes fatores são muito variáveis, que formam um verdadeiro mosaico de situações (Joly, 1986) e que atuará na seleção e distribuição das espécies arbóreas, resultando em uma estrutura de composição florística bastante heterogênea (Nilsson et al., 1988; Mantovani et al., 1989; Rodrigues, 1992). 
Se a Mata de Galeria for considerada como aquela área diretamente influenciada por flutuações do lençol freático, observa-se o predomínio de poucas espécies, o que pode ser considerado como uma tendência normal dessas formações florestais devido às especificidades deste ambiente. Essas condições locais favorecem o estabelecimento de certas hegemonias na vegetação, por meio de espécies preferencias que normalmente exibem ampla dominância local. Esse tipo de vegetação possui mais de uma centena de espécies arbóreas por hectare, com baixa densidade por hectare para cada espécie. Essa variabilidade de espécies é acompanhada de intensa relação da vegetação com insetos, pássaros e mamíferos responsáveis pelo transporte de pólen e sementes (Kageyama, 1986).

\subsection{Estrutura de Tamanho Populacional}

A estrutura de tamanho de uma população pode demonstrar a sua regeneração do passado e do presente (Knowles \& Grant, 1983; Agren \& Zackrisson, 1990).

Segundo Daubenmire (1972), em uma comunidade climácica espera-se encontrar uma série completa de classes de tamanho para cada uma das espécies que compõe o ecossistema, posto que, para cada planta que morre ou envelhece, uma outra, imediatamente mais nova, deve estar disponível para substituí-la. Quando uma série é interrompida ou truncada, o ciclo de vida não está sendo completado e a espécie, geralmente, não pode ser considerada como em equilíbrio no ambiente. Portanto, populações em equilíbrio apresentam histogramas de freqüências de classes de diâmetro como uma série geométrica decrescente (Martins, 1991). 
Algumas populações de plantas mostram uma distribuição de altura e diâmetro com predominância de indivíduos nas classes menores e poucos nas maiores (Solbrig, 1981). Esta distribuição pode ser representada por uma curva do tipo "J invertido", que indica uma população estável, com taxas constantes de mortalidade e recrutamento (Hett \& Loucks, 1976; Silvertown, 1987; Agren \& Zackrisson, 1990).

Segundo Weiner (1985), o padrão "J invertido" é explicado por uma interferência dos indivíduos adultos sobre os mais jovens, com desvio de recursos para os primeiros. Webb et al. (1972) sugeriram ainda que a presença de muitas plântulas e o rápido crescimento em condições apropriadas resultariam nesta distribuição. A variação no ciclo reprodutivo com o decorrer do tempo também pode ter grande influência na estrutura de tamanho de uma população (Ramirez \& Arroyo, 1990).

Este padrão de distribuição já foi relatado por vários autores em árvores de regiões tropicais e, no Brasil, destacam-se os trabalhos com Emmotum nitens (Moreira, 1987), Kielmeyera coriacea (Oliveira et al. 1989), em áreas de cerrado, Pithecolobium racemosum (Leite et al. 1982) na Amazônia, Euterpe edulis (Silva, 1991) em floresta semidecídua, Inga affins (Lieberg, 1990), Centrolobium tomentosum (Aidar, 1992), Copaifera langsdorffii (Leite \& Salomão, 1992; Resende, 1994) e em Calophyllum brasiliense (Marques, 1994; Kawaguici, 1994) em mata ciliar/ galeria.

Se o modelo "J invertido" representar a realidade, uma menor freqüência nas classes inferiores deve indicar problemas na regeneração, tais como: deficiência na população e condições inadequadas para o estabelecimento de plântulas (Maltez, 1997).

Janzen (1970) e Connell (1971) propõem que a sobrevivência dos indivíduos de uma população podem estar relacionados com fatores 
influenciados pela densidade ou pela mortalidade associada à distância entre plântula e árvore mãe.

Em populações de plantas, a sobreposição de gerações, através da existência concomitante de indivíduos reprodutivos de diversas classes de tamanho (diversas idades), pode ter importantes implicações sobre a estrutura genética dessas populações, permitindo fluxo gênico entre indivíduos que não se cruzariam caso não houvesse tal sobreposição (Maltez , 1997).

\subsection{Eletroforese de Isoenzimas}

As técnicas de eletroforese de isoenzimas são de grande utilidade para a obtenção de informação genética referente a indivíduos de populações naturais. As enzimas e proteínas de muitos organismos mostram uma grande variação em sua mobilidade eletroforética entre indivíduos.

A eletroforese consiste na migração de moléculas ionizadas (proteínas e aminoácidos) em um campo elétrico, de acordo com suas cargas elétricas e pesos moleculares. A migração é no sentido do elétrodo de sinal contrário ao seu (Alfenas et al., 1991).

Em comparação com ensaios de progênies de campo, a eletroforese possui vantagem, pois os estudos podem ser desenvolvidos em pouco tempo, com custo menor e com baixo efeito ambiental (Kageyama, 1990), embora forneçam tipos de informações genéticas diferentes. Outras grandes vantagens das isoenzimas são suas propriedades de alelos com expressão codominante, padrão de herança mendeliana e ausência de epistasia e pleiotropia (Wendel \& Weeden, 1989).

A utilização da eletroforese de isoenzimas, para descrever a distribuição da variação genética em populações naturais, apresenta inúmeras 
vantagens: a) a herança genética dos traços detectados eletroforeticamente podem ser facilmente demonstradas; b) a maioria dos locos alozimáticos são codominantes e as freqüências alélicas podem ser calculadas sem a necessidade de cruzamentos genéticos; c) a estimativa da variação genética pode ser comparada diretamente entre populações ou espécies (Hamrick et al., 1979).

Moraes (1993), estudando a variabilidade genética de duas populações de Myracroduon urundeuva F.F. \& M.F. Allemão, por isoenzimas e caracteres quantitativos, apresenta vantagens do primeiro método sobre o segundo.

Alfenas et al (1991) descrevem o método de eletroforese de isoenzimas com detalhes para essências florestais. Moraes (1993), por sua vez, faz um levantamento dos sistemas enzimáticos mais utilizados em coníferas e angiospermas, citando para as últimas a Mdh, Aat, Lap, Per, Pgi, Pgm, Skdh, Acp, G6pd, Idh e Est. Testou, ainda, estes sistemas com duas populações de aroeira, além do Adh, $\alpha$-Est, $\beta$-Est, Ald, G2d, Gdh e Me.

\subsection{Diversidade Genética}

A floresta tropical úmida é sem duvida o ecossistema de maior diversidade de espécies e complexidade de relações ecológicas, sendo um modelo de difícil entendimento para a conservação de seus recursos in situ. Além do mais, nestes ecossistemas faltam muitos estudos de diversidade genética, sendo este o maior desafio existente aos conservacionistas de recursos genéticos (Kageyama, 1987).

Estudos de estrutura genética das espécies de ecossistemas de matas ciliares são fundamentais para o estabelecimento de critérios adequados 
de amostragem das populações, para serem utilizados na recomposição de matas ciliares objetivando a manutenção de sua diversidade, sendo desta forma necessário entender não só a diversidade das espécies desses ecossistemas, como também a variação genética entre e dentro de suas populações (Kageyama et al.,1989).

Segundo os autores acima citados podem, ainda, existir outros fatores de restrições ao fluxo gênico para espécies exclusivas destes ecossistemas, como a área restrita ao longo das margens dos rios, com as populações formando um corredor no sentido montante justante, com conseqüente diminuição do tamanho da vizinhança. Outro aspecto importante do fluxo gênico unidirecional, via sementes no sentido montante justante, é que as populações mais próximas à nascente têm uma entrada muito menor de genes via semente do que as populações mais próximas à foz do rio, o que vai aumentar a diversidade destas ultimas populações.

Do ponto de vista da conservação genética as plantas podem ser divididas em dois grupos, dependendo do fato de serem predominantemente autopolinizadas (autógamas) ou serem, em grande parte, de polinização cruzada (alógamas). A determinação da forma preferencial de acasalamento é importante para a correta determinação dos métodos de melhoramento e conservação a serem aplicados à espécie estudada, já que estas estratégias diferem para diferentes sistemas reprodutivos (Dias \& Kageyama, 1982).

A diversidade genética ou a variação devido a diferenças nos alelos pode ocorrer a diferentes níveis: i) de espécie dentro de ecossistemas, ii) de populações dentro de espécies; e iii) de indivíduos dentro de populações; sendo a caracterização destes níveis de diversidade básicos para o planejamento das estratégias de conservação genética (Kageyama, 1987).

O estudo da variação genética em populações naturais envolve duas questões básicas: a primeira é descrever os níveis de variação genética 
mantida dentro das populações de espécies; a segunda, de particular importância para a conservação genética, é como a variação genética é partida entre e dentro de populações. Em espécies de plantas, as principais características que influenciam a distribuição da diversidade genética incluem o tamanho efetivo da população, a distribuição geográfica da espécie, o modo de reprodução primário, o sistema de cruzamento, o mecanismo de dispersão de sementes, e o tipo de comunidade que a espécie comumente ocorre (Hamrick, 1982).

Moraes (1993), estudando a variabilidade genética de duas populações de Myracrodruon urundeuva F.F. \& M.F. Allemão, por isoenzimas e caracteres quantitativos, obteve como principais conclusões: i) que as técnicas de eletroforese mostraram-se eficientes no estudo de genética de populações de aroeira, na fase de plântula; ii) as populações estudadas apresentaram uma expressiva taxa de endogamia; baixa taxa aparente de fertilização cruzada; e iii) resultados da variação genética entre e dentro das populações, analisadas pelos características quantitativas apresentaram-se próximas ao obtido pelo método de isoenzimas.

Loveless \& Hamrick (1987), estudando a estrutura genética de espécies arbóreas tropicais por isoenzimas, encontraram no geral uma alta diversidade genética total $\left(\mathrm{H}_{\mathrm{t}}=0,352\right)$, baixa diversidade relativa entre as populações $\left(G_{\mathrm{st}}=0,005\right)$, e que o fluxo gênico entre as populações ocorre pelo vento para algumas espécies e por animais para outras. Observaram, ainda, dois padrões de distribuição: o espacial, que é a distribuição dos genótipos em uma população; e o temporal, que leva ao espacial, que é o fluxo gênico, determinado pela forma de dispersão e polinização.

Hill et al. (1978), em estudo da variação genética de espécies leguminosas ribeirinhas ao longo do Rio Solimões, na Amazônia, observaram que os índices de heterozigosidade e de similariedade genética, os padrões 
demográficos e a biologia indicam estreita correlação entre variabilidade genética e a estratégia adaptativa. As populações com alta probabilidade de extinção são mais homozigotas que as com maior probabilidade de sobrevivência, isto é, populações que sofrem perturbações são mais homozigotas. 


\section{MATERIAL E MÉTODOS}

\subsection{Descrição da Área de Estudo}

O trabalho de campo foi realizado na Estação Ecológica do Panga, que compreende uma área de 403,85 hectares localizada no sul do município de Uberlândia, MG (Figura 2).

O clima da região é do tipo Aw, com verão quente e úmido e inverno frio e seco (Schiavini,1992).

Na Estação Ecológica do Panga, são encontrados os principais tipos fisionômicos que caracterizam a região de cerrados do Brasil Central. Encontramse representados tipos florestais como Mata Mesófila (de galeria e de encosta) e Mata Xeromórfica (Cerradão); diversos tipos savânicos , como o Cerrado (sentido restrito), Campo Cerrado e Campo Sujo, além do tipo campestre, representado pelos Campos Úmidos e Veredas (Schiavini \& Araújo, 1989).

Dentre os tipos de vegetação, a área escolhida para o estudo foi a Mata de Galeria, distribuída principalmente ao longo do Córrego do Panga que constitui o limite norte da reserva e, em menor escala, nos canais de drenagem e pequenos córregos existentes na porção sudeste da reserva. A mata de Galeria ocupa os vales de canais de drenagem bem marcados, ou cabeceiras de nascentes, sempre associadas a solos bastante úmidos e, algumas vezes, encharcados (Schiavini \& Araújo, 1989). 


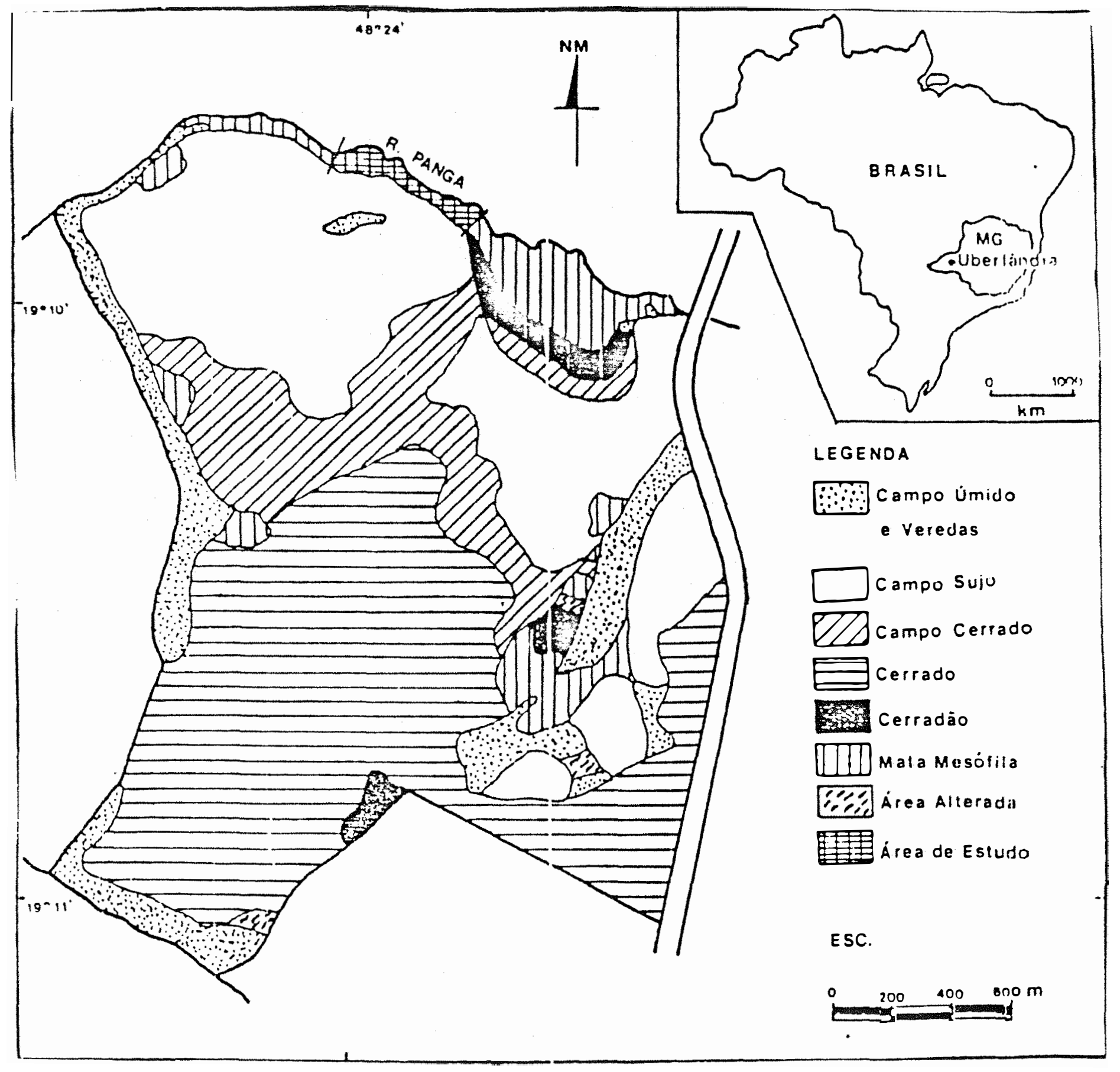

Figura 2. Mapa de localização da Estação Ecológica do Panga, no município de Uberlândia, MG. Destaque para a cobertura Vegetal e localização da área de estudo. (adaptado de Schiavini, 1992). 
A Mata de Galeria possui em torno de 5 hectares em todo seu limite e extensão, e é limitada de um lado pelo Córrego do Panga e de outro por uma faixa de Campo Úmido, ao longo de toda sua borda, apresentando uma mudança brusca da vegetação (Figura 3 ).

C. brasiliense é uma espécie muito comum (230 indivíduos adultos por hectare) na área de estudo. Segundo Schiavini (1992), a espécie foi considerada uma das 10 primeiras com maior IVI (índice de valor de importância), ocorrendo em toda extensão da Mata de Galeria.

\subsection{Determinação dos Grupos a Serem Analisados na População}

Para considerar os indivíduos de C. brasiliense da população estudada como adultos. jovens e plântulas, estabeleceu-se a seguinte metodologia: Adultos:

Indivíduos que apresentam acima de $15 \mathrm{~cm}$ de CAP (circunferência à altura do peito):

Jovens:

Indivíduos que apresentam de 7 a $15 \mathrm{~cm}$ de CAP:

Plântulas:

Indivíduos que apresentam até $7 \mathrm{~cm}$ de diâmetro e maiores que $30 \mathrm{~cm}$ de altura.

Como não houve frutificação dos indivíduos no ano de coleta, não foram encontradas plântulas muito pequenas, por isso considerou-se plântulas aquelas maiores que $30 \mathrm{~cm}$ de altura. 


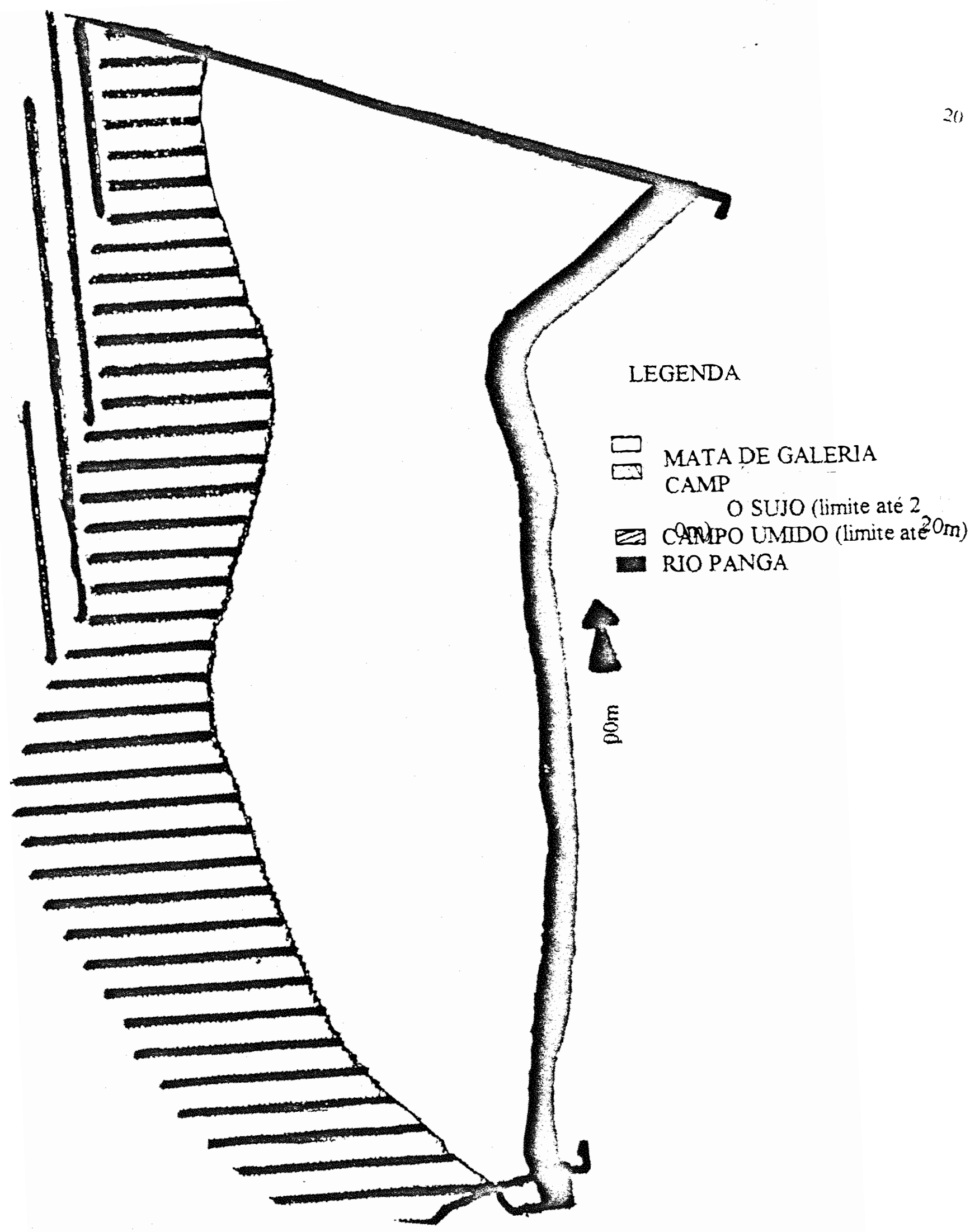

Figura 3. Mapeamento da Mata de Gạha. em detalhe sua delimitaçãe. 
Através dessa metodologia foi possível analisar indivíduos de vários estratos da população estudada. Um estudo de estrutura populacional de $C$. brasiliense, na Estação Ecológica do Panga, demonstrou que são distribuídos na população indivíduos de todos os tamanhos, sendo que em maior quantidade nas classes de menor tamanho (Kawaguici, 1994).

\subsection{Mapeamento da População}

Durante as visitas realizadas na área de estudo, a população foi delimitada. os indivíduos foram marcados e suas folhas coletadas.

A amostragem dos indivíduos na área de estudo foi aleatória, os indivíduos foram marcados numa extensão de $100 \mathrm{~m}$ à margem do Rio Panga e em todo seu limite (de um lado o Rio Panga e de outro uma faixa de campo úmido). Foram marcados 30 indivíduos adultos, 30 jovens e 100 plântulas da espécie. Todos os indivíduos marcados tiveram seus diâmetros e altura medidos.

O intuito de se coletar um maior número de plântulas foi devido ao fato de se encontrar um maior número de indivíduos neste estágio e da grande mortalidade desses indivíduos. A predominância da mortalidade no estágio de plântula é esperada e pode ser justificada por estresses por água, herbivoria (Mantovani, 1989) e seleção natural. Isso deve-se ao fato de que o susceptibilidade das plântulas situa-se logo após o recrutamento, quando deixam de depender das próprias reservas e passam a depender de fatores externos. E, também, pelo fato de que as plântulas são mais susceptíveis a danos catastróficos como queda de árvores, alagamentos, pisoteio, etc, que levaria à morte (Lobo, 1993).

Para cada estágio da planta (adulto, jovem e plântula), utilizou-se uma metodologia para obtenção da altura e do CAP (circunferência a altura do peito) dos indivíduos marcados no campo. 
Nos adultos a altura dos indivíduos foi estimada; o CAP foi medido com auxílio de fita métrica. Nos jovens, a altura dos indivíduos foi medida com trena quando possível ou estimada; o CAP foi medido com fita métrica. A altura das plântulas foi medida utilizando fita métrica e o diâmetro foi medido utilizando paquímetro.

Todos os indivíduos medidos foram marcados com placas de alumínio numeradas e mapeados utilizando papel milimetrado.

\subsection{Coleta de Material}

A coleta das folhas foi realizada na parte da manhã, quando a temperatura se encontra mais amena e a umidade no material vegetal maior. As folhas foram coletadas com auxílio de um podão. Coletou-se as folhas de melhor qualidade possível, ou seja, saudáveis, evitando-se folhas predadas ou parasitadas (fungos), ressecadas e velhas, de preferência sem musgos ou outros que causassem um maior trabalho na sua limpeza. Teve-se preferência às folhas das pontas dos ramos, não expostas diretamente ao sol, em geral as mais saudáveis. Manteve-se os ramos, pois esses impedem de certo modo que a água das folhas se evaporarem rapidamente, até o momento da extração. Envolveu-se as folhas em jornal, evitando oxidação devido ao contato com a água. Essas foram colocadas em sacos plásticos numerados evitando o ressecamento e foram inseridas no isopor com gelo, em saco plástico, isolado por um jornal.

Após a coleta de todos os indivíduos (adultos, jovens e plântulas), transferiu-se todo o material para um refrigerador e, em seguida, foi transferido para a ESALQ/USP, onde foram preparados para eletroforese no Laboratório de Reprodução e Genética de Espécies Arbóreas (LARGEA). 


\subsection{Procedimento de Laboratório}

\subsubsection{Determinação do Protocolo}

O protocolo para os sistemas enzimáticos de C. brasiliense foi baseado em Alfenas et al. (1991), com adaptações para espécies arbóreas tropicais estudadas pelo grupo de pesquisadores do LARGEA, ESALQ/USP. Nas corridas de eletroforese com $C$. brasilense, buscou-se sistemas isoenzimáticos que apresentavam boa resolução para posterior análise dos resultados.

A extração das enzimas foi feita através da maceração de aproximadamente $20 \mathrm{mg}$ de tecido de limbo foliar em placas de porcelana resfriadas utilizando-se cerca de 10mg de areia lavada, Polyvinyl - Pyrrolidone (PVP-360) e Polyvinyl Polypyrrolidone (P-6755) e 200ml de Solução de extração 1 citada por Alfenas et al. (1991) e modificada por Gandara (1996) (Tabela 1).

Os extratos obtidos foram absorvidos em papel de filtro, com $6 \times 10 \mathrm{~mm}$, sendo em seguida colocados no gel. Foram colocados dois pedaços de papel de filtro contendo solução marcadora de azul de bromofenol a $0,1 \%$ nas extremidades do gel.

Para a escolha dos sistemas enzimáticos, foram realizadas análises preliminares de 17 sistemas isoenzimáticos, abaixo relacionados:

. Fosfoglucomutase (Pgm - EC 2.7.5.1)

. 6 - Fosfogluconato Desidrogenase (6Pgdh - EC 1.1.1.44)

. Glucose Desidrogenase (Gludh - EC 1.1.1.47)

. Fosfoglucose Isomerase (Pgi - EC 5.3.1.9)

. Glucose - 6 - Fosfoto Desidrogenase (G6pdh - EC 1.1.1.49)

. Glicerato - Desidrogenage (G2dh - EC 1.1.1.29)

. Glutamato - Oxalacetato Transaminase (Got - EC 2.6.1.1)

. Isocitrato Desidrogenase (Idh - EC 1.1.1.42)

. Leucina Aminopeptidase (Lap - EC 3.4.11.1) 
. Malato Desidrogenase (Mdh - EC 1.1.1.37)

. Manitol Desidrogenase (Madh - EC 1.1.1.67)

. Superóxido Dismutase (Sod - EC 1.15.1.1)

. Xiquimato Desidrogenase (Skdh - EC 1.1.1.25)

. Álcool Desidrogenase (Adh - EC 1.1.1.25)

. Esterase (a-Est - EC 3.1.1.1)

. Fosfatase Ácida (Acp - EC 3.1.3.2)

. Peroxidase (Prx - EC 1.11.1.7)

Tabela 1. Solução de extração utilizada em C. brasiliense Camb. Piracicaba - SP. ESALQ/USP, 1999.

\begin{tabular}{lc}
\hline \multicolumn{1}{c}{ COMPOSTO } & QUANTIDADE \\
\hline Fosfato de Sódio bibásico $(0,034 \mathrm{M})$ & $0,6 \mathrm{~g}$ \\
Sacarose $(0,2 \mathrm{M})$ & $7 \mathrm{~g}$ \\
Polivinil pirrolidona PVP-40 $(2,56 \%)$ & $2,56 \mathrm{~g}$ \\
L-ácido ascórbico & $100 \mathrm{mg}$ \\
Dietilditiocarbamato DIECA $(5,8 \mathrm{mM})$ & $100 \mathrm{mg}$ \\
Bissulfito de Sódio $(2,6 \mathrm{mM})$ & $50 \mathrm{mg}$ \\
Borato de Sódio $(2,6 \mathrm{mM})$ & $50 \mathrm{mg}$ \\
Polietillenoglicol-6000 $(1 \%)$ & $1 \mathrm{~g}$ \\
Água destilada (q.s.p.) & $100 \mathrm{ml}$ \\
\hline
\end{tabular}

Foram também testados 4 sistemas de tampão gel/eletrodo: tris citrato TC (Soltis et al., 1983), citrato morfolina CM (Clayton \& Tretiak, 1972), histidina (H) (Stuber et al., 1988) e tris citrato borato (TCB) (Alfenas et al., 1991). 


\subsection{Análise Estatística dos Dados}

\subsubsection{Análise das Frequências Alélicas dos Grupos}

As frequências alélicas descrevem a variação para um loco e foram obtidas pela contagem direta do número de alelos por loco, dividido pelo número total de alelos no loco, da seguinte forma:

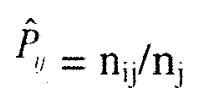

em que:

$\hat{P}_{\|}=$frequência do alelo i na população j;

$\mathrm{n}_{\mathrm{ij}}=$ número de ocorrência do alelo i na população j;

$\mathrm{n}_{\mathrm{j}}=$ número total de alelos amostrados na população $\mathrm{j}$.

Estas estimativas foram obtidas a partir do programa BIOSYS- 2, desenvolvido por Swofford \& Selander (1997).

\subsubsection{Diferenças nas Frequiências Alélicas entre Grupos}

Para verificar se as freqüências alélicas e genotípicas entre os grupos eram diferente, aplicou-se um teste qui-quadrado $\left(\chi^{2}\right)$ de contingência, comparou-se todos os grupos simultaneamente, e separadamente de dois a dois. O teste de $\chi^{2}$ de contingência, para freqüências alélicas de diferentes grupos, foi realizado comparando-se as freqüência observadas contra as esperadas em relação a média dos grupos, conforme Tabela 2 e 3. 
Tabela 2. Freqüências alélicas para cada grupos, para a média dos grupos e tamanho da amostra em um loco com dois alelos. ESALQ/USP. 1999.

\begin{tabular}{ccccc}
\hline Alelos & Plântulas & Jovens & Adultos & Média \\
\hline$N$ & $N_{I}$ & $N_{2}$ & $N_{3}$ & \\
$p$ & $p_{1}$ & $p_{2}$ & $p_{3}$ & $\bar{p}=\frac{p_{1}+p_{2}+p_{3}}{3}$ \\
$q$ & $q_{1}$ & $q_{2}$ & $q_{3}$ & $\bar{q}=\frac{q_{1}+q_{2}+q_{3}}{3}$ \\
\hline
\end{tabular}

Tabela 3. Freqüências alélicas observadas e esperadas em diferentes grupos. ESALQ/USP. 1999.

\begin{tabular}{|c|c|c|c|c|c|c|}
\hline \multirow[b]{2}{*}{ Alelos } & \multicolumn{3}{|c|}{$\begin{array}{c}\text { Freqüências alélicas } \\
\text { observadas }\end{array}$} & \multicolumn{3}{|c|}{ Freqüências alélicas esperadas } \\
\hline & Plântulas & Jovens & Adultos & Plântulas & Jovens & Adultos \\
\hline $\mathrm{p}$ & $p_{1} N_{l}$ & $p_{2} N_{2}$ & $p_{3} N_{3}$ & $\bar{p} N_{1}$ & $\bar{p} N_{2}$ & $\bar{p} N_{3}$ \\
\hline 9 & $q_{1} N_{l}$ & $q_{2} N_{2}$ & $q_{3} N_{3}$ & $\bar{q} N_{1}$ & $\bar{q} N_{2}$ & $\bar{q} N_{3}$ \\
\hline
\end{tabular}

$$
\begin{aligned}
& \chi_{\text {Contingência }}^{2}=\frac{\left(p_{1} N_{1}-\bar{p} N_{1}\right)^{2}}{\bar{p} N_{1}}+\frac{\left(p_{2} N_{2}-\bar{p} N_{2}\right)^{2}}{\bar{p} N_{2}}+\ldots+\frac{\left(q_{3} N_{3}-\bar{q} N_{3}\right)^{2}}{\bar{q} N_{3}} \\
& \mathrm{GL}=(\mathrm{n}-1)(\mathrm{s}-1)
\end{aligned}
$$

onde :

$$
\begin{aligned}
& N_{i}=\text { tamanho da amostra; } \\
& \mathrm{n}=\text { número de alelos; } \\
& \mathrm{S}=\text { número de populações. }
\end{aligned}
$$


O teste de $\chi^{2}$ de contingência para frequiências genotípicas de diferentes grupos foi realizado comparando-se as frequiencias observadas contra as esperadas em relação a média dos grupos, conforme Tabela 4.

Tabela 4. Freqüências genotípicas observadas e esperadas em diferentes grupos. ESALQ/USP. 1999.

\section{Freqüências alélicas}

Frequiências alélicas esperadas observadas

\begin{tabular}{cccccccc} 
Alelos & Plântulas & Jovens & Adultos & Média & Plântulas & Jovens & Adultos \\
\hline$A_{1} A_{1}$ & $P_{1}$ & $P_{2}$ & $P_{3}$ & $\bar{P}$ & $P_{i}$ & $P_{2}$ & $P_{3}$ \\
$A_{1} A_{2}$ & $H_{1}$ & $H_{2}$ & $H_{3}$ & $\bar{H}$ & $H_{i}$ & $H_{2}$ & $H_{3}$ \\
$A_{2} A_{2}$ & $Q_{1}$ & $Q_{2}$ & $Q_{3}$ & $\bar{Q}$ & $Q_{i}$ & $Q_{2}$ & $Q_{3}$ \\
& $N_{1}$ & $N_{2}$ & $N_{3}$ & $\bar{N}$ & & & \\
\hline
\end{tabular}

$$
\begin{aligned}
& P_{i}=(\bar{P} / \bar{N}) \times N_{l} \\
& H_{i}=(\bar{H} / \bar{N}) \times N_{l} \\
& Q_{i}=(\bar{Q} / \bar{N}) \times N_{l}
\end{aligned}
$$

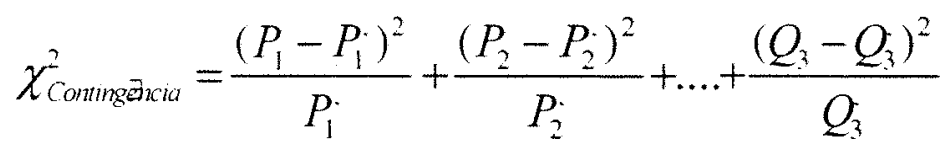

$$
\mathrm{GL}=(\mathrm{n}-1)(\mathrm{s}-1)
$$

onde :

$$
N_{i}=\text { tamanho da amostra; }
$$


$\mathrm{n}=$ número de alelos;

$\mathrm{S}=$ número de populações.

\subsubsection{Divergência Genética entre Grupos de Indivíduos ( $\hat{F}{ }_{\text {sT }}$ )}

$\hat{F}_{\text {ST }}$ corresponde à divergência genética nas frequiências alélicas. O $\hat{F}_{\text {ST }}$ foi estimado entre jovens e adultos, jovens e plântulas e adultos e plântulas. Como a estatística $F$ divide é uma medida de variância entre frequências alélicas de diferentes grupos, ela pode ser utilizada para comparar diferentes grupos estruturados no espaço, bem como no tempo, de acordo com Vencovsky (informações pessoais).

Reis (1996), trabalhando com Euterpe edulis, utilizou o $\hat{F}_{\text {ST }}$ para comparar frequências alélicas de óvulo e polén. Lepsch-Cunha (1996) usou a estatística $\hat{F}$ para comparar além do pólen e óvulo, as frequências alélicas entre 12 famílias, em Couratari guianenses. Gandara (1996), em Cedrela fissilis, comparou pólen com óvulo, óvulo com árvores adultas e pólen com árvores adultas. Sebbenn (1997) utilizou os $\hat{F}_{\text {ST }}$ para comparar as frequências entre sexos, entre pólen e óvulo, pólen e árvores masculinas, óvulos e árvores femininas e heterogeinidade nas frequências alélicas do pólen em Genipa americana.

O $\hat{F}_{\text {ST }}$ foi obtido através do programa BIOSYS-2 de Swofford \& Selander (1997), baseado no modelo de Weir \& Cockehan (1984).

O teste de significância para $\hat{F}_{\mathrm{ST}}$ a nível de locos, foi obtido pelo $\chi^{2}$ de contingência, da mesma forma como é apresentado no ítem 3.6.2.

Para testar a significância da média de $\hat{F}_{\mathrm{ST}}$, utilizou-se um teste de aleatorização sobre os locos ou o "Jackknife". 


\subsection{4 Índice de Diversidade Genética}

Para estimativa de parâmetros que medem a diversidade foi utilizado o programa BJOSYS-2 de Swofford \& Selander (1997), onde foram feitas as estimativas das herozigosidade média observada e esperada por loco $\left(H_{0}, \hat{H}_{e}\right)$, número médio de alelos por loco $(\mathrm{A})$, porcentagem de locos polimórficos $(\mathrm{P})$ e índices de fixação de Wright ( $\hat{f}$ ), da seguinte forma:

a) Heterozigosidade Média Observada $\left(\mathrm{H}_{\mathrm{O}}\right)$

A heterozigosidade média Observada $\left(H_{0}\right)$ para cada loco foi obtida pela expressão:

$$
H_{\mathrm{o}}=1-\sum \mathrm{P}_{\mathrm{ii}}
$$

em que:

$P_{i i}=$ freqüência dos genótipos homozigotos;

Calculou-se individualmente cada loco e para a média dos locos (média aritmética considerando locos monomórficos).

b) Heterozigosidade Média esperada $\left(\hat{\mathrm{H}}_{\mathrm{e}}\right)$

A heterozigosidade média esperada, segundo as espectativas do equilíbrio de Hardy- Weinberg, foi estimada para cada loco, conforme Nei (1977):

$$
\hat{H}_{\mathrm{e}}=1-\Sigma \mathrm{p}_{\mathrm{i}}^{2},
$$


em que:

$\mathrm{P}_{\mathrm{i}}=$ frequência alélica estimada do iésimo alelo.

A heterozigosidade média esperada foi obtida para cada loco e para a média dos locos [média aritmética entre todos os locos analisados (polimóficos e monomórficos)].

c) Número Médio de Alelos por Loco (A)

O número médio de alelos por loco foi obtido somando-se todos os alelos observados e dividindo esse número pelo número total de locos amostrados.

d) Porcentagem de Locos Polimórficos (P)

Para a estimativa da porcentagem de locos polimórficos foram considerados os locos que apresentavam frequência do alelo mais comum igual ou inferior a 95\%. A porcentagem de locos polimórficos foi calculada dividindo-se o número locos polimórficos pelo número total de locos amostrados.

e) Índice de Fixação de Wright $(\hat{f})$

O índice de fixação de Wright, ou coeficiente de endogamia, foi estimado a nível de locos e média entre locos, segundo Vencovsky (1994), com segue: 


$$
\begin{gathered}
\hat{f}=1-H_{0} / \hat{H}_{\mathrm{e}} \text { (nível de loco) } \\
\hat{f}=1-\sum \mathrm{H}_{\mathrm{o}} / \sum \hat{\mathrm{H}}_{\mathrm{e}} \text { (média ponderada entre locos) }
\end{gathered}
$$

Este índice permite acessar os níveis de fixação alélicas por loco, bem como em nível de média de locos, informando sobre o grau de endogamia dentro das populações.

A significancia do $\hat{f}$ foi obtida a partir de um "Bootstrapping" com 10.000 repetições entre locos. num intervalo de confiança a 95\%. Essa estimativa foi obtida pelo programa GDA (Lewis \& Zaykin, 1999).

\subsubsection{Aderência ao Equilíbrio de Hardy - Weinberg}

Através do programa BIOSYS-2 de Swofford \& Selander (1997), testou-se a adequação dos grupos (adultos, jovens e plântulas) ao equilíbrio de Hardy - Weinberg.

O teste utilizado foi o qui-quadrado $\left(\chi^{2}\right)$ não agrupado, porém, quando os valores das frequiências genotípicas esperadas se apresentavam menores do que 1,00, eram agrupados em classes como: homozigotos para os alelos mais comuns, heterozigotos comuns/raros, homozigotos raros e outros heterozigotos, e testados pelo $\chi^{2}$ agrupado e exato de Fischer. Segundo Weir (1990) e Gomes (1990), esse teste é mais adequado e seguro quando os números esperados nas células têm valores pequenos. 


\subsubsection{Análise de Estrutura Genética dos Grupos (Adultos, Jovens e Plântulas)}

Afim de estimar o tamanho efetivo populacional $\left(\mathrm{N}_{\mathrm{e}}\right)$ dos grupos de indivíduos de $C$. brasiliense, realizou-se análise de variância das frequiências alélicas para cada grupo segundo o modelo de Vencovsky (1992) e Weir (1996).

\subsubsection{Análise de Variância de Freqüuencias Alélicas}

As análises de variâncias foram obtidas a partir do programa GDA (Lewis \& Zaykir, 1999).

Esta análise foi inicialmente realizada ao nível de alelo e, posteriormente, conjunta para todos os alelos. Para cada alelo de cada loco polimórfico das plantas adultas, jovens e das plântulas foi feita a análise de variância no modelo aleatório hierárquico desbalanceado, baseado em Weir (1990). Assim, de acordo com estes autores, a variável $\mathrm{x}_{\mathrm{il}}$ corresponde ao gene "l" na população "i", portanto, quando $x_{i 1}$ estava presente recebeu o valor um, e quando estava ausente recebeu o valor zero.

a) Análise individual para cada Grupo: Adultos, Jovens e Plântulas

A análise de frequiências gênicas de indivíduos adultos, jovens e plântulas de C. brasiliense como uma população baseou-se no modelo:

$$
\mathrm{Y}_{\mathrm{ik}}=\mathrm{m}=\mathrm{b}_{\mathrm{i}}+\mathrm{g}_{\mathrm{k}(\mathrm{i})}
$$


onde :

$Y_{i k}$ : freqüência do gene $i$, dentro do indivíduos $\mathrm{K}$;

m: média geral da freqüência alélica;

$\mathrm{b}_{\mathrm{i}}=$ efeito de indivíduos, com $\mathrm{i}=1,2, \ldots, \mathrm{a}$;

$\mathrm{g}_{\mathrm{k}(\mathrm{i})}$ : efeito do gene $\mathrm{k}$, dentro do indivíduo $\mathrm{i}$, com $\mathrm{k}=1,2, \ldots, \mathrm{b}_{\mathrm{i}}$;

As estimativas dos componentes de variância para os 3 grupos foram obtidas pela decomposição das esperanças dos quadrados médios da análise de variância, conforme Tabela 5, desse modo:

$$
\begin{aligned}
& \hat{\sigma}_{l^{\prime}}^{2}=Q M_{c_{i}} \\
& \hat{\sigma}_{I}^{2}=\left(Q M_{1}-Q M_{c_{i}}\right) / 2
\end{aligned}
$$

Tabela 5: Esquema da análise de variância de frequiência alélicas no modelo hieráquico desbalanciado para adultos, jovens e plântulas de $C$. brasiliense, em uma população, considerando a espécie como dióca. Piracicaba, ESALQ/USP, 1999.

\begin{tabular}{lcclc}
\hline \multicolumn{1}{c}{ FV } & $\mathrm{GL}$ & $\mathrm{SQ}$ & $\mathrm{QM}$ & $\mathrm{E}(\mathrm{QM})^{1}$ \\
\hline Indivíduos & $\sum_{i-1}^{a} b_{l},-\mathrm{a}$ & $\mathrm{SQ}_{1}$ & $\mathrm{QM}_{1}$ & $\hat{\sigma}_{i}^{2}+2 \hat{\sigma}_{l}^{2}$ \\
Genes/Indivíduos & $\mathrm{n} . .-\sum_{i-1}^{a} b_{l}$ & $\mathrm{SQ}_{\mathrm{G}}$ & $\mathrm{QM}_{\mathrm{G}}$ & $\hat{\sigma}_{c_{i}^{2}}^{2}$ \\
\hline Total & $\mathrm{n}-1$ & & & \\
\hline
\end{tabular}


O significado genético dos componentes da variância são definidos

abaixo:

$$
\begin{aligned}
& \hat{\sigma}_{i}^{2}=p(1-p)(\hat{f}) \\
& \hat{\sigma}_{c}^{2}=p(1-p)(1-\hat{f}) \\
& \hat{\sigma}_{T}^{2}=\hat{\sigma}_{i}^{2} /\left(\hat{\sigma}_{T}^{2}\right)=p(1-p)
\end{aligned}
$$

onde: $p=$ freqüência de um gene em um determinado loco:

$\hat{f}=$ correlação entre alelos dentro de indivíduos;

$\hat{\sigma}_{l}^{2}=$ variância entre indivíduos dentro da população;

$\hat{\sigma}_{1}^{2}=$ variância entre genes dentro de indivíduos;

$\hat{\sigma}_{i}^{2}=$ variância genética total.

A estimativa do $\hat{f}$ pode ser obtida dos componentes da variância, da seguinte forma:

$$
\hat{f}=\hat{\sigma}_{i}^{2} /\left(\hat{\sigma}_{T}^{2}\right)=\hat{\sigma}_{I}^{2} /\left(\hat{\sigma}_{I}^{2}+\hat{\sigma}_{(i}^{2}\right)
$$

As estimativas médias dos valores de $\hat{f}$ foram obtidas pela soma dos quadrados médios individuais, dividida pela soma dos graus de liberdade:

$$
\begin{aligned}
& \mathrm{QM}_{\mathrm{l}}=\Sigma \mathrm{SM}_{\mathrm{l}} / \Sigma \mathrm{GL}_{\mathrm{l}} \\
& \mathrm{QM}_{\mathrm{G}}=\Sigma \mathrm{SM}_{\mathrm{G}} / \Sigma \mathrm{GL}_{\mathrm{G}}
\end{aligned}
$$


b) Análise entre e dentro de Grupos

A análise de variância freqüências gênicas de indivíduos adultos, jovens e plântulas de C. brasiliense como uma população baseou-se no modelo matemático:

$$
\mathrm{Y}_{\mathrm{ijk}}=\mathrm{m}+\mathrm{f}_{\mathrm{i}}+\mathrm{b}_{\mathrm{j}(\mathrm{i})}+\mathrm{g}_{\mathrm{k}(\mathrm{ij})}
$$

onde :

$\mathrm{Y}_{\mathrm{ijk}}$ : freqüência do gene $\mathrm{k}$, dentro do indivíduos $\mathrm{j}$, dentro do grupo $\mathrm{i}$;

$\mathrm{m}$ : média geral da frequiência alélica:

$\mathrm{f}_{\mathrm{i}}=$ efeito do grupo, $\operatorname{com} \mathrm{i}=1.2, \ldots, \mathrm{a}$;

$b_{j(i)}$ : efeito do indivíduo $j$, dentro do grupo $i, \operatorname{com} j=1,2, \ldots, b_{i}$;

$\mathrm{g}_{\mathrm{k}(\mathrm{ij})}=$ efeito do gene $\mathrm{k}$, dentro do indivíduo $\mathrm{j}$, dentro do grupo $\mathrm{i}$, com $\mathrm{k}=1,2, \ldots, \mathrm{n}_{\mathrm{ij}}$;

As estimativas dos componentes de variância para os 3 grupos foram obtidas pela decomposição das esperanças dos quadrados médios da análise de variância, conforme Tabela 3, desse modo:

$$
\begin{aligned}
& \hat{\sigma}_{G}^{2}=Q M_{g} \\
& \hat{\sigma}_{I}^{2}=\left(Q M_{l}-Q M_{g}\right) / 2 \\
& \hat{\sigma}_{g}^{2}=\left(Q M_{G}-Q M i\right) k_{I}
\end{aligned}
$$

onde: $\hat{\sigma}_{G}^{2}=$ variância entre genes, dentro de indivíduos, dentro de grupos;

$\hat{\sigma}_{i}^{2}=$ variância entre indivíduos, dentro de grupos;

$\hat{\sigma}_{g}^{2}=$ variância entre grupos de indivíduos. 
$\mathrm{K}_{1}=$ corresponde, ao coeficiente das variâncias entre grupos $\left(\hat{\sigma}_{c_{i}}^{2}\right)$ no modelo hierárquico desbalanciado.

Tabela 6: Esquema da análise de variância de freqüência alélicas no modelo hieráquico desbalanciado para adultos, jovens e plântulas de $C$. brasiliense, em uma população, considerando a espécie como hermafrodita. Piracicaba, ESALQ/USP, 1999.

\begin{tabular}{|c|c|c|c|c|}
\hline FV & GL & SQ & QM & $E(Q M)^{1}$ \\
\hline Grupos & $\sum_{i=1}^{a} b_{i},-\mathrm{a}$ & $\mathrm{SQ}_{\mathrm{G}}$ & $\mathrm{QM}_{\mathrm{G}}$ & $\hat{\sigma}_{\dot{s}}^{2}+2 \hat{\sigma}_{I}^{2}+k_{l} \hat{\sigma}_{i}^{2}$ \\
\hline Indivíduos/Grupos & $\sum_{i=1}^{\prime \prime} \sum_{j-1} c_{1 j}-\sum_{j-1}^{c 1} b_{j}$ & $\mathrm{SQ}_{1}$ & $\mathrm{QM}_{\mathrm{I}}$ & $\hat{\sigma}_{z}^{2}+2 \hat{\sigma}_{i}^{2}$ \\
\hline Genes/Indivíd./Grupos & $n \ldots-\sum_{l=1}^{a} \sum_{l=1}^{b} c_{1 \prime}$ & $\mathrm{SQ}_{\underline{g}}$ & $\mathrm{QM}_{\mathrm{g}}$ & $\hat{\sigma}_{z}^{2}$ \\
\hline Total & $n \ldots-1$ & & & \\
\hline
\end{tabular}

O significado genético dos componentes da variância são definidos abaixo:

$$
\begin{aligned}
& \hat{\sigma}_{G}^{2}=p(1-p)\left(\hat{\theta}_{G}\right) \\
& \hat{\sigma}_{i}^{2}=p(1-p)\left(\hat{f}-\hat{\theta}_{G}\right) \\
& \hat{\sigma}_{g}^{2}=p(1-p)(1-\hat{f}) \\
& \hat{\sigma}_{T}^{2}=\hat{\sigma}_{G}^{2}+\hat{\sigma}_{I}^{2}+\hat{\sigma}_{g}^{2}=p(1-p)
\end{aligned}
$$


onde:

$\mathrm{p}=$ freqüência de um gene em um determinado loco;

$\hat{\theta}_{i i}=$ coeficiente de parentesco ou coancestralidade das plantas dentro dos grupos, ou correlação das freqüências alélicas de diferentes plantas dentro dos grupos;

$\hat{f}=$ correlação entre alelos dentro de indivíduos, ou a probabilidade de 2 alelos amostrados aleatoriamente de um indivíduo serem idênticos por descendência.

A estimativa dos coeficientes de coancestralidade podem ser obtidas dos componentes variância por:

$$
\begin{gathered}
\hat{\theta}_{G}=\hat{\sigma}_{G i}^{2} / \hat{\sigma}_{T}^{2} \\
\hat{f}=1-\left(\hat{\sigma}_{\bar{l}}^{2} / \hat{\sigma}_{T}^{2}\right)=\left(\hat{\sigma}_{l}^{2}+\hat{\sigma}_{l}^{2}\right) / \hat{\sigma}_{l}^{2}
\end{gathered}
$$

As estimativas médias entre locos para os parâmetros $\hat{\theta}_{c_{i}}$ e $\hat{f}$, foram obtidas pela média ponderada dos quadrados médios, da seguinte forma:

$$
\begin{aligned}
& \mathrm{QM}_{\mathrm{G}}=\Sigma \mathrm{SQ}_{\mathrm{G}} / \Sigma \mathrm{GL}_{\mathrm{G}} \\
& \mathrm{QM}_{\mathrm{l}}=\Sigma \mathrm{SQ} / \Sigma \mathrm{GL}_{\mathrm{l}} \\
& \mathrm{QM}_{\mathrm{g}}=\Sigma \mathrm{SQ}_{\mathrm{g}} / \Sigma \mathrm{GL}_{\mathrm{g}}
\end{aligned}
$$




\subsubsection{Tamanho Efetivo}

Para calcular o tamanho efetivo dos grupos de indivíduos de $C$. brasiliense considerou- se a população como sendo dióica e monóica (Marques, 1994).

Considerando $C$. brasiliense como dióica o tamanho efetivo populacional para os 03 grupos de indivíduos foi estimado pelas expressões apresentadas abaixo (Crow \& Kimura, 1970). Para esta estimativa, pressupôs que não existiam diferenças nas frequêencias alélicas entre sexos:

Variância média total populacional para plantas femininas:

$$
\hat{\bar{\sigma}}_{l}^{2}=\frac{\bar{p}(1-\bar{p})}{2 \hat{N}_{c l}}=\frac{\hat{\sigma}_{i}^{2}}{N_{1}}+\frac{\hat{\sigma}_{z}^{2}}{2 N_{1}}
$$

Variância média total populacional para plantas femininas:

$$
\hat{\bar{\sigma}}_{M}^{2}=\frac{\bar{p}(1-\bar{p})}{2 \hat{N}_{c M}}=\frac{\hat{\sigma}_{I}^{2}}{N_{m}}+\frac{\hat{\sigma}_{z}^{2}}{2 N_{m}}
$$

assim:

$$
\hat{\bar{\sigma}}_{F M}^{2}=\hat{\bar{\sigma}}_{F}^{2}+\hat{\bar{\sigma}}_{M}^{2}=\frac{\bar{p}(1-p)}{2 N_{\xi}}
$$

onde:

$\bar{p}(1-\bar{p})=\hat{\sigma}_{T}^{2}$

$\bar{p}=$ freqüência alélica média; 
$\hat{\bar{\sigma}}_{1}^{2}=$ variância total;

$\mathrm{N}_{\mathrm{f}}=$ número de plantas femininas

$\mathrm{N}_{\mathrm{m}}=$ número de plantas masculinas

Considerando $C$. brasiliense como hermafrodita, o tamanho efetivo foi estimado pela expressão apresentada por Vencovsky (1992) para plantas monóicas (flores díclinas e hermafroditas), visto que não foi possível separar os sexos.

$$
\hat{\bar{\sigma}}_{i}^{2}=\frac{\bar{p}(1-\bar{p})}{2 \hat{N}_{c}}=\frac{\hat{\sigma}_{c}^{2}}{m}+\frac{\hat{\sigma}_{i}^{2}}{n m}+\frac{\hat{\sigma}_{c}^{2}}{2 n m}
$$

onde:

$\mathrm{n}=$ número de indivíduos

$\mathrm{m}=$ número de grupos

Expressões que podem servir como orientação para estratégias de amostragem de germoplasmas, ou mesmo visando coleta de sementes para fins de reflorestamentos, em função da grandeza observada dos componentes da variância. A escolha dos números adequados de $\mathrm{m}$ e $\mathrm{n}$ deve minimizar a variância média $\left(\hat{\sigma}_{T}^{2}\right)$. 


\section{RESULTADOS E DISCUSSÃO}

\subsection{Obtenção dos Dados Genéticos}

\subsubsection{Procedimentos de Eletroforese de lsoenzimas}

A partir dos testes preliminares, para definição de um protocolo adequado para estudos isoenzimáticos de C. brasiliense, foram escolhidos 08 sistemas isoenzimáticos (Tabela 7).

Nos testes com tampões gel/eletrodo diferentes demonstraram a maior eficiência em relação à separação e definição de bandas e de locos, de forma a interpretá-los. Além disso foi possível a averiguação da diminuição do tempo de corrida. Em relação às espécies estudadas no LARGEA, esse tempo era de 8 a 10 horas (TC e CM) e de 4 horas com tampões TCB e H.

Dados das corridas eletroforéticas:

. V (Voltagem) inicial no gel: $10 \mathrm{~V}$

. V inicial na fonte: 120 a $170 \mathrm{~V}$

. V final no gel: 18 a $32 \mathrm{~V}$

. V final máxima na fonte: 200 a350V

. I (corrente) inicial: 25 a $40 \mathrm{~mA}$

. I final: 25 a $40 \mathrm{~mA}$

. Tempo de corrida: 4 horas 
Tabela 7. Enzimas, sistema de tampão gel/eletrodo e número de locos observados na determinação do protocolo. Piracicaba, ESALQ/USP, 1999.

\begin{tabular}{ccc}
\hline Enzima & $\begin{array}{c}\text { Sistema Tampão } \\
\text { Gel/ Eletrodo }\end{array}$ & $\begin{array}{c}\mathrm{N}^{0} \text { de locos } \\
\text { Observados }\end{array}$ \\
\hline 6PGDH & $\mathrm{H}$ & 1 \\
MDH & & 2 \\
PO & & 1 \\
SKDH & TCB & 1 \\
PGI & & 3 \\
GOT & & 2 \\
LAP & 3 \\
ACP & & 3 \\
\hline
\end{tabular}

O protocolo utilizado para $C$. brasiliense foi adaptado de Alfenas et al., 1991 (Anexos). Os sistemas isoenzimáticos que obtiveram boa resolução e possibilidade de interpretação genética em C. brasiliense, também foram usados e tiveram resultados positivos em outras espécies vegetais, como por exemplo:

.6Pgdh: (Bawa \& O’Malley, 1987; Gandara, 1996; Lepsch-Cunha, 1996)

.Mdh: (Reis, 1996; Lepsch-Cunha, 1996; Marcon, 1988; Gandara, 1996; Schnabel \& Hamrick, 1990; Liengsiri et al., 1995; Pérez-Nasser, 1993).

.Prx: (Gandara, 1996; Lepsch-Cunha, 1996).

.Skdh: (Schnabel \& Hamrick, 1990; Lepsch-Cunha, 1996).

.Pgi: (Schnabel \& Hamrick, 1990; Hill et al., 1978; Pérez-Nasser, 1993; Liengsiri et al., 1995; Gandara, 1996; Lepsch-Cunha, 1996; Reis, 1996).

.Got: (Marcon, 1988; Bawa \& O’Malley, 1987; Schnabel \& Hamrick, 1990). 
.Lap: (Hill et al., 1978; Schnabel \& Hamrick, 1990; Pérez-Nasser, 1993; Gandara, 1996; Marcon, 1988; Morais, 1993; Reis, 1996).

.Acp: (Schnabel \& Hamrick, 1990).

\subsubsection{Interpretação Genética dos Zimogramas}

A interpretação genéticas dos zimogramas obtidos, para os oito sistemas enzimáticos utilizados no presente trabalho, é apresentada esquematicamente na Figura 4. Essas são condizentes com os padrões encontrados no estudo de outras espécies, principalmente no que se refere à estrutura das enzimas, número de locos por sistema enzimático e número de alelos por locos.

\section{Malato Desidrogenase (Mdh)}

Este sistema revelou uma zona de atividade formada por um loco polimórfico e multialélico ( 3 alelos), constituída por uma enzima monomérica.

\section{6- Fosfogluconato desidrogenase (6-Pgdh)}

Este sistema apresentou apenas uma zona de atividade, interpretada como um loco polimórfico, com três alelos e enzima monomérica.

\section{Shiquimato Desidrogenase (Skdh)}

Esta enzima revelou uma zona de atividade, interpretada como um loco de estrutura monomérica, polimórfica com dois alelos. 

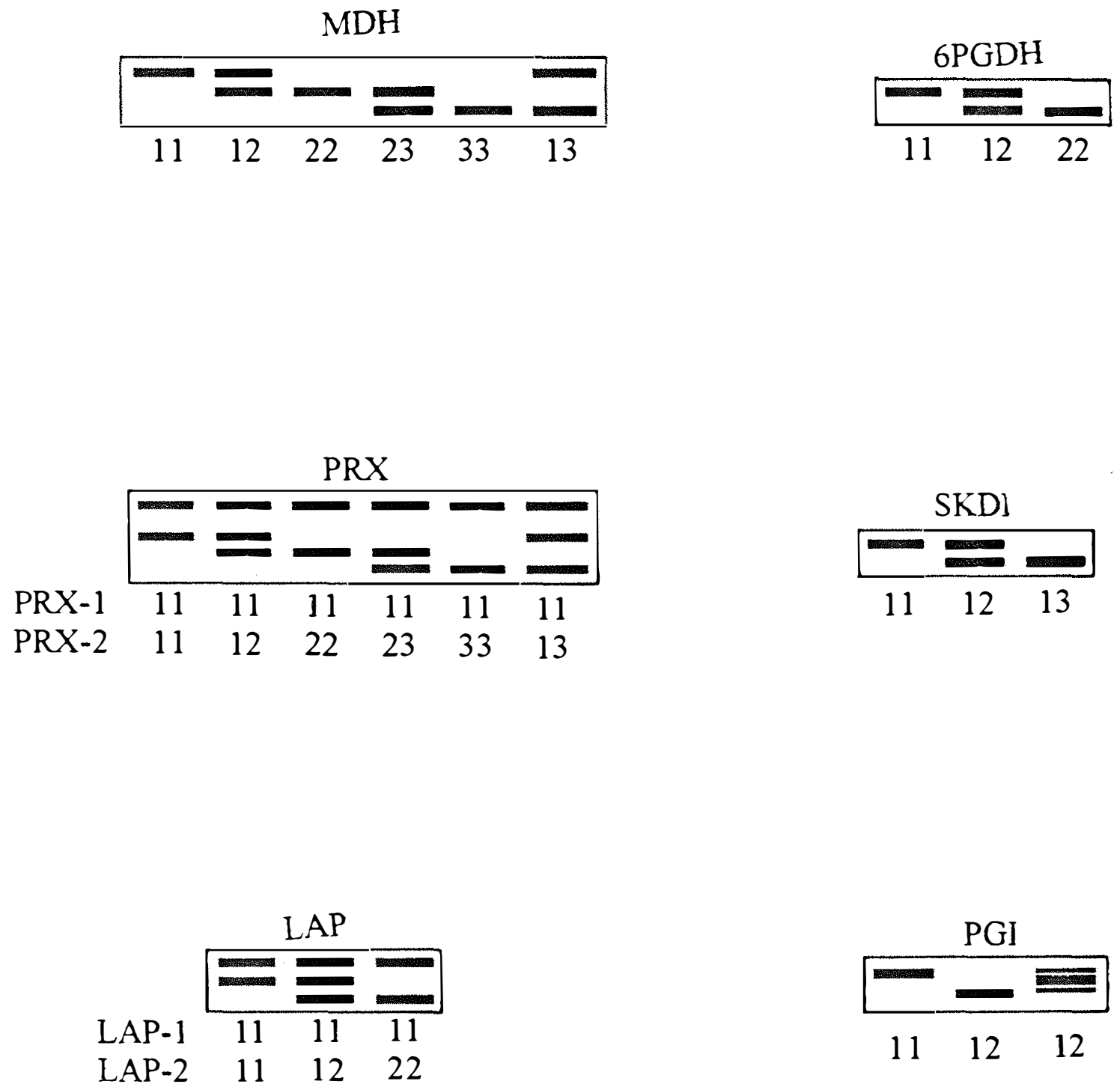

Figura 4. Interpretação Genética dos Zimogramas dos Sistemas Enzimáticos Polimórficos Utilizados no Estudo de Plântulas, Jovens e Adultos de uma População de C. brasiliense Camb. na Estação Ecológica do Panga (Uberlândia - MG). Piracicaba - SP, ESALQ/USP, 1999. 


\title{
Peroxidase (Prx)
}

\begin{abstract}
A peroxidase exibiu duas regiões positivas, sendo uma constituída por um loco polimófico de estrutura monomérica, formada de três alelos e outra constituída por 1 loco monomórfico.
\end{abstract}

\section{Fosfoglucose Isomerase (Pgi)}

Esta enzima apresentou um loco polimófico, dimérico e dialélico.

\section{Glutamato- Oxalacetato Transminase (Got)}

Este sistema apresentou três zonas de atividade, formadas por três locos monomórficos, com um alelo fixado.

\section{Fosfatase Ácida (Acp)}

Este sistema também apresentou três zonas de atividade, formadas por três locos monomórficos.

\section{Leucina Aminopeptidase (Lap)}

A Leucina aminopeptidase apresentou somente duas zonas de atividade, interpretada como locos polimórficos, com dois alelos cada e estrutura monomérica. 


\subsection{Análise das Frequiências Alélicas dos Grupos}

A estimativa da variabilidade genética foi obtida a partir de 22 alelos distribuídos em 14 locos isoenzimáticos (Tabela 8), encontrados nos três grupos de C. brasiliense.

As freqüências alélicas oscilaram nos locos polimórficos entre os diferentes grupos, de completa fixação, como no caso do alelo 1 dos locos Prx-1, Got-1, Got-2, Got-3, Acp-1, Acp-2, Acp-3 e Lap-1, igualmente nos adultos, jovens e plântulas, até frequências muito baixas, como no caso alelo 2 do loco Prx-1 (0.033 dos adultos), considerados alelos raros.

As maiores freqüências alélicas foram, respectivamente, para plântulas. jovens e adultos, do alelo r do loco Mdh-1, alelo p dos locos 6Pgdh-1, Pgi-1 e Lap-2. No loco Prx-2 os alelos mais freqüentes foram p nas plântulas e jovens e alelo $\mathrm{r}$ nos adultos, no loco Skdh-l o alelo mais freqüente foi o $\mathrm{p}$ das plântulas e alelo q dos jovens e adultos.

A fim de verificar se haverá divergência entre as freqüências alélicas entre os grupos, utilizou-se a medida de divergência genética entre frequiências alélicas $F_{S T}$ de Wright (1965) (Tabela 9). A significância do $F_{S T}$ foi dada por um teste de $\mathrm{X}^{2}$ de contingência entre as combinações dos grupos (plântulas/jovens, plântulas/adultos, jovens/adultos).

O teste de contingência para verificar se as frequiências alélicas (Tabela 8) e as freqüências genotípicas (Tabela 10) eram diferentes entre os grupos foi significativo para 5 dos 6 locos polimórficos avaliados, sugerindo que essas diferenças não podem ser atribuídas ao acaso. 
Tabela 8. Freqüências alélicas para 6 locos isoezimáticos polimórficos detectados e teste de $\mathrm{X}^{2}$ de contingência em $C$. brasiliense. (ns: não significativo; $* 5 \% ; * *: 1 \%)$. Piracicaba. ESALQ/USP. 1999.

\begin{tabular}{|c|c|c|c|c|c|c|}
\hline & Alelos & Plântulas & Jovens & Adultos & $\mathrm{X}^{2}$ & GL \\
\hline \multirow[t]{4}{*}{ Mdh-1 } & $P$ & 0,200 & 0,250 & 0,217 & & \\
\hline & Q & 0,315 & 0,300 & 0,233 & & \\
\hline & $\mathrm{R}$ & 0,485 & 0,450 & 0,550 & & \\
\hline & $\mathrm{N}$ & 100 & 30 & 30 & 1,32 ns & 4 \\
\hline \multirow[t]{2}{*}{ Prx-1 } & $P$ & 1.000 & 1,000 & 1,000 & & \\
\hline & $\mathrm{N}$ & 100 & 30 & 30 & 0,00 & \\
\hline \multirow[t]{4}{*}{$\operatorname{Prx}-2$} & $P$ & 0,490 & 0,733 & 0,450 & & \\
\hline & Q & 0.170 & 0,083 & 0,033 & & \\
\hline & $\mathrm{R}$ & 0.340 & 0.183 & 0.517 & & \\
\hline & $\mathrm{N}$ & 100 & 30 & 30 & $15.02 * *$ & 4 \\
\hline \multirow[t]{3}{*}{ 6Pgdh-1 } & $P$ & 0.582 & 0.817 & 0,563 & & \\
\hline & Q & 0,418 & 0,183 & 0,438 & & \\
\hline & $\mathrm{N}$ & 100 & 30 & 30 & $6,91 *$ & 2 \\
\hline \multirow{3}{*}{ Skdh-1 } & $P$ & 0,583 & 0,450 & 0,350 & & \\
\hline & Q & 0,462 & 0,550 & 0,650 & & \\
\hline & $\mathrm{N}$ & 100 & 30 & 30 & $4.55 *$ & 2 \\
\hline \multirow[t]{3}{*}{ Pgi-1 } & $P$ & 0,760 & 0,600 & 0.500 & & \\
\hline & Q & 0,240 & 0,400 & 0.500 & & \\
\hline & $\mathrm{N}$ & 100 & 30 & 30 & $10,20 * *$ & 2 \\
\hline \multirow[t]{2}{*}{ Got-1 } & $\mathrm{P}$ & 1.000 & 1,000 & 1,000 & & \\
\hline & $\mathrm{N}$ & 100 & 30 & 30 & 0,00 & \\
\hline \multirow[t]{2}{*}{ Got-2 } & $\mathrm{P}$ & 1,000 & 1,000 & 1,000 & & \\
\hline & $\mathrm{N}$ & 100 & 30 & 30 & 0,00 & \\
\hline \multirow[t]{2}{*}{ Got-3 } & $P$ & 1,000 & 1,000 & 1,000 & & \\
\hline & $\mathrm{N}$ & 100 & 30 & 30 & 0,00 & \\
\hline \multirow[t]{2}{*}{ Acp-1 } & $P$ & 1,000 & 1,000 & 1,000 & & \\
\hline & $\mathrm{N}$ & 100 & 30 & 30 & 0,00 & \\
\hline \multirow[t]{2}{*}{ Acp-2 } & $P$ & 1.000 & 1,000 & 1,000 & & \\
\hline & $\mathrm{N}$ & 100 & 30 & 30 & 0,00 & \\
\hline \multirow[t]{2}{*}{ Acp-3 } & $P$ & 1,000 & 1,000 & 1,000 & & \\
\hline & $\mathrm{N}$ & 100 & 30 & 30 & 0.00 & \\
\hline \multirow[t]{2}{*}{ Lap-1 } & $P$ & 1,000 & 1,000 & 1,000 & & \\
\hline & $\mathrm{N}$ & 100 & 30 & 30 & 0,00 & \\
\hline \multirow[t]{3}{*}{ Lap-2 } & $\mathrm{P}$ & 0,805 & 0,867 & 0.533 & & \\
\hline & q & 0,195 & 0,133 & 0,467 & & \\
\hline & $\mathrm{N}$ & 100 & 30 & 30 & $11,48 * *$ & 2 \\
\hline $\begin{array}{c}\text { Total de } \\
\text { Alelos }\end{array}$ & & 22 & 22 & 22 & & \\
\hline
\end{tabular}


Tabela 9. Estimativa de divergência genética $\left(\hat{F}_{\mathrm{ST}}\right)$ entre Adultos e Jovens, Jovens e Plântulas e Adultos e Plântulas, de C. brasiliense, a partir de 8 locos enzimáticos polimórficos. Piracicaba - SP, ESALQ/USP, 1999.

\begin{tabular}{cccc}
\hline Loco & $\begin{array}{c}\hat{F} \text { st } \\
\text { Plântulas/Jovens }\end{array}$ & $\begin{array}{c}\hat{F} \text { sT } \\
\text { Jovens/Adultos }\end{array}$ & $\begin{array}{c}\hat{F} \text { st } \\
\text { Plântulas/Adultos }\end{array}$ \\
\hline Mdh-1 & $-0,0076 \mathrm{~ns}$ & $-.0,0052 \mathrm{~ns}$ & $-0,0020 \mathrm{~ns}$ \\
Prx-2 & $0,0628^{*}$ & $0,1517^{*}$ & $0,0290^{*}$ \\
6Pgdh-1 & $0,1034^{*}$ & $0,1280^{*}$ & $-0,0095 \mathrm{~ns}$ \\
Skdh-1 & $0,0017 \mathrm{~ns}$ & $-0,0049 \mathrm{~ns}$ & $0,0544^{*}$ \\
Pgi-1 & $0,0466 \mathrm{~ns}$ & $-0,0092 \mathrm{~ns}$ & $0,1327^{* *}$ \\
Lap-2 & $-0,0008 \mathrm{~ns}$ & $0,2145 *$ & $0,1604^{*}$ \\
\hline Média & $0,0356(0,020)^{*}$ & $0,0759(0,042)^{*}$ & $0,0543(0,028)^{*}$ \\
\hline
\end{tabular}

ns: não significativo; *: $5 \% ; * *: 1 \%$ de probabilidade

A divergência genética entre os grupos (Tabela 9) de plântulas/jovens foi significativo, em dois dos seis locos avaliados, e para a média dos locos $(0,0346)$. A divergência entre jovens/adultos foi significativa em três dos seis locos, bem como para a média. $\mathrm{O} \hat{F}$ sт entre o grupo de plântulas/adultos foi significativo em quatro dos seis locos, bem como para a média dos locos $(0,0543)$. A divergência entre as freqüências alélicas dos grupos foi alta, indicando a presença de deriva genética, e/ou seleção, como coloca Reis (1996). Como discutido anteriormente, possivelmente a causa da divergência entre os grupos seja a deriva genética, dado que a hipótese de seleção só seria sustentada se o grupo de jovens fosse descartado da análise. 
Tabela 10. Frequências genotípicas para 6 locos isoezimáticos polimórficos detectados e teste $\mathrm{X}^{2}$ de contingência em C. brasiliense. (ns: não significativo;*:5\%; **: 1\%). Piracicaba, ESALQ/USP. 1999.

\begin{tabular}{|c|c|c|c|c|c|c|}
\hline Loco & Classes & Plântulas & Jovens & Adultos & $X^{2}$ & GL \\
\hline \multirow[t]{6}{*}{ Mdh-1 } & $\mathrm{A}_{1} \mathrm{~A}_{1}$ & 0,080 & 0,100 & 0,100 & & \\
\hline & $A_{1} A_{2}$ & 0,130 & 0,233 & 0,100 & & \\
\hline & $A_{1} A_{3}$ & 0,110 & 0,067 & 0,133 & & \\
\hline & $\mathrm{A}_{2} \mathrm{~A}_{2}$ & 0,050 & 0,000 & 0,033 & & \\
\hline & $\mathrm{A}_{2} \mathrm{~A}_{3}$ & 0,400 & 0,367 & 0,300 & & \\
\hline & $\mathrm{A}_{3} \mathrm{~A}_{3}$ & 0,230 & 0,233 & 0,333 & $6,24 \mathrm{~ns}$ & 10 \\
\hline \multirow[t]{6}{*}{ Prx-2 } & $\mathrm{A}_{1} \mathrm{~A}_{1}$ & 0,270 & 0,533 & 0,300 & & \\
\hline & $A_{1} A_{2}$ & 0,150 & 0,167 & 0,033 & & \\
\hline & $A_{1} A_{3}$ & 0,290 & 0,233 & 0,267 & & \\
\hline & $\mathrm{A}_{2} \mathrm{~A}_{2}$ & 0,050 & 0,00 & 0,00 & & \\
\hline & $\mathrm{A}_{2} \mathrm{~A}_{3}$ & 0,090 & 0,00 & 0,033 & & \\
\hline & $\mathrm{A}_{3} \mathrm{~A}_{3}$ & 0,150 & 0,067 & 0,367 & $23,189 *$ & 10 \\
\hline \multirow[t]{3}{*}{ 6Pgdh-1 } & $A_{1} A_{1}$ & 0,267 & 0,667 & 0,292 & & \\
\hline & $\mathrm{A}_{1} \mathrm{~A}_{2}$ & 0,612 & 0,300 & 0,542 & & \\
\hline & $\mathrm{A}_{2} \mathrm{~A}_{2}$ & 0,112 & 0,033 & 0,167 & $16,74 * *$ & 4 \\
\hline \multirow[t]{3}{*}{ Skdh-1 } & $A_{1} A_{1}$ & 0,337 & 0,300 & 0,267 & & \\
\hline & $A_{1} A_{2}$ & 0,402 & 0,300 & 0,167 & & \\
\hline & $\mathrm{A}_{2} \mathrm{~A}_{2}$ & 0,261 & 0,400 & 0,567 & $10,61 * *$ & 4 \\
\hline \multirow[t]{3}{*}{ Pgi-1 } & $A_{1} A_{1}$ & 0,640 & 0,533 & 0,433 & & \\
\hline & $A_{1} A_{2}$ & 0,240 & 0,133 & 0,133 & & \\
\hline & $\mathrm{A}_{2} \mathrm{~A}_{2}$ & 0,120 & 0,333 & 0,433 & $16,54 * *$ & 4 \\
\hline \multirow[t]{3}{*}{ Lap-2 } & $\mathrm{A}_{1} \mathrm{~A}_{1}$ & 0,667 & 0,800 & 0,400 & & \\
\hline & $A_{1} A_{2}$ & 0,265 & 0,133 & 0,267 & & \\
\hline & $\mathrm{A}_{2} \mathrm{~A}_{2}$ & 0,069 & 0,067 & 0,333 & $19,93 * *$ & 4 \\
\hline
\end{tabular}


A variação nas frequiências alélicas entre os diferentes grupos pode ter várias origens, tais como: migração, mutação, seleção e deriva genética. A migração de indivíduos de outras populações, a partir de sementes, ou através de pólen, poderia facilmente causar alterações nas freqüências alélicas dos diferentes grupos. Infelizmente, como não se tem dados genéticos de outras populações potencialmente aptas a troca de genes com em estudo, não é possível testar esta hipótese. Da mesma forma, a presença de mutação também não é possível de ser testada, devido a natureza do delineamento experimental.

No caso da seleção, a deteç̧ão de sua presença fere um dos pressupostos básicos dos marcadores bioquímicos (isoenzimas), que sua natureza é neutra, portanto não conferem nenhuma vantagem seletiva. Esta teoria, já há muito tempo vem criando polêmica, sendo que até existem dois grupos de cientistas de opiniões divergentes, os neutralistas e os selecionistas, ou a hipótese do balanceamento e a clássica (Futuyma, 1992). Até este momento, não se sabe exatamente qual dos grupos tem a razão, ou se ela realmente existe. Dessa forma, poderia-se especular, no caso da seleção, dizendo que os locos isoenzimáticos estariam ligados a locos que estão sob forte seleção. A seleção poderia atuar em dois sentidos, a favor de alelos favoráveis ou a favor de combinações genotípicas específicas. A hipótese de seleção para alelos favoráveis só seria satisfeita para os locos Skdh-1 e Pgi-1, nos quais as freqüências alélicas na Tabela 8 mostram um aumento gradual da frequiência do alelo q, da fase de plântula para a fase adulta. Concordantemente, a hipótese de seleção para genótipos específicos seria satisfeita para estes mesmos locos, Skdh-1 e Pgi-1. De acordo com as frequiências genotípicas (Tabela 10) desses locos, a seleção estaria atuando em favor dos genótipos homozigotos do tipo $\mathrm{A}_{2} \mathrm{~A}_{2}$.

Entretanto, este conjunto de dados não permite afirmar com certeza se está ocorrendo seleção, entre a fase de plântula e a fase adulta. Os dados obtidos, de forma geral, sugerem muito mais a presença de deriva genética. A 
hipótese de deriva genética, seria explicada para quatro dos seis locos polimórficos avaliados, Mdh-1, Prx-2, 6Pgdh-1 e Lap-2, onde as frequiências dos alelos oscilou de grupo para grupo. Por exemplo, o alelo $\mathrm{p}$ no loco Mdh-1 aumentou sua freqüência de 0,200 no grupo de plântulas para 0,250 no grupo de jovens, vindo a cair para 0,217 no grupo de adultos. Nesse mesmo loco o alelo $r$ baixou sua frequiência de 0,485 nas plântulas para 0,450 nos jovens, vindo a subir para 0,550 nos adultos. Outro exemplo, seria o do alelo mais freqüente no loco Prx-2; nesse o alelo p foi o mais freqüente no grupo de plântulas e jovens e o alelo $r$ no grupo de adultos. Nos locos 6Pgdh-1 e Lap-2, também tem-se fortes evidências de deriva genética entre os grupos, onde o alelo $\mathrm{p}$ aumentou sua freqüência do grupo de plântulas para jovens, vindo a decrescer para uma freqüência próximo a meio no grupo de adultos. A deriva pode ter origem no tamanho amostral utilizado para caracterizar os grupos, ou ser intrínseca à própria natureza da população, devido a eventos casuais, tais como seu histórico de colonização, extinção, predação, emigração, entre outros.

Os resultados mostram que as maiores divergências encontram-se entre a fase de jovem e adultos, a considerar pela magnitude do $\hat{F}_{\text {ST }}$. Possivelmente, isso ocorre devido a ser uma fase bem mais longa que a fase entre plântulas e jovens. Indivíduos entre a fase de jovens e adultos estariam mais sujeitos à deriva genética, devido a eventos casuais como, catástrofes ambientais, processos intrínsecos a dinâmica da floresta, como abertura de clareiras, causando a morte de um grande número de indivíduos jovens no subbosque ou permitindo o desenvolvimento de alguns indivíduos, pela maior disponibilidade de luz.

Um outro ponto a ser considerado na hipótese de deriva seria que o número de indivíduos na fase de plântula é maior que o número de indivíduos jovens, que por sua vez é maior que o número de indivíduos adultos. Considerando que a amostragem aqui realizada não respeitou esta "pirâmide 
social", caracterizando os jovens e os adultos com um mesmo tamanho amostral $(\mathrm{N}=30)$, isso poderia ter causado deriva devido à amostragem ineficiente dos indivíduos jovens. Especulando esta possibilidade e comparando as freqüências alélicas apenas entre plântulas e adultos, desprezando-se os jovens, tem-se indicativos da presença de seleção em favor de alelos em todos os locos polimórficos. No loco Mdh-1 os alelos p e r estariam sendo favorecidos, no loco Prx-2 o alelos $r$ seria o favorecido e nos locos 6Pgdh-1, Skdh-1, Pgi-1 e Lap-2 o alelo q seria o favorecido. Da mesma forma, as frequiências genotípicas na Tabela 9 indicariam que certos genótipos são mais favoráveis ao ambientes ciliar. Por exemplo, nos locos Mdh-1 e Prx-2, os genótipos mais favoráveis seriam os homozigotos do tipo $A_{1} A_{1}$ e $A_{3} A_{3}$, bem como o heterozigoto de seu cruzamento $\mathrm{A}_{1} \mathrm{~A}_{3}$, para o loco Mdh-1. Nesse caso parece que a seleção está mais associada ao efeito dos alelos que de sua combinação em si. No loco 6Pgdh-1, ambos os genótipos homozigotos $\left(A_{1} A_{1}, A_{2} A_{2}\right)$ estariam sendo favorecidos, em detrimento do heterozigoto $\left(A_{1} A_{2}\right)$. Nos locos Skdh-1, Pgi-2 e Lap-2, o genótipo homozigoto do tipo $A_{2} A_{2}$ parece ser o mais vantajoso, seguido pelo homozigoto $A_{1} A_{1}$, sendo o heterozigoto desfavorecido.

A hipótese de seleção contra heterozigotos parece, à primeira vista, um tanto incoerente, ainda mais se considerarmos muitos dos trabalhos na literatura que postulam justamente o contrário, seleção em favor de heterozigotos. Sempre se pensa nas vantagens do heterozigoto, que carrega dois alelos diferentes, aumentando a plasticidade genética das espécies. Contudo, dado que o $C$. brasiliense ocorre em um ambiente restrito, a seleção poderia estar ocorrendo favorecendo os alelos ou combinações genotípicas mais favoráveis a esse ambiente. Segundo Kimura (1982), mesmo sendo os alelos neutros equivalentes. funcionalmente para as espécies sob um grupo de condições ambientais determinadas, é possível que alguns deles possam ser selecionados, quando novas condições ambientais são impostas, ou seja, alelos neutros têm um potencial 
latente para a seleção, e mutações neutras podem ser uma matéria prima para a evolução adaptativa. Assim, poderia se pensar que, de modo geral, os genótipos homozigotos estão sendo favorecidos pelo ambiente para o estabelecimento na população. Contudo, deve ter-se em mente que os grupos foram caracterizados geneticamente de forma fragmentada ou não seqüencialmente, ou seja, as plântulas não deram origem aos jovens e nem estes aos adultos. Na verdade, uma grande parte das plântulas e dos jovens deve ter sido originado do cruzamento entre os adultos.

A melhor hipótese para a variação nas frequiências alélicas entre os grupos seria que os adultos deram origem ao maior número de plântulas, possivelmente com a contribuição do fluxo de genes via pólen, de outra populações. Isto parece ficar mais plausível, quando observa-se na Tabela 10 que as frequiências genotípicas dos indivíduos adultos homozigóticos tenderam a ser maior em quase todos os locos, com exceção do locos 6Pgdh-1. Da mesma forma, a freqüência genotípica nas plântulas tendeu a apresentar maiores valores para os genótipos heterozigotos. Isto poderia ter ocorrido facilmente do cruzamento entre os indivíduos adultos homozigóticos, resultando em progênies segregantes.

Em resumo, plantas adultas homozigotas divergentes (ex: $A_{1} A_{1}$, $A_{2} A_{2}$ e $A_{3} A_{3}$ ) devido possivelmente a um efeito fundador ou à seleção, estariam dando origem a progênies (refletido nas plântulas) heterozigóticas, que possivelmente estariam submetidas a forte seleção natural para o ambiente de galeria (solos hidromórficos). 


\section{3 Índices de Diversidades Genética}

A Tabela 11 mostra que, nos 3 grupos de $C$. brasiliense, as estimativas dos parâmetros de diversidade genética são muito semelhantes entre si e estão em torno das médias das populações de espécies arbóreas já estudas.

A heterozigosidade observada (Ho) desta população de $C$. brasiliense, considerando todos os locos, foram, respectivamente, para plântulas, jovens e adultos, de $0,191 \pm 0,068 ; 0,138 \pm 0,055$ e $0,141 \pm 0,054$. Verifica-se que a maior parte da variabilidade genética se encontra dentro do grupo de plântulas. A diversidade genética ou heterozigosidade esperada $(\mathrm{He})$ foi maior que a $\mathrm{Ho}$, mostrando o excesso de homozigoto. Porém, esses valores não são estatisticamente diferentes entre si, a julgar pelo seu erro padrão da média.

Hamrick \& Godt (1990), em uma revisão de 653 estudos de diversidade genética por isoenzimas com 449 espécies de plantas, encontraram uma diversidade genética média ao nível populacional de 0,160 para gimnospermas, 0,149 para espécies arbóreas, 0,159 para espécie de ampla distribuição, 0,109 para espécies tropicais, 0,124 para espécies de polinização por animais e 0,123 para espécie com dispersão pelo vento. Pode-se observar que a diversidade genética desta população nas plântulas foi superior às médias de todos estes casos e, nos jovens e adultos, manteve-se um pouco mais baixa quando comparada às médias de espécies arbóreas e de ampla distribuição

No entanto, valores mais elevados ocorrem em algumas espécies. Em Bauhinia forficata, Santos (1994) encontrou o valor de 0,451 para heterozigosidade em uma população natural. Já, Murawski \& Bawa (1994) encontraram em Stemonoporus oblongifolius uma heterozigosidade média por população de 0,282. Hamrick \& Loveless (1989) encontraram para 16 espécies

arbóreas tropicais, que ocorrem com alta densidade, uma heterozigosidade média de 0,211 , sendo este valor superior ao encontrado em C. brasiliense, neste estudo. 
Tabela 11: Variabilidade genética de uma população de $C$. brasiliense com base em 14 locos e 8 sistemas enzimáticos (os valores entre parênteses equivalem ao erro padrão da média). Piracicaba, ESALQ/USP, 1999.

\begin{tabular}{llll}
\hline & Plântulas & Jovens & Adultos \\
\hline Tamanho da amostra & 100 & 30 & 30 \\
Número médio de alelos por loco & $1,71(0,24)$ & $1,57(0,20)$ & $1,64(0,20)$ \\
Porcentagem de locos polimórficos $(0,95)$ & 42,86 & 42,86 & 42,86 \\
Heterozigozidade média observada $\left(\mathrm{H}_{0}\right)$ & $0,191(0,068)$ & $0,138(0,055)$ & $0,141(0,054)$ \\
Heterozigosidade média esperada $\left(\hat{H}_{\mathrm{c}}\right)$ & $0.208(0.070)$ & $0,187(0,065)$ & $0.223(0,072)$ \\
\hline
\end{tabular}

Em espécies de baixas densidades ou raras, que podem apresentam altos índices de autofecundação, os valores de heterozigosidade são menores do que aqueles encontrados em espécies comuns. Hamrick \& Murawski (1991) conduziram um estudo com 16 espécies arbóreas tropicais que ocorrem a baixa densidade (de 1 indivíduo a cada 2 ha a 1 indivíduo a cada 10 ha) e obtiveram uma heterozigosidade média de 0,124.

Mesmo não estando fora dos valores de médias observados para espécies comuns, $C$. brasiliense apresenta valores inferiores do que os esperados para a mesma, estando mais próximos das médias encontradas para espécies raras, podendo ser um caso intermediário, ou seja, uma espécie comum em ambiente restrito.

Os valores de porcentagem de locos polimóficos encontrados nas 16 espécies comuns, citadas anteriormente, foram de $(77 \%)$ e das 16 espécies raras de $(42 \%)$. C. brasiliense apresentou novamente valores semelhantes às espécies raras $(42,86 \%)$. Mesmo assim, esse polimorfismo não é considerado baixo quando comparado a índices de outras espécies. Comparando-se a magnitude 
desse índice ao encontrado para espécies vegetais, 36\% (Hamrick et al. 1979) e $50 \%$ (Hamrick \& Godt, 1990), pode-se considerar que a população de $C$. brasiliense apresenta um polimorfismo médio.

O número médio de alelos por loco foi baixo e variou pouco entre plântulas $(1,71 \pm 0,24)$, jovens $(1,57 \pm 0,20)$ e adultos $(1,64 \pm 0,20)$. Para esta estimativa considerou-se todos os locos, monomórficos e polimórficos, e como grande parte dos locos eram monomórficos, o valor estimado apresentou-se baixo. Segundo Nei (1977), esta estatística é muito influenciada pelo tamanho da amostragem genética (número de locos), por isso não é uma boa medida de variabilidade genética para comparação entre amostras de tamanhos diferentes.

Na Tabela 12, observa-se valores de $\hat{f}$ (índice de fixação) para os locos polimórficos de plântulas, jovens e adultos de $C$. brasiliense. Apenas os locos Mdh-1 e 6Pgdh-1 das plântulas e jovens e 6Pgdh-1 dos adultos, o $\hat{f}$ foi negativo indicando excesso de heterozigotos, nos demais locos, os valores de $\hat{f}$ foram altos e positivos, mostrando excesso de homozigotos, ou seja, endogamia.

Tabela 12: Índice de Fixação $(\hat{f})$ para 3 grupos de $C$. brasiliense, locos polimórficos. Piracicaba, ESALQ/USP, 1999.

\begin{tabular}{lccc}
\hline Loco & Plântulas & Jovens & Adultos \\
\hline Mdh-1 & $-0,023 \mathrm{~ns}$ & $-0,034 \mathrm{~ns}$ & $0,105 \mathrm{~ns}$ \\
Prx-2 & $0,139 \mathrm{~ns}$ & $0,051 \mathrm{~ns}$ & $0,370^{*}$ \\
6pgdh-1 & $-0,258^{*}$ & $-0,002 \mathrm{~ns}$ & $-0,101 \mathrm{~ns}$ \\
Skdh-1 & $0,191 \mathrm{~ns}$ & $0,394^{*}$ & $0,634^{* *}$ \\
Pgi-1 & $0,342^{* *}$ & $0,722^{* *}$ & $0,733^{* *}$ \\
Lap-1 & $0,204^{*}$ & $0,423 *$ & $0,469^{*}$ \\
\hline Média & $0,084(0,159) \mathrm{ns}$ & $0,264(0,255)^{* *}$ & $0,372(0,241)^{* *}$ \\
\hline
\end{tabular}

Significância: Bootstrapping sobre locos, 10.000 repetições; ns: não significativo; *: 5\%; **: $1 \%$ 
Com relação à média dos locos, o $\hat{f}$ apresentou valores positivos, sugerindo endogamia. $\mathrm{O}$ grupo de indivíduos adultos mostrou-se mais endogâmico que o grupo de jovens e plântulas, respectivamente.

Os valores de $\hat{f}$ mais positivos para adultos do que para plântulas (considerando que essas plântulas sejam as descendentes dos adultos) são diferentes dos normalmente encontrados, pois são contrastantes com outros trabalhos de espécies arbóreas tropicais. Como por exemplo, Beichmedia pendula (Murawski \& Hamrick, 1991), Shorea megistophylla (Murawski et al., 1994), Astrocaryum mexicanum (Eguiarte et al., 1992), Pithecellobion pedicellare (O`Malley \& Bawa, 1987), Cecropia obtusifolia (Alvarez-Buylla \& Garay, 1994), dentre outros, todas com $\hat{f}$ menores ou negativos nos adultos quando comparados às progênies. No entanto, valores de $\hat{f}$ mais altos para adultos e menores para progênies são raros, já foram apontados em Couratari guianenses e Couratari multiflora (Lepsch-Cunha, 1996) e em Trichilia tuberculata (Murawisk \& Hamrick, 1991).

Esses resultados em $C$. brasiliense possivelmente podem ser explicados pelo efeito de estrangulamento e aumento populacional (Nei et al., 1975) concomitante com o modelo de migrantes (Slatkin, 1977), e podem ser consistentes com a seguinte hipótese: a presença de excesso de homozigotos (endogamia) pode ser resultante do processo de fundação, ocorrido ou por redução populacional ou colonização da área por poucos indivíduos (efeito fundador). A eliminação dos homozigotos com o tempo pode estar ocorrendo pelo aumento populacional e pelo fluxo gênico via pólen e sementes a longas distâncias, que restaurariam a diversidade genética.

A alta homozigose encontrada nos indivíduos adultos parece ser devido a área em estudo ser possivelmente nova, em termos de colonização. Este fato pode ser explicado pela presença de espécies como Talauma ovata, Tabebuia 
umbelata e Tapirira guianensis, que apresentam síndrome de colonizadoras de áreas novas, estas espécies estão entre as 10 primeiras com maior IVI na área estudada (Schiavini, 1992). A espécie estudada pode estar colonizando o local recentemente, tendo sido fundada por população de indivíduos pequena. Assim sendo, o aumento da heterozigosidade nas plântulas, em relação aos adultos, pode ser explicado pelo aumento de indivíduos advindos de outras áreas, expandindo a floresta. A comparação das estimativas de adultos e plântulas quanto aos índices de fixação indicam que a espécie está adaptada à oscilação populacional, já que os mais jovens contém mais heterozigosidade.

Um outro fator, que pode explicar a maior homozigose nos indivíduos adultos, é o fato da possível ocorrência de seleção de plântulas para o estabelecimento de indivíduos adultos. Esta hipótese pode ser explicada devido à ocorrência de indivíduos adultos de C. brasiliense, na área estudada, apenas onde o solo é hidromórfico (saturado de água) a maior parte do ano (Schiavini, 1992).

Sabe-se que as isoenzimas são marcadores neutros que não sofrem seleção, mas possivelmente os genes que estão sofrendo seleção podem estar em locos muito próximos dos locos isoenzimáticos, ou seja, com ligação. O loco que sofre seleção para uma melhor adaptação ao ambiente restrito de estabelecimento da espécie (saturado de água) está levando o loco isoenzimático junto, desta forma, segregando de forma igual. Assim sendo, ao invés de estar sendo selecionados genótipos heterozigotos, estão sendo selecionados os homozigotos, pois estes poderão ser os mais adaptados ao ambiente saturado de água. Homozigotos podem ter valor adaptativo maior que os heterozigotos, isso ocorre quando os homozigotos são adaptados a diferentes meios, mas os heterozigotos a nenhum deles (Futuyma, 1992).

Uma terceira forma de explicar a maior endogamia nos indivíduos adultos é que cruzamentos entre indivíduos homozigotos geram indivíduos heterozigotos, refletido nas plântulas. 
Em resumo, os adultos dessa espécie não apresentaram índices de fixação menores que as plântulas, refletindo a ausência da seleção no sentido da eliminação de homozigotos (Lepsch-Cunha, 1996). No entanto, a maioria das outras espécies da florestas tropical, já apontada anteriormente, apresentam redução nos índices de fixação dos adultos com relação às progênies. Os autores em geral sugerem seleção a favor de heterozigotos (Equiarte et al., 1992) e, neste caso, endogamia aumentada deve ser importante no sentido da conservação dessas espécies, podendo ocasionar problemas de depressão endogâmica pelo aumento dos genótipos homozigotos (Lepsch-Cunha, 1996). Podendo estar acorrendo também o aparecimento de apomixia, sendo que, nesse caso. a agamospermia parece ser uma estratégia populacional para manutenção da variabilidade genética existente. Ela aumenta a proporção dos genótipos já existentes, ou seja, a apomixia facultativa pode conter o efeito da depressão endogâmica e deriva genética através do prolongamento e aumento do número de genótipos e, consequentemente, conservar a heterozigosidade advinda da reprodução sexuada (Murawski, 1995).

\subsection{Aderência ao Equilíbrio de Hardy - Weinberg}

Nas Tabelas 13, 14 e 15 são apresentados os testes de $\chi^{2}$ para verificação dos desvios das frequiências genotípicas observadas, com relação às frequiências genotípicas esperadas, sob o modelo do Equilíbrio de HardyWeinberg (EHW). 
Tabela 13: Verificação da aderência das estimativas encontradas para 6 locos polimórficos ao modelo do Equilíbrio de Hardy - Weinberg, através dos testes do $\chi^{2}$ para o grupo de plântulas de $C$. brasiliense. Piracicaba - SP, ESALQ/USP, 1999.

\begin{tabular}{|c|c|c|c|c|c|c|}
\hline Loco & Genótipos & $\mathrm{n}_{\mathrm{o}}$ & $n_{e}$ & $\chi^{2}$ & GL & $\mathrm{P}$ \\
\hline \multirow{6}{*}{ Mdh-1 } & $1-1$ & 8 & 4,00 & $10,87^{*}$ & 3 & 0,013 \\
\hline & $1-2$ & 13 & 12,6 & & & \\
\hline & $1-3$ & 11 & 19,4 & & & \\
\hline & $2-2$ & 5 & 9,92 & & & \\
\hline & $2-3$ & 40 & 30.55 & & & \\
\hline & $3-3$ & 23 & 23,522 & & & \\
\hline \multirow[t]{3}{*}{$\operatorname{Prx}-2$} & 1 & 30 & 26,010 & $2,09 \mathrm{~ns}$ & 1 & 0,15 \\
\hline & 2 & 42 & 49,980 & & & $\#$ \\
\hline & 3 & 28 & 24,010 & & & \\
\hline \multirow[t]{3}{*}{ 6Pgdh } & 1 & 26 & 32,000 & $5,38 \mathrm{~ns}$ & 1 & 0.20 \\
\hline & 2 & 60 & 48,000 & & & $\#$ \\
\hline & 3 & 12 & 18,000 & & & \\
\hline \multirow[t]{3}{*}{ Skdh-1 } & $1-1$ & 30 & 26,633 & $1,58 \mathrm{~ns}$ & 1 & 0,21 \\
\hline & $1-2$ & 39 & 45,734 & & & \\
\hline & $2-2$ & 23 & 19,633 & & & \\
\hline \multirow[t]{3}{*}{ Pgi-1 } & 1 & 65 & 58,522 & $11,39 * *$ & 1 & 0,001 \\
\hline & 2 & 23 & 35,955 & & & \# \\
\hline & 3 & 12 & 5,523 & & & \\
\hline \multirow[t]{3}{*}{ Lap-2 } & $1-1$ & 70 & 66,423 & $4,38^{*}$ & 1 & 0,052 \\
\hline & $1-2$ & 23 & 30,155 & & & @ \\
\hline & $2-2$ & 7 & 3,422 & & & \\
\hline
\end{tabular}

$\mathrm{n}_{\mathrm{v}}$ - número observado: $\mathrm{n}_{\mathrm{e}}$ - número esperado: GL - graus de liberdade: $\mathrm{P}$ - probabilidade de ajuste para a istribuição dos $\chi^{2}: *$ P.0.05 e **P.0.01: ns - não significativo: @ - P PISCHER: \#: Teste agrupado 
Tabela 14: Verificação da aderência das estimativas encontradas para 6 locos polimórficos ao modelo do Equilíbrio de Hardy - Weinberg, através dos testes do $\chi^{2}$ para o grupo de jovens de $C$. brasiliense. Piracicaba - SP, ESALQ/USP, 1999.

\begin{tabular}{|c|c|c|c|c|c|c|}
\hline Loco & $\begin{array}{l}\text { Genótipos } \\
\text { ou classes }\end{array}$ & $\mathrm{n}_{\mathrm{o}}$ & $n_{e}$ & $\chi^{2}$ & $\mathrm{GL}$ & $\mathrm{P}$ \\
\hline \multirow[t]{3}{*}{ Mdh-1 } & 1 & 7 & 6,075 & $0,172 \mathrm{~ns}$ & 1 & 0,678 \\
\hline & 2 & 13 & 14,850 & & & \# \\
\hline & 3 & 7 & 9.075 & & & \\
\hline \multirow[t]{3}{*}{ Prx-2 } & 1 & 16 & 16,133 & $0,00 \mathrm{~ns}$ & 1 & 1,0 \\
\hline & 2 & 12 & 11,733 & & & \# \\
\hline & 3 & 2 & 2,133 & & & \\
\hline \multirow{3}{*}{ 6Pgdh-1 } & $1-1$ & 20 & 20,008 & $0,00 \mathrm{~ns}$ & 1 & 1,0 \\
\hline & $1-2$ & 9 & 8.983 & & & (a) \\
\hline & $2-2$ & 1 & 1,008 & & & \\
\hline \multirow[t]{3}{*}{$\overline{\text { Skdh-1 }}$} & $1-1$ & 9 & 6,075 & $3,54 \mathrm{~ns}$ & 1 & 0,06 \\
\hline & $1-2$ & 9 & 14,850 & & & \\
\hline & $2-2$ & 12 & 9,075 & & & \\
\hline \multirow[t]{3}{*}{ Pgi-1 } & $1-1$ & 16 & 11,408 & $10,58 * *$ & 1 & 0,00 \\
\hline & $1-2$ & 4 & 14,183 & & & (a) \\
\hline & $2-2$ & 10 & 4.408 & & & \\
\hline \multirow[t]{3}{*}{ Lap-2 } & $1-1$ & 24 & 22,533 & $2,65 \mathrm{~ns}$ & 1 & 0,058 \\
\hline & $1-2$ & 4 & 6,933 & & & (a) \\
\hline & $2-2$ & 2 & 0,533 & & & \\
\hline
\end{tabular}

$\mathrm{n}_{\mathrm{o}}$ - número observado: $\mathrm{n}_{\mathrm{e}}$ - número esperado: $\mathrm{GL}$ - graus de liberdade:

P - probabilidade de ajuste para a distribuição dos $\chi^{2}: *$ P.0.05 e **P.0.01

ns - não significativo: @ - P FISCHER: \#: Teste agrupado 
Em alguns locos de plântulas, jovens e adultos, foi considerado mais seguro o uso do teste exato de Fisher para testar os desvios do EHW, como nos locos Prx-2, 6Pgdh-1 e Pgi-1 das plântulas, Mdh-1 e Prx-2 dos jovens e Mdh-1 e Prx-2 dos adultos, devido à ocorrência de classes com valores inferiores a 5.

Nas plântulas, 3 locos (Mdh-1, Pgi-1 e Lap-2) rejeitaram a hipótese nula e 3 locos (Prx-2, 6pgdh-1 e Skdh-1) apresentaram-se nas proporções do EHW. Para os indivíduos jovens, 5 locos (Mdh-1, Prx-2, 6pgdh-1, Skdh-1 e Lap2) apresentaram- se em EHW pelo teste do $\chi^{2}$ e 1 rejeitou a hipótese nula (Pgi-1). Para os indivíduos adultos, a hipótese nula de adequação ao modelo do EHW foi rejeitada em 3 locos ( Skdh-1, Pgi-1e Lap-2) e 3 apresentaram-se em EHW (Mdh1. Prx-2 e 6pgdh).

Desvios do EHW podem estar associados a fatores, como deriva genética, seleção, mutação ou tamanho finito da população e não propriamente ao sistema reprodutivo/endogamia (Sebbenn, 1997). Desta forma, é importante testar se os locos que não se adequaram ao modelo proposto por Hardy- Weinberg estão em equilíbrio de endogamia de Wright (EEW), o qual separa a endogamia, devido ao sistema misto de reprodução, do ef eito de outros fatores não ligados ao sistema reprodutivo. A adequação dos dados ao modelo de Wright pressupõe endogamia gerada por autofecundação e/ou acasalamentos entre aparentados (Sebbenn, 1997).

Apenas o loco Mdh-1 nas plântulas (Tabela 16) pode ser submetido ao teste de endogamia de Wright (EEW). Os demais locos que não se apresentaram em EHW, não puderam ser testados quanto à adequação ao modelo do EEW, devido aos graus de liberdade terem sido insuficientes para a realização do teste. 
Tabela 15: Verificação da aderência das estimativas encontradas para 6 locos polimórficos ao modelo do Equilíbrio de Hardy - Weinberg, através dos testes do $\chi^{2}$ para o grupo de adultos de $C$. brasiliense . Piracicaba - SP, ESALQ/USP, 1999.

\begin{tabular}{|c|c|c|c|c|c|c|}
\hline Loco & $\begin{array}{l}\text { Genótipos } \\
\text { ou classe }\end{array}$ & $\mathrm{N}_{\mathrm{o}}$ & $\mathrm{n}_{\mathrm{e}}$ & $\chi^{2}$ & GL & $\mathrm{P}$ \\
\hline \multirow[t]{3}{*}{ Mdh } & 1 & 10 & 9,075 & $0,172 \mathrm{~ns}$ & 1 & 0,678 \\
\hline & 2 & 13 & 14,850 & & & \# \\
\hline & 3 & 7 & 6,075 & & & \\
\hline \multirow[t]{3}{*}{$\operatorname{Pr} x-2$} & 1 & 10 & 8.008 & $3.668 \mathrm{~ns}$ & 1 & 0.055 \\
\hline & 2 & 10 & 14,983 & & & $\#$ \\
\hline & 3 & 10 & 7,008 & & & \\
\hline \multirow{3}{*}{ 6Pgdh } & $1-1$ & 7 & 7,594 & $0,043 \mathrm{~ns}$ & 1 & 0.836 \\
\hline & $1-2$ & 13 & 11,813 & & & \\
\hline & $2-2$ & 4 & 4,594 & & & \\
\hline \multirow[t]{3}{*}{ Skdh } & $1-1$ & 8 & 3,675 & $10,00 * *$ & 1 & 0,001 \\
\hline & $1-2$ & 5 & 13,650 & & & @ \\
\hline & $2-2$ & 17 & 12,675 & & & \\
\hline \multirow[t]{3}{*}{ Pgi } & $1-1$ & 13 & 7,500 & $14,02 * *$ & 1 & 0,0 \\
\hline & $1-2$ & 4 & 15,000 & & & @ \\
\hline & $2-2$ & 13 & 7,500 & & & \\
\hline \multirow[t]{3}{*}{ Lap-2 } & $1-1$ & 12 & 8,533 & $5,15^{*}$ & 1 & 0,023 \\
\hline & $1-2$ & 8 & 14,933 & & & \\
\hline & $2-2$ & 10 & 6,533 & & & \\
\hline
\end{tabular}

$\mathrm{n}_{\mathrm{o}}$ - número observado: $\mathrm{n}_{\mathrm{e}}$ - número esperado; $\mathrm{GL}$ - graus de liberdade;

$\mathrm{P}$ - probabilidade de ajuste para a distribuição dos $\chi^{2}: *$ * .0 .05 e **P,0.0 ]

ns - não significativo: @ - P FISCHER: \#: Teste agrupado 
Tabela 16: Teste de equilíbrio de endogamia de Wright (EEW), para o loco Mdh1 de plântulas de $C$. brasiliense. ESALQ/USP, 1999.

\begin{tabular}{cccc}
\hline Classe & no & Ne & $\chi^{2}$ \\
\hline A1A1 & 8 & 4,1 & 3,78 \\
A1A2 & 13 & 11,7 & 0,15 \\
A1A3 & 11 & 14,2 & 1,58 \\
A2A2 & 5 & 16,0 & 5,93 \\
A2A3 & 40 & 31,3 & 2,44 \\
A3A3 & 23 & 22.8 & 0.00 \\
& 100 & 100 & $13,89 * *$ \\
& & & $\mathrm{GL}=2$ \\
\hline
\end{tabular}

** significativo a $1 \%$ de probabilidade.

\subsection{Tamanho Efetivo $\left(\hat{N}_{c}\right)$}

O tamanho efetivo para os grupos foi calculado considerando as espécie como hermafroditas e dióicas. Partindo do princípio que as frequêencias alélicas não são diferentes entre machos e fêmeas (proporção de 1:1), não existem diferenças entre as estimativas de $\hat{N}_{\iota}$ como dióicas e hermafroditas. Assim sendo, serão apresentados na Tabela 17 apenas os resultados que consideram $C$. brasiliense como hermafroditas, já que os resultados que consideram a espécie como sendo dióica serão os mesmos. Os cálculos foram baseados na metodologia proposta por Vencovsky (1992), para plantas hermafroditas. 
Tabela 17: Componentes de variâncias a nível de média de locos para todos os Gupos, Plântulas, Jovens e Adultos, e $\hat{N}_{e}, \hat{N}_{e} \%$ e $\hat{f}$. Considerando $C$. brasiliense como hermafrodita. Piracicaba- SP, ESALQ/USP. 1999.

\begin{tabular}{|c|c|c|c|c|c|c|c|c|c|c|c|c|}
\hline & \multicolumn{3}{|c|}{ Todos os Grupos } & \multicolumn{3}{|c|}{ Plântulas } & \multicolumn{3}{|c|}{ Jovens } & \multicolumn{3}{|c|}{ Adultos } \\
\hline & A & B & $\mathrm{C}$ & $\mathrm{A}$ & B & $\mathrm{C}$ & A & $\mathrm{B}$ & $\mathrm{C}$ & A & B & $\mathrm{C}$ \\
\hline$\hat{\sigma}_{g}^{2}$ & 2,4000 & 320 & 0,0075 & - & & & & & & - & & \\
\hline$\hat{\sigma}_{I / G}^{2}$ & 0,5027 & 160 & 0,0031 & 2,6744 & 200 & 0,0134 & 1,9333 & 60 & 0,0322 & 1,9750 & 60 & 0.0329 \\
\hline$\hat{\sigma}_{G}^{2}$ & 0,1528 & 3 & 0,0509 & 0,2452 & 100 & 0,0025 & 0,6943 & 30 & 0,0231 & 1,1693 & 30 & 0,0390 \\
\hline$\hat{\sigma}_{T}^{2}$ & 3,0555 & & 0.0616 & 2,9196 & & 0,0158 & 2.6276 & & 0,0554 & 3,1443 & & 0,0719 \\
\hline $\mathrm{N}$ & & & 160 & & & 100 & & & 30 & & & 30 \\
\hline$\hat{N}_{e}$ & & & 24,8 & & & 92,2 & & & 23,7 & & & 21,9 \\
\hline$\hat{\Lambda}_{e}(\%)$ & & & 15,50 & & & 92,25 & & & 79,10 & & & 72,89 \\
\hline$\hat{f}$ & & & 0,173 & & & 0.082 & & & 0,239 & & & 0,377 \\
\hline
\end{tabular}

$\hat{\sigma}_{g}^{2}=$ componentes de variâncias entre genes; $\hat{\sigma}_{I / G}^{2}=$ componentes entre variâncias de indivíduos /grupos;

$\hat{\sigma}_{G}^{2}=$ componentes de variância de grupos; $\hat{\sigma}_{T}^{2}=$ componentes total de variância de indivíduos: $A=$ estimativa de componentes de variância; $B=$ número de indivíduos; $C=A \sqrt{ }=$ variância média de cada componente.

A partir da estimativa de $\hat{N}_{e}$ para todos os grupos, plântulas, jovens e adultos (Tabela 17), pode-se afirmar que, no conjunto, os 160 indivíduos (N) analisados representam em média geneticamente 24,8 indivíduos que poderiam estar se acasalando (se todos os indivíduos fossem adultos reprodutivos). Nas plântulas 100 indivíduos analisados representam geneticamente 92,25 indivíduos que poderiam estar se acasalando (se fossem adultos reprodutivos), nos jovens 30 indivíduos analisados representam geneticamente 23,73 indivíduos que poderiam 
estar acasalando e nos adultos 30 indivíduos analisados representam geneticamente 21,87 indivíduos que estão se acasalando.

Como o $\hat{N}_{e}$ foi aqui diferente possivelmente em função de deriva genética, poderia-se interpretar este resultado, ainda como, que os 160 indivíduos avaliados na população representam aproximadamente 25 plantas de uma população infinita que esteja sofrendo a mesma quantidade de deriva genética.

Da mesma forma, significa que as 100 plântulas, os 30 jovens e os 30 adultos representam 92, 23 e 22 indivíduos de uma população infinita que apresenta a mesma deriva genética. Verifica-se, assim, que a representatividade genética dos grupos é próxima daquelas que poderiam ser obtidas em uma população panmítica, e, portanto, que a deriva genética é baixa, podendo, as variações nas freqüências alélicas serem atribuídas mais ao sistema reprodutivo, como pode ser observado pelo índice de fixação, ou seja, quanto maior of menor é a representatividade. No caso da análise da população, considerando todos os grupos conjuntamente, a baixa representatividade estaria associada à deriva genética amostral entre os grupos. Isto é confirmado pela superioridade na $\hat{\sigma}_{G}^{2}$ média (Coluna $\mathrm{C}$ ) a qual foi o componente que contribuiu mais para a $\hat{\sigma}_{T}^{2}$.

De acordo com os resultados obtidos, observa-se que quanto maior a endogamia, menor é a representatividade em relação ao tamanho efetivo. O tamanho efetivo é reduzido quando existe deriva, cruzamento entre aparentados e endogamia como observado em C. brasiliense.

Se for feita uma simulação mudando as proporções sexuais de 1:1 para 1:2 e 1:3, os resultados obtidos serão diferentes para dióica a estimativa de espécies como quando comparada a hermafrodita (Tabela 18). Verifica-se que o tamanho efetivo é otimizado quando a proporção sexual é 1:1, sendo que quanto maior a diferença entre esta proporção, menor será o tamanho efetivo. 
O tamanho efetivo populacional é um parâmetro muito importante a ser conhecido nas atividades de preservação de germoplasma, coleta de sementes e conservação in situ, uma vez que trata da representatividade genética das amostras.

Tabela 18. Simulação do tamanho efetivo de $C$. brasiliense, considerando as proporções sexuais de machos $(M)$ e fêmeas $(F)$ diferentes [1 macho para 1 fêmea (1:1), 1 macho para 2 fêmeas (1:2) e 1 macho para 3 fêmeas (1:3)]. Piracicaba- SP, ESALQ/USP, 1999.

\begin{tabular}{|c|c|c|c|c|c|c|c|c|c|c|c|c|c|c|c|c|c|}
\hline & \multicolumn{5}{|c|}{$1: 1$} & \multicolumn{6}{|c|}{$1: 2$} & \multicolumn{6}{|c|}{$1: 3$} \\
\hline & Plântula & \multicolumn{2}{|c|}{ Jovens } & \multicolumn{2}{|c|}{ Adultos } & \multicolumn{2}{|c|}{ Plântula } & \multicolumn{2}{|c|}{ Jovens } & \multicolumn{2}{|c|}{ Adultos } & \multicolumn{2}{|c|}{ Plântula } & \multicolumn{2}{|c|}{ Jovens } & \multicolumn{2}{|c|}{ Adultos } \\
\hline & $M \quad F$ & $\mathrm{M}$ & $\mathrm{F}$ & M & $\mathrm{F}$ & M & $\mathrm{F}$ & $\mathrm{M}$ & $\mathrm{F}$ & $\mathrm{M}$ & $\mathrm{F}$ & $\mathrm{M}$ & $\mathrm{F}$ & $\mathrm{M}$ & $\mathrm{F}$ & M & $\mathrm{F}$ \\
\hline $\mathrm{N}$ & $50 \quad 50$ & 15 & 15 & 15 & 15 & 50 & 100 & 15 & 30 & 15 & 30 & 50 & 150 & 14 & 45 & 15 & 45 \\
\hline$\hat{x}$ & 92.25 & 23. & & & & 123 & .00 & 31. & & 29. & & 1.38 & .38 & 35. & & 32 & \\
\hline$\hat{\Lambda}_{i}(\%)$ & 92.25 & 79. & & 72 & & 82. & 00 & 70. & & 64. & 79 & 69. & 19 & 59 & 33 & 54 & 67 \\
\hline
\end{tabular}

Nas atividades de coleta de sementes de plantas alógamas, o conhecimento do tamanho efetivo é tão importante, não sendo suficiente coletar centenas ou milhares de sementes de apenas uma única planta, porque elas não valerão mais do que quatro sementes colhidas de quatro plantas diferentes. Por conseguinte, para esta atividade, o conhecimento do $\hat{N}$ é fundamental para delinear as estratégias ótimas de coleta ( Vencovsky, 1987).

Vencovsky (1987) sugere, para aumentar o $\hat{N}$, tanto para coleta de sementes como para a preservação de germoplasma, que se processe o controle gamético feminino através da colheita de um número igual de sementes de cada planta. Esta prática resulta em um tamanho efetivo maior, uma vez que todas as plantas contribuirão com número igual de gametas femininos, não havendo risco 
de umas contribuírem com mais ou menos sementes, como ocorre quando essas são tomadas ao acaso. Tal prática reduz o efeito da deriva genética ou, em termos quantitativos, reduz a variância do número de gametas fornecidos pelas plantas genitoras, aumentando o $\hat{N}$ ou, em outros termos, a representatividade genética do material. Nessa técnica de coleta de campo, o tamanho efetivo máximo atingível é de 4M, sendo $\mathrm{M}$ o número de plantas genitoras. Ainda segundo o autor, o que se deve tomar aleatoriamente é o conjunto de plantas genitoras e não suas sementes. Logo, na atividade de coleta de sementes, o ideal é que se procure sempre reunir descendentes, como sementes, de um maior número possível de plantas genitoras e de preferência um número igual, ou aproximadamente igual. de sementes de cada uma. A recuperação de áreas degradadas com sementes coletadas a partir destes princípios dará origem a populações com alto potencial evolutivo, dada a possibilidade de infinitas novas recombinações genotípicas que, por sua vez, aumentarão a adaptabilidade da espécie ao ambiente, a possíveis mudanças ambientais futura e à colonização de novas áreas.

Com relação à conservação in situ, observou-se para $C$. brasiliense que, mesmo com alta endogamia, a espécie apresenta com potencial para esse tipo de conservação. Isso porque obter-se a área mínima viável para conservação in situ a longo prazo seriam necessários 500 indivíduos (com cruzamentos aleatórios, iguais proporções de indivíduos de ambos ao sexos, sem flutuações na populações, sem sobreposição de geração e distribuição aleatória das famílias) e a curto prazo 50 indivíduos, o número mínimo para essa prática (Frankel \& Suolé, 1981). Sendo a relação $\hat{N} / \mathrm{N}$ da população estudada igual a $0,729(\hat{N}=21,87$ tamanho efetivo de adultos e $\mathrm{N}=30$ adultos amostrados), o número médio de plantas por hectare de 230 indivíduos (Schiavini, 1992) e essa multiplicação obtêm- se 167,67 indivíduos diferentes em 1 ha, supõe-se que teoricamente esta espécie poderá ser conservada dentro de uma área de mais ou menos 5 ha ( 838 
indivíduos diferentes que se acasalam), sem que ocorra perda de alelos raros a médio prazo.

Para a conservação de $C$. brasiliense, podemos considerar a estruturação de poucas reservas, mas relativamente grandes. A sugestão de reservas grandes está especialmente relacionada à possibilidade de presença contínua da fauna associada à espécie, pois a manutenção da elevação de heterozigosidade depende da manutenção da fauna como elemento imprescindível na movimentação dos alelos (realização de cruzamentos, fluxo de pólem e dispersão de propágulos), uma vez que a alta densidade da espécie implica numa disponibilidade de grande número de indivíduos em áreas relativamente pequenas. Isto é devido à capacidade de conservar a variabilidade genética dentro da população ao longo do tempo, à intensa regeneração da espécie e ao aumento da diversidade genética nas plântulas.

Tal resultado decorre da alta densidade de indivíduos na população e mostra que, para o caso da conservação de ecossistemas florestais, o ideal é que a estimativa da área mínima viável seja realizada a partir das espécies raras (menos que 4 indivíduos por hectare), visto que estas requerem muito mais indivíduos para sua manutenção (Hamrick \& Murawski, 1991). Utilizando-se espécies raras na determinação da área mínima viável para a conservação, um grande número de espécies comuns, como $C$. brasiliense, serão preservadas indiretamente, visto que estas requerem menos área para sua manutenção. 


\section{CONCLUSÕES}

O estudo genético da população de $C$. brasiliense permitiu as seguintes conclusões:

- Detectou-se diferenças significativas nas freqüências alélicas e genotípicas entre os diferentes grupos amostrados, entretanto os dados não permitem concluir com precisão se os desvios são devido ao sistema reprodutivo ou devido a fatores evolutivos.

- O teste de aderência ao equilíbrio de Hardy-Weinberg não evidenciou diferenças entre os padrões encontrados dos esperados nos 3 grupos.

- A diversidade genética encontrada dentro dos três gnupos de indivíduos $C$. brasiliense está em torno da média das populações de espécies arbóreas já estudadas. A maior parte da variabilidade genética se encontra dentro das plântulas. Os valores obtidos de heterozigosidade observada para esta espécie, em geral, foram menores que aqueles já encontrados para espécies comuns.

- A análise dos níveis de fixação alélica mostraram a presença de endogamia em todos os grupos, sendo menos pronunciada nas plântulas. A comparação dessas estimativas entre plântulas, jovens e adultos indicam que a espécie pode ter colonizado a área recentemente, ou então os indivíduos adultos homozigotos estão mais adaptados ao estabelecimento em áreas alagadas. Desta forma estaria ocorrendo seleção contra heterozigotos. 
- A análise do tamanho efetivo revelou que quanto maior é o índice de fixação e a diferença na proporção entre sexos, menor é a representatividade genética nos grupos.

- Os resultados gerais indicam que na área de estudo existe a capacidade de conservar a variabilidade genética dentro da população ao longo do tempo, já que a espécie apresenta intensa regeneração, com alta diversidade genética. 


\section{REFERÊNCIAS BIBLIOGRÁFICAS}

ACIESP (ACADEMIA DE CIÊNCIAS DO ESTADO DE SÃO PAULO). Glossário de ecologia. São Paulo. 1987. 271p.

AGREN, J. \& ZACKRISSON, O. Age and size struture of Pinus sylvestris populations on mires in central northern Sweden. Journal of Ecology, v.78, p.1049-1062, 1990.

AIDAR, M. P. M. Ecologia do aribá (Centrolobium tomentosum Guill. Ex Benth.- Fabaceae) e o ecótono mata ciliar da bacia do rio Jacaré Pepira, Campinas, 1992. Dissertação (M.S.) - Ecologia, UNICAMP.

ALBUQUERQUE, J.M. Identificação e germinação de sementes amazônicas. FCAP. Serviço do Documento e informação. 1993. p.54-55.

ALFENAS, S.A.; PETER, I.P.; BRUNE, W.\& PASSADOR, G.C. Eletroforese de proteínas e fungos em essências florestais. UFV, Viçosa- MG. 1991. 242 .

ALVAREZ-BUYLlA, E. \& GARAY, A.A. Population genetic struture of Cecropia obtusifolia, a tropical pionner tree species. Evolution, v.48, n.2, p.437-453, 1994. 
BAWA, K.S. \& O’MALLEY. D.M. Estudios genéticos y de sistemas de cruzamiernto en algunas arbóreas de bosques tropicales. Rev. biol. trop., v.35, n.1, p. 177-188, 1987.

BARROSO, G.M. Sistemática de angiospermas do Brasil. Vol. 1. Editora LTC/Edusp. 1978.

BUCKLEY, D.P.: O.MALLEY, D.M.; APSIT, V.; PRANCE, G.T.; BAWA, K.S. Genetics of Brazil nut (Bertholletia excelsa Humb. \& Bonpl. Lecythidaceae). 1. Genetic variation in natural populations. Their. Appl. Genet., v.76, p. 923-928, 1988.

CARVALHO, P. E. R. Espécies florestais brasileiras recomendadas silviculturais, potencialidades e uso da madeira. CNPFlorestas. EMBRAPA. Brasília. 1994. 124p.

CLAYTON, J. \& TRETIAK, D. Amine- citrate buffers for $\mathrm{pH}$ control in starch gel electrophoresis .Journal of Fisheries Reserch Board of Canada, v. 29, p. 1169-1172, 1972.

CONNELL, J.H. On thr of natural enemies in preventing competitive exclusion in some marine animals and in rain forest trees. In: DEN BOER, P. J. \& GRADWELL, G.R. (Ed.) Dynamics of numbers in populations. Center for Agricultiral publication and Documentation, Wageningen, Netherlans. 1971. 298-312p. 
CROW, J.F. \& KIMURA, M. A. An Introdution to Population Genetics Theory. HARPER \& ROW, PUBLISHERS. 1970. 591 p.

DAUBENMIRE, R. Phenology and other characteristics of tropical semideciduos forest in north-westen Costa Rica. Journal of Ecology, v.60, n.1, p. $147-170,1972$.

DIAS, L.A. dos S. \& KAGEYAMA, P.Y. Variação genética em espécies arbóreas e consequiências para o melhoramento florestal. Agrotrópica, v.3, n.3, p.119-127.1991.

EGUIART, L.E.; PEREZ-NASSER, N.; PINERO, D. Genetic struture, outcrossing rate and heterosis in Astrocaryum mexicanum (tropical palm): implications for evolution and conservation. Heredity, v.69, p.217-228, 1992.

FISCHER, E. A . 1990. Distribuição de frequência de classes de tamanho e estratégia reprodutiva de Calophyllum brasiliense Camb. (GUTTIFERAE) em mata ciliar na Estação Ecológica Estadual Juréia- Itatins, São Paulo. In: Anais do II Simpósio de Ecossistemas da Costa Sul e Sudeste brasileira. Vol II. pp. 337-347.

FRANKEL, O. H. \& SOULÉ, M.S. Conservation and Evolution. Cambridge University Press. Cambridge. 1981. 327 p.

FUTUYMA, D.J. Biologia Evolutiva. Ribeirão Preto, Sociedade Brasileira de Genética. 1992. 621 p. 
GANDARA, F. B. Diversidade genética, taxa de cruzamento e estrutura espacial dos genótipos em uma população de Cedrela fissilis Vell. (Meliaceae). Campinas, 1996. Dissertação (M.S.) - UNICAMP.

GOMES, F.P. Curso de estatística experimental. Piracicaba, USP/ESALQ. $13^{\circ}$ ed. 1990.354 p.

HAMRICK, J. L. \& GODT, M.J.W. Allozyme diversity in plant species. In: Brown, AHD; Clegg, M. T.; Kahler, A L. e Weir, B. S. (Ed.) Plant population genetic resourcer. Genetic Resources. Sinauer. Sunderland. Massachusetts. 1990. p.43- 63.

HAMRICK, J. L.; LINHART, Y. B. \& MITTON. Levels of genetic variation in trees: Influense of Life history characteristcs. In: MT CONKLE (tech coord.) Pranc. Symp. On Isoenzimes of North american Forest Insects. USDA For Service,Gen. Tech Report PSW-48. Barkley. 1979. p 35-41.

HAMRICK, J.L. \& LOVELESS, M.D. Isozyme variation in tropical trees: procedures and preliminary results. Biotropica, v.18, p.201-207, 1986.

HAMRICK, J.L. \& LOVELESS, M.D. The genetic structure of tropical tree populations: association with reproductive biology. In: BOCK, J.H. \& LINHART, Y.B. (Ed.) The Evolutionary Ecology of Plants. Westview Press, Boulder, CO, USA. 1989. p.129-146.

HAMRICK, J.L. \& MURAWSKI, D.A. Levels of allozyme diversity in populations of uncommon neotropical tree species. Journal of Tropical Ecology, v.7, p.395-399, 1991. 
HAMRICK, J.L. Gene flow and distribution of genetic variation in plant populations. In: Differrentiation patterns in higher plants. Copyright by Academic Press. 1987. p. 53-67.

HAMRICK, J.L. The distribuition of genetic variation whitir and among natural forest population. In: SHONEWALD-COX, C.M.; CHAMBERS, S.M.; MACBIDE, B. \& THOMAS, W.L. (Ed.) Genetic and Conservation. New York, The Benjamin/Cummings Publicashin CO. 1983. p. 335-48.

HAMRICK, J. L. Distribuition of genetic whitin and among natural forest population. In, C.M.; CHAMBERS, S.M.; MACBIDE, B. \&. THOMAS, W.L. (Ed.) Shonewald-cox 1982.

HETT. J. \& LOUCKS, O. L. Age structure models of balsam fir and eastern hemlock. Journal of Ecology, v.64, p.1029-1044, 1976.

HILL ,R.J.; PRANCE, G.T.; MORI, S.A.; STEWARD, W.C.; SHIMABUKURU, D. \& BERNARDI, J. Estudo eletroforético da dinâmica da variação genética entre taxa ribeirinhas ao longo do Rio Solimões, América do Sul. ACTA AMAZONICA, v.8, n.2, p.183-99, 1978.

JANSEN, D. H. Herbivores and the number of tree species in tropical forests. American Naturalist. v.940, n.104, p.501-528, 1970.

JOLY, C. Heterogeneidade ambiental e diversidade de estratégias de adaptavas de espécies arbóreas de mata de galeria. In: X Simpósio anual da ACIESP, 1986. Anais. p.50. 
KAGEYAMA, P.Y. Estudo para implantação de matas de galeria na bacia hidrográfica do Passa Cinco visando a utilização para abastecimento público. Piracicaba. ESALQ/USP. Relatório de Pesquisa. 236p. 1986.

KAGEYAMA, P.Y. 1987. Conservação In Situ de recursos genéticos de plantas. IPEF. Piracicaba.(35): pp. 7-37.

KAGEYAMA, P.Y. ; CASTRO, C.F.A .; \& CARPANEZZI, A.A. Implantação de matas ciliares: Estratégias para auxiliar a sucessão secundária. In: Simpósio Sobre Mata Ciliar, Campinas- SP. 1989. Anais. Fundação Cargill,. p.130-43.

KAGEYAMA, P.Y. Genetic struture of tropical tree species of Brasil. In: BAWA, K.S.; HADLEY, M. (Ed.) Reproductive Ecology of Tropical Forest Plants. (Man and the Biosphere, 7). UNESCO and Partheno Publishingg. 1990. p.3383-394.

KAWAGUICI, C.B. Germinação de sementes, estrutura e sobrevivência de uma população de Calophyllum brasiliense Camb. (CLUSIACEAE) em mata de galeria da Estação Ecológica do Panga. Uberlândia, 1994. Monografia de Graduação - Curso de Ciências Biológicas. Universidade Federal de Uberlândia.

KIMURA, M. The neutral theory as a basis for understanding the mechanism of evolution and variation at the molecular level. In: KIMURA, M. ed Molecular Evolution, Protein Polymorphism and the Neutral Theory. Cap. 1. Tokyo and Berlin, Japan Scientific Societies and Springer-Verlag, p. 3-56. 1982. 
KNOWLES, P. \& GRANT, M. Age and size struture analyses of engelmann spruce, ponderosa pine, and limber pine in Colorado. Ecology, v. 64, n.1. p. 1-9, 1983.

LEITE, A. M. C.; RANKIN, J. M. \& LLERAS, E. Ecologia de plântulas de Pithecolobium racemosum Ducke. 2 - O comportamento populacional de plântulas. Acta a mazônica, v.12, n.3, p.529-548, 1982.

LEITE, A. M. C. \& SALOMÃO, A. N. Estrutura populacional de regenerantes de copaîna (Copaifera langsdorfii Desf.) em mata ciliar do Distrito Federal. Acta botânica brasileira, v.6, n. 1, p.123-134, 1992.

LEPSCH-CUNHA, N. Estrutura genética e fenologia de espécies raras de Couratari spp. (Lecythidaceae) na Amazônia Central. Piracicaba, 1996. Dissertação (M.S.) - Escola Superior de Agricultura "Luiz de Queiroz", Universidade de São Paulo.

LEWIS,P.O. \& ZAYKIN, D. Genetic data analysis: Computer program for the analysis of allelic date. Version 1.0 (d12), 1999.

LIEBERG, S. A. Tolerância à inundação e aspectos demográficos de Inga affins D. C. Campinas, 1990. Dissertação (M.S.) - Ecologa, UNICAMP.

LIENGSIRI, C.; YEH, F.C. \& BOYLE, T. J.B. Isozyme analysis of a forest tree, Pterocarpus macrocarpus Kurz. in Thailand. In: Forest Ecology and Managment, v.74, p.13-22, 1995. 
LIMA, W. P. Função hidrológica da mata ciliar. IN: Simpósio sobre mata ciliar, 1989. Anais, L. M. BARBOSA ed. Fundação Cargil. p. 25-42.

LOBO, P.C. Tolerância à inundação de plantas de Talauma ovata ST.Hill. e aspectos do seu comportamento em uma mata ciliar da bacia do Rio Jacaré- Pepira, Brotas, SP. Campinas, 1993. Dissertação (M.S.) - Biologia Vegetal, UNICAMP.

LORENZI, H. Árvores brasileiras. Editora Plantarum LTDA. Nova Odessa, SP. 1992.116p.

LOVELESS, M. D,. \& HAMRICK, J.L. Distribuicion de la variacion en espécies de arbolés tropicales. Revista Biologia Tropicales, v.35, p.165-75. 1987. Suplemento, 1 .

MALTEZ, H. M. Estrutura genética de Aspidosperma polyneuron Muell. Arg. Apocynaceae (Peroba rosa) em uma floresta estacional semidecídua no Estado de São Paulo. Campinas, 1997. 132p. Dissertação (M.S.) - Instituto de Biologia, UNICAMP.

MANTOVANI, W. Conceituação e fatores condicionantes. In: Simpósio sobre mata ciliar, Campinas, SP, 1989. Anais. BARBOSA, L. M. (Ed.) Fundação Cargill. Campinas, SP, 1989. p.120-129.

MANTOVANI, W.; ROSSI, L.; ROMANIUC NETO, S. ASSAD-LUDWIS, I. Y.; WANDERLEY, M. G.; MELO,M. M. R. S \& TOLEDO, C. B. Estudos Fitossociológicos de área de mata ciliar em Mogi- Guaçu, SP, Brasil. In: 
Simpósio sobre mata ciliar, 1989. Anais. L. M. BARBOSA (Ed) Fundação Cargil. p.235-267.

MARCON, G. Estrutura genética de populações de Stylosantes humilis H. B. K. (Leguminosae) de três regiões ecogeográficas do estado do Pernambuco. Piracicaba, 1988. 179p. Tese (Doutorado) - Escola Superior de Agricultura "Luiz de Queiroz", Universidade de São Paulo.

MARQUES, M.C.M. Estudos auto-ecológicos do guanandi (Calophyllum brasiliense Camb. CLUSIACEAE) em mata ciliar no município de Brotas, SP. Campinas, 1994. Dissertação (M.S.) - Biologia vegetal, UNICAMP.

MARTINS, F.R. Estrutura de uma floresta mesófila. Campinas: Editora da UNICAMP. 1991.246p.

MORAES, M. L. T. Variabilidade genética por isoenzimas e caracteres quantitativos em duas populações naturais de Myracroduon urundeuva $\mathrm{F}$. F. \& M. F. Allemão- ANARCADIACEAE (syn: Astronium urundeuva FR Allemão Englre). Piracicaba, 1993. 153p. Tese (Doutorado) - Escola Superior de Agricultura “Luiz de Queiroz", Universidade de São Paulo.

MOREIRA, A.G. Aspectos demográficos de Emmotum nitens (Benth.) Miers (Icacinaceae) em um cerradão distrófico no Distrito Federal. Campinas, 1987. Dissertação (M.S.) - Biologia Vegetal, UNICAMP.

MURAWSKI, D.A. \& BAWA, K.S. Genetic structure and mating system of Stemonoporus oblongifolius (Dipterocarpaceae) in Sri Lanka. Americam Journal of botany, v.81, n.2, p.155-160, 1994. 
MURAWSKI, D. A. Reproductive biology and genetics of tropical trees from a canopy perspective. In: Lawman, M.D. \& Nadkarmi, N.M. Forest Canopies. Academic Press. 1995. p. 457-493.

MURAWSKI, D.A. \& HAMRICK, J.L. The effect of density of flowering individuals on the mating systems of nine tropical tree species. Heredity, v.67, p.167-174, 1991.

MURAWSKI, D. A.; DAYANANDAN, B.; BAWA, K.S. Outocrossing rates of two endemic Shorea species fron Sri Lankan tropical rain forests. Biotropica, v.26, p.23-29, 1994.

NEI, M. F- Statistic and analisis of gene diversity in subdividid populations. Ann. humman genetics, v.41, p.225-33, 1971.

NEI, M. Molecular population genetics and evolution . In: NEUBERGER, A. \& TATUM, E.L., (Ed.) Frontiers of Biology. Elsevier, New York. 1975. V. 40.

NILSSON, C. Conservation management of riparian communities. In: HANSSON, L. (Ed.) Ecological principles of nature conservation. Elsevier applied Science. London. 1992.

NILSSON, C.; GRELSSON, G.; JOHANSSON, M. \& SPERENS, U. Can raity and diversity be predicted in vegetation along river banks? Biological conservation, v.44, p.201-212, 1988. 
OliveIRA, P. E. A.; RIBEIRO, J. F. \& GONZALES, M. I. Estrutura e distribuição espacial de uma população de Kielmeyera coriaceae Mart. de cerrados de Brasília . Revista Brasileira de Botânica, v.12, p.39-47. 1989.

O`MALLEY, D. M. \& BAWA, K. A. Matyng system of a tropical rain forest tree species. Americam Journal of Botany, v.74, n.8, p.1143-49, 1987.

PÉREZ-NASSER, N.; EQUIARTE, L.E. \& PIÑERO, D. Mating system and genetic struture of the distylous tropical tree Psychotria Faxlucens (RUBIACEA). Americam Journal of Botany, v.80, n.1, p.45-52, 1993.

PIO CORREA, M. Dicionário das plantas úteis no brasil e das exóticas cultivadas. Vol. III. Ministério da Agricultura, IBDF. Rio de Janeiro. 1931. p.534-536.

RAMIREZ. N. \& ARROYO, M.K. Estructura poblacional de Copaifera publifora Benth. (Leguminosae; Caesalpinioideae) en los altos Ilanos centrales de Venezuela. Biotropica, v.22, n.2, p.124-132, 1990.

REIS, M.S. Distribuição e dinâmica da variabilidade genética em populações naturais de palmiteiro (Euterpe edulis MARTIUS). Piracicaba, 1996. Tese (Doutorado) - Escola Superior de Agricultura "Luiz de Queiroz", Universidade de São Paulo.

REITZ, R.; KLEIN, R. M. \& REIS, A. Projeto madeira de Santa Catarina. Sellowia. p. 320, 1978. 
RESENDE, J.C.F. Ecologia de população de Copaifera langsdorffii em mata de galeria na Estação Ecológica do Panga (Uberlândia, MG). Brasília, 1997. 60p. Dissertação (M.S.) - Ecologia, Universidade de Brasília.

RESENDE, J.C.F. Estrutura, crescimento e sobrevivência de uma população de Copailera langsdorffi Desf. (Caesalpiniaceae) em mata de galeria no Triângulo Mineiro. Uberlândia, 1994. Monografia (Graduação) - Ciências Biológicas, Universidade Federal de Uberlândia.

RIBEIRO , J.F. \& SCHIA VINI. I. Recuperação de matas de galeria: integração entre a oferta ambiental e a biologia das espécies. In: Ribeiro, J.F. (Ed) Cerrado: Matas de Galeria.. Planaltina: EMBRAPA-CPAC, 1998. 164p.

RODRIGUES, R.R. Análise estrutural das formações ripárias. In: Simpósio Sobre Mata Ciliar, 1989. Anais. B. BARBOSA, L. M. ed. Fundação Cargil. p.99119.

RODRIGUES, R. R. Análise de um remanescente de vegetação natural às margens do rio Passa Cinco, Ipeúma, SP. Campinas, 1992. Tese (Doutorado) - Biologia vegetal, UNICAMP.

SANTOS, E.M.G. Ecologia da polinização, fluxo de pólem e taxa de cruzamento em Bauhinia forficata Link. (Caesalpiniaceae). Piracicaba, 1994. 114p. Dissertação (M.S.) - Escola Superior de Agricultura "Luiz de Queiroz",Universidade de São Paulo. 
SCHIAVINI, I. Estrutura das Comunidades de mata de galeria da Estação Ecológica do Panga (Uberlândia-MG). Campinas, 1992. Tese (Doutorado)Ecologia, UNICAMP.

SCHIAVINI, I. \& ARAUJO, G.M. Considerações sobre a vegetação da Reserva Ecológica do Panga (Uberlândia-MG). Sociedade e Natureza, v.l, p. 6166, 1989.

SCHVARTSMAN, S. Plantas venenosas. Editora Sarvier. São Paulo, SP. 1979. $150 \mathrm{p}$.

SCHNABEL, A.; HAMRICK, J.L. Comparative analisis of population genetic struture in Quercus macrocarpa and $Q$. gambelii (Fagacea). IN: Systematic Botany, v.15, n.2, p.240-251,1990.

SEBBENN, A.M. Estrutura genética de subpopulações de Genipa americana L. (Rubiaceae) a partir de isoenzimas. Piracicaba, 1997. Dissertação (M.S.) Escola Superior de Agricultura "Luiz de Queiroz", Universidade de São Paulo.

SILVA, D.M. Estrutura de tamanho e padrão espacial de uma população de Euterpe edulis Mart. (Arecaceae) em mata mesófila semidecídua no município de Campinas, SP. Campinas, 1991. Dissertação (M.S.) Biologia Vegetal, UNICAMP.

SILVERTON, J.W. Introduction to plant population ecology. Longman ed. London. 1987. 229p. 
SLATKIN, M. Gene flow and genetic drift in a species subject to frequent local extinctions. Theoret. Popul. Biol., v. 12, p.253-62, 1977.

SOLBRIG, O. T. Studies on the population biology of the genus Viola. II. The effect of plant size on fitness in Viola sororia. Evolution, v.35, n.6, p.1080-1093, 1981.

SOLTIS, D.E.; HAUFLER, C.H.; DARROW, D.C. \& GASTONY, G.L. Start gel electrphoresis of ferns: a compilation of grinding buffers, gel and electrode buffers, and staining schedules.American Fern Journal. v.73, n.1. p.9-26. 1983.

STUBER, C.W.; WENDEL, J.F.; GOODMAN, M.M. \& SMITH, J.S.C. Techniques and scoring procedures for starch gel electrophoreses of enzymes from maize (Zea mays L.). Technical Bulletin 286, North Caroline State University, Raleigh, North Caroline. 1988. .87p.

SWOFFORD, D. L. \& SELANDER. Byosys-2. A Computer program for the analysis of allelic variation in population genetics and biochemical systematics. University of Illinois at Urbara-Chanpaign Urbara, Illinois 60801, USA.1997.

TROPPMAR, H. \& MACHADO, M.L.A. Variação da estrutura da mata de galeria na bacia do rio Corumbataí (SP), em relação à água do solo, do tipo de margem e do traçado do rio. Biogeografia, v.8, p.1-28, 1974.

VENCOVSKY, R. Variance of an estimate of outcrossing rate. Revista Brasileira de Genética, v.17, n.3, p.349-51, 1994. 
VENCOVSKY, R. Análise de variância de frequiências alélicas. In: Congresso Latino Americano de Genética, $10^{\circ}$, Rio de Janeiro, Proceedings, Revista Brasileira de Genética, v.15, p.53-60, 1992. (suplemento 1).

VENCOVSKY, R. Tamanho efetivo populacional na coleta e preservação de germoplasmas de espécies alógamas. IPEF, Piracicaba, v.35, 1987.

WEBB, L.J.; TRACEY, J.G. \& WILLIANS, W.T. Regeneration and patern in the subtropical rain forest. Journal of Ecology. v.60, p.675-695, 1972.

WEINER, J. Size hierarchies in experimental populations of annual plants. Ecology, v.66, n.3, p.743-752, 1985.

WEIR, B.S. Genetic data analysis. Methods for discrete population genetc data. North Caraline State University, Sinauer Associates Inc. Pub., Suderland, Massachusetts. 1990.377p.

WEIR, B. S. Genetic data analysis II Ed. Sinauer, Massachusetts. 2 nd ed. 1996. 445p.

WEIR, B.S. \& COCKERHAM, C.C. Estimating F-statistics for the analysis of population structure. Evolution, v.38, n.6, p.1358-1370, 1984.

WENDEL, J. F. e WEEDEN, N. F. Visualization and interpretation of plant isozymes. In: SOLTIS, D.F. e SOLTIS, P.S. (Ed.). Isozymes in plant biology. Portland, Dioscorides Press. 1989. p.5-45. 
WORKMAN, P. \& NISWANDER, J.L. Population studies on southwestern indian tribes. II. Local Genetic differentiation in the Papago. Americam journal human genetic, p.2224-49, 1970.

WRIGHT, S. The interpretation of population struture by F- statistics with special regard to systems of mating. Evolution, v.19, p.395-420, 1965. 


\section{$\underline{\text { ANEXOS }}$}

1- Relação das medidas dos indivíduos de Calophyllum brasiliense Camb. marcados na Estação Ecológica do Panga, Uberlândia - MG. Piracicaba, ESALQ/USP, 1999.

ADULTOS (A): *Indivíduos que apresentam troncos de árvores bifurcados

\begin{tabular}{|l|l|l|}
\hline NÚMERO & CAP $(\mathrm{cm})$ & ALTURA $(\mathrm{m})$ \\
\hline A1 & 116 & 12 \\
\hline A2 & 22 & 8 \\
\hline A3 & 72 & 12 \\
\hline A4 & 33 & 10 \\
\hline A5 & $28+16^{*}$ & 8 \\
\hline A6 & $59+42^{*}$ & 14 \\
\hline A7 & 24 & 8 \\
\hline A8 & 46 & 9 \\
\hline A9 & 19 & 7 \\
\hline A10 & 91 & 10 \\
\hline A11 & 50 & 9 \\
\hline A12 & 81.5 & 9 \\
\hline A13 & 55 & 8 \\
\hline A14 & 103,5 & 16 \\
\hline A15 & 33 & 8 \\
\hline A16 & 39 & 9 \\
\hline A17 & 113 & 14 \\
\hline A18 & $81+29+19 *$ & 13 \\
\hline A19 & 67 & 12 \\
\hline A20 & 53 & 11 \\
\hline A21 & 37 & 9 \\
\hline A22 & 36 & 10 \\
\hline A23 & 53 & 10 \\
\hline A24 & 57 & 9 \\
\hline A25 & 93 & 15 \\
\hline A26 & 56 & 10 \\
\hline A27 & 43 & 11 \\
\hline A28 & 36 & 10 \\
\hline A29 & 59 & 12 \\
\hline A30 & 50 & 12 \\
\hline & & \\
\hline
\end{tabular}


JOVENS (J):

\begin{tabular}{|l|l|l|}
\hline NÚMERO & $\begin{array}{l}\text { CAP } \\
(\mathrm{cm})\end{array}$ & $\begin{array}{l}\text { ALTURA } \\
(\mathrm{m})\end{array}$ \\
\hline $\mathrm{J} 1$ & 11 & 2.5 \\
\hline $\mathrm{J} 2$ & 7.5 & 2,7 \\
\hline $\mathrm{J} 3$ & 7.5 & 3 \\
\hline $\mathrm{J} 4$ & 13 & 4.4 \\
\hline $\mathrm{J} 5$ & 14 & 1,8 \\
\hline $\mathrm{J} 6$ & 12 & 3 \\
\hline $\mathrm{J} 7$ & 7.7 & 3 \\
\hline $\mathrm{J} 8$ & 13 & 5.5 \\
\hline $\mathrm{J} 9$ & 10 & 2.5 \\
\hline $\mathrm{J} 10$ & 14.3 & 6 \\
\hline $\mathrm{J} 11$ & 11.3 & 5.5 \\
\hline $\mathrm{J} 12$ & 10 & 4.5 \\
\hline $\mathrm{J} 13$ & 7.5 & 4 \\
\hline $\mathrm{J} 14$ & 10 & 5 \\
\hline $\mathrm{J} 15$ & 9.5 & 5 \\
\hline $\mathrm{J} 16$ & 9.8 & 4,8 \\
\hline $\mathrm{J} 17$ & 13 & 6 \\
\hline $\mathrm{J} 18$ & 7.9 & 3,2 \\
\hline $\mathrm{J} 19$ & 7.2 & 2.3 \\
\hline $\mathrm{J} 20$ & 12,5 & 7 \\
\hline $\mathrm{J} 21$ & 8,5 & 4.4 \\
\hline $\mathrm{J} 22$ & 12 & 3 \\
\hline $\mathrm{J} 23$ & 11 & 3 \\
\hline $\mathrm{J} 24$ & 10 & 2.5 \\
\hline $\mathrm{J} 25$ & 9.5 & 2.5 \\
\hline $\mathrm{J} 26$ & 10 & 3 \\
\hline $\mathrm{J} 27$ & 13,5 & 3.5 \\
\hline $\mathrm{J} 28$ & 7 & 2 \\
\hline $\mathrm{J} 29$ & 9.5 & 2 \\
\hline $\mathrm{J} 30$ & 12.5 & 3 \\
\hline & & \\
\hline
\end{tabular}




\section{PLÂNTULAS (P):}

\begin{tabular}{|l|l|l|}
\hline NÚMERO & $\begin{array}{l}\text { DlÂMETRO } \\
(\mathrm{mm})\end{array}$ & $\begin{array}{l}\text { ALTURA } \\
(\mathrm{cm})\end{array}$ \\
\hline P1 & 6 & 18 \\
\hline P2 & 5 & 15 \\
\hline P3 & 5 & 14 \\
\hline P4 & 5 & 25 \\
\hline P5 & 6 & 27 \\
\hline P6 & 4 & 15 \\
\hline P7 & 5 & 25 \\
\hline P8 & 4 & 22 \\
\hline P9 & 6 & 27 \\
\hline P10 & 6 & 18 \\
\hline P11 & 6 & 30 \\
\hline P12 & 5 & 28 \\
\hline P13 & 6 & 30 \\
\hline P14 & 6 & 25 \\
\hline P15 & 6 & 27 \\
\hline P16 & 5 & 22 \\
\hline P17 & 6 & 27 \\
\hline P18 & 5 & 30 \\
\hline P19 & 5 & 29 \\
\hline P20 & 5 & 28 \\
\hline P21 & 4 & 23 \\
\hline P22 & 6 & 30 \\
\hline P23 & 4 & 23 \\
\hline P24 & 5 & 27 \\
\hline P25 & 5 & 28 \\
\hline P26 & 4 & 23 \\
\hline P27 & 5 & 28 \\
\hline P28 & 5 & 25 \\
\hline P29 & 6 & 30 \\
\hline P30 & 5 & 27 \\
\hline & & \\
\hline
\end{tabular}




\begin{tabular}{|l|r|r|}
\hline Número & $D(\mathrm{~mm})^{\star}$ & $A(\mathrm{~cm})^{\star \star}$ \\
\hline P31 & 6 & 16 \\
\hline P32 & 4 & 23 \\
\hline P33 & 6 & 14 \\
\hline P34 & 6 & 30 \\
\hline P35 & 5 & 16 \\
\hline P36 & 6 & 23 \\
\hline P37 & 4 & 26 \\
\hline P38 & 4 & 27 \\
\hline P39 & 5 & 17 \\
\hline P40 & 5 & 26 \\
\hline P41 & 6 & 24 \\
\hline P42 & 6 & 25 \\
\hline P43 & 6 & 22 \\
\hline P44 & 6 & 25 \\
\hline P45 & 6 & 28 \\
\hline P46 & 6 & 29 \\
\hline P47 & 5 & 23 \\
\hline P48 & 5 & 24 \\
\hline P49 & 6 & 23 \\
\hline P50 & 6 & 18 \\
\hline P51 & 6 & 24 \\
\hline P52 & 5 & 25 \\
\hline P53 & 6 & 30 \\
\hline P54 & 6 & 19 \\
\hline P55 & 6 & 20 \\
\hline P56 & 4 & 23 \\
\hline P57 & 3 & 25 \\
\hline P58 & 4 & 26 \\
\hline P59 & 5 & 24 \\
\hline P60 & 5 & 24 \\
\hline P61 & 5 & 26 \\
\hline P62 & 5 & 28 \\
\hline P63 & 5 & $26 \mid$ \\
\hline P64 & 5 & 24 \\
\hline P65 & 6 & 25 \\
\hline & & \\
\hline
\end{tabular}

\begin{tabular}{|l|r|r|}
\hline Número & D $(\mathrm{mm}){ }^{*}$ & A $(\mathrm{cm})^{* *}$ \\
\hline P66 & 6 & 25 \\
\hline P67 & 6 & 27 \\
\hline P68 & 6 & 27 \\
\hline P69 & 5 & 30 \\
\hline P70 & 6 & 29 \\
\hline P71 & 6 & 26 \\
\hline P72 & 6 & 26 \\
\hline P73 & 6 & 25 \\
\hline P74 & 5 & 27 \\
\hline P75 & 6 & 26 \\
\hline P76 & 6 & 18 \\
\hline P77 & 6 & 18 \\
\hline P78 & 6 & 23 \\
\hline P79 & 6 & 27 \\
\hline P80 & 4 & 26 \\
\hline P81 & 6 & 30 \\
\hline P82 & 5 & 28 \\
\hline P83 & 5 & 28 \\
\hline P84 & 5 & 24 \\
\hline P85 & 6 & 24 \\
\hline P86 & 6 & 25 \\
\hline P87 & 6 & 25 \\
\hline P88 & 6 & 14 \\
\hline P89 & 5 & 19 \\
\hline P90 & 6 & 26 \\
\hline P91 & 6 & 24 \\
\hline P92 & 5 & 27 \\
\hline P93 & 6 & 29 \\
\hline P94 & 5 & 29 \\
\hline P95 & 6 & 28 \\
\hline P96 & 6 & 25 \\
\hline P97 & 6 & 24 \\
\hline P98 & 6 & 26 \\
\hline P99 & 5 & 24 \\
\hline P100 & 6 & 28 \\
\hline & & \\
\hline
\end{tabular}

* DIÂMETRO; ** ALTURA 
2- Protocolo para enzimas de Calophyllum brasiliense Camb. Piracicaba, ESALQ/USP, 1999.

6PGDH

.Ácido 6-fosfoglucônico, Na3

$20 \mathrm{mg}$

.NADP

$1 \mathrm{ml}$

.MTT

$1 \mathrm{ml}$

.PMS

$1 \mathrm{ml}$

. $\mathrm{MgCl} 2(1 \%)$

$1 \mathrm{ml}$

.Tris $\mathrm{Hcl} \quad 0,1 \mathrm{M}, \mathrm{pH} 8,0$

$50 \mathrm{ml}$

Inocular no escuro, por 15-30 minutos a 30-37 graus

\section{MDH}

Ácido Málico

DL - Ácido málico

$10 \mathrm{~g}$

.Água destilada

$80 \mathrm{ml}$

Ajustar o pH 8,0 com NaOH 1M, completar o vol. com $100 \mathrm{ml}$

Coloração: Inocular o gel no escuro, por 15-60 min.

Ácido Málico 0,5M pH 8,0 $4 \mathrm{ml}$

NAD

$1 \mathrm{ml}$

.MTT

$1 \mathrm{ml}$

.PMS

$1 \mathrm{ml}$

.Tris $\mathrm{Hcl} 0,1 \mathrm{M}$ pH 8,5

$50 \mathrm{ml}$

PO

.O. Dianisidina $30 \mathrm{mg}$

Etanol $25 \mathrm{ml}$

.Tampão acetato de sódio pH 5,0 (0,2M) $25 \mathrm{ml}$ 
.Agitar o Etanol e a Dianisidina e adicionar o tampão

.Inocular por 30 min. em estufa a 37 graus

.Adicionar $1,5 \mathrm{ml}$ de $\mathrm{H}_{2} \mathrm{O}_{2}(30 \%)\left(0,5 \mathrm{ml} \mathrm{H}_{2} \mathrm{O}_{2}+1 \mathrm{ml} \mathrm{H}_{2} \mathrm{O}\right)$

\section{SKDH}

.Ácido Xiquímico

$50 \mathrm{mg}$

.NADP

$1 \mathrm{ml}$

.MTT

$\mathrm{l} \mathrm{ml}$

. $\mathrm{PMS}$

$1 \mathrm{ml}$

.Tris $\mathrm{Hcl} 0,1 \mathrm{M} \mathrm{pH} 8,5$

$50 \mathrm{ml}$

Inocular o gel no escuro, durante 30 a $60 \mathrm{~min}$.

\section{PGI}

.Frutose-6-fosfato

$37,5 \mathrm{mg}$

.NADP

$1 \mathrm{ml}$

MTT

$1 \mathrm{ml}$

.PMS

$1 \mathrm{ml}$

. $\mathrm{MgCl} 2(1 \%)$

$1 \mathrm{ml}$

.Glucose-6-fosfato desidrogenase (G6PDH)

$0,01 \mathrm{ml}$

.Tris - Hcl 0,1M, pH 8,0

$50 \mathrm{ml}$

Adicionar G6PDH por último, incubar no escuro.

\section{GOT}

Solução A

.Ácido L-aspartico

$75 \mathrm{mg}$

.Ácido alfa-Ketoglutárico 
.Tris $\mathrm{Hcl} 0,2 \mathrm{M}, \mathrm{pH} 8,0$

$50 \mathrm{ml}$

Ajustar o pH para 8,0 com $\mathrm{NaOH}$

*Pode ser preparada em estoque

Solução B

.Solução A

$50 \mathrm{ml}$

.Peridoxal-5-fosfato

$2,5 \mathrm{mg}$

.Fast blue BB

$50 \mathrm{mg}$

.Imergir a solução no gel no escuro e incubar a 30-37 graus até aparecimento das bandas

\section{LAP}

. $\mathrm{L}$ - Leucine

$25 \mathrm{mg}$

.Fast black

$30 \mathrm{mg}$

.Tampão Tris maleato $0,1 \mathrm{M}$ pH 5.4

$20 \mathrm{ml}$

.Água destilada

$50 \mathrm{ml}$

Incubar a 30-37 graus no escuro

\section{ACP}

.Alfa-Naftil Fosfato Ácido Sódio

$50 \mathrm{mg}$

.Fast garnet GBC Salt

$50 \mathrm{mg}$

. $\mathrm{MgCl} 2$

$0,5 \mathrm{ml}$

.Tampão Acetato de Sódio 0,1M pH 5,0

$50 \mathrm{ml}$

Incubar o gel no claro, pode ser observado no dia seguinte 
3- Frequências genotípicas de 14 locos isoenzimáticos nos 3 grupos de ind. de Calophyllum brasiliense Camb. Piracicaba, ESALQ/USP. 1999.

\begin{tabular}{|c|c|c|c|c|c|c|c|c|c|c|c|c|c|c|}
\hline IND & $\mathrm{MDH}$ & $\mathrm{POl}$ & $\mathrm{PO} 2$ & $6 \mathrm{PGD}$ & SKD & PGI & GOI & $\mathrm{GO} 2$ & GO3 & $\mathrm{ACP} I$ & $\mathrm{ACP}$ & $2 \mathrm{ACP}$ & LAPI & LAP2 \\
\hline 1 & 12 & 11 & 11 & 11 & 11 & 22 & 11 & 11 & 11 & 11 & 11 & 11 & 11 & 12 \\
\hline 2 & 3.3 & 11 & 13 & 11 & 22 & 22 & 11 & 11 & 11 & 11 & 11 & 11 & 11 & 12 \\
\hline 3 & 23 & 11 & 13 & 12 & 22 & 22 & 11 & 11 & 11 & 11 & 11 & 11 & 11 & 12 \\
\hline 4 & 23 & 11 & 33 & - & 11 & 22 & 11 & 11 & 11 & 11 & 11 & 11 & 11 & 22 \\
\hline 5 & 33 & 11 & 11 & 12 & 22 & 22 & 11 & 11 & 11 & 11 & 11 & 11 & 11 & 22 \\
\hline 6 & 33 & 11 & 13 & 12 & 22 & 12 & 11 & 11 & 11 & 11 & 11 & 11 & 11 & 11 \\
\hline 7 & 2.3 & 11 & 33 & 11 & 22 & 11 & 11 & 11 & 11 & 11 & 11 & 11 & 11 & 11 \\
\hline 8 & 23 & 11 & 13 & 11 & 22 & 11 & 11 & 11 & 11 & 11 & 11 & 11 & 11 & 11 \\
\hline 9 & 23 & 11 & 11 & 12 & 12 & 11 & 11 & 11 & 11 & 11 & 11 & 11 & 11 & 11 \\
\hline 10 & 33 & 11 & 13 & 12 & 22 & 11 & 11 & 11 & 11 & 11 & 11 & 11 & 11 & 11 \\
\hline 11 & 22 & 11 & 11 & 11 & 22 & 12 & 11 & 11 & 11 & 11 & 11 & 11 & 11 & 11 \\
\hline 12 & 11 & 11 & 33 & 11 & 22 & 11 & 11 & 11 & 11 & 11 & 11 & 11 & 11 & 11 \\
\hline 13 & 11 & 11 & 11 & 11 & 22 & 11 & 11 & 11 & 11 & 11 & 11 & 11 & 11 & 11 \\
\hline 14 & 23 & 11 & 13 & 12 & 12 & 11 & 11 & 11 & 11 & 11 & 11 & 11 & 11 & 12 \\
\hline 15 & 11 & 11 & 13 & 12 & 12 & 11 & 11 & 11 & 11 & 11 & 11 & 11 & 11 & 11 \\
\hline 16 & 12 & 11 & 33 & - & 22 & 11 & 11 & 11 & 11 & 11 & 11 & 11 & 11 & 11 \\
\hline 17 & 33 & 11 & 33 & - & 22 & 11 & 11 & 11 & 11 & 11 & 11 & 11 & 11 & 12 \\
\hline 18 & 13 & 11 & 33 & - & 22 & 22 & 11 & 11 & 11 & 11 & 11 & 11 & 11 & 22 \\
\hline 19 & 12 & 11 & 23 & - & 22 & 22 & 11 & 11 & 11 & 11 & 11 & 11 & 11 & 22 \\
\hline 20 & 1.3 & 11 & 33 & - & 22 & 12 & 11 & 11 & 11 & 11 & 11 & 11 & 11 & 12 \\
\hline 21 & 23 & 11 & 33 & 22 & 22 & 12 & 11 & 11 & 11 & 11 & 11 & 11 & 11 & 12 \\
\hline 22 & 13 & 11 & 11 & 12 & 12 & 22 & 11 & 11 & 11 & 11 & 11 & 11 & 11 & 11 \\
\hline 2.3 & 33 & 11 & 33 & 12 & 22 & 22 & 11 & 11 & 11 & 11 & 11 & 11 & 11 & 22 \\
\hline 24 & 33 & 11 & 11 & 12 & 11 & 22 & 11 & 11 & 11 & 11 & 11 & 11 & 11 & 22 \\
\hline 25 & 23 & 11 & 13 & 12 & 11 & 22 & 11 & 11 & 11 & 11 & 11 & 11 & 11 & 22 \\
\hline 26 & 33 & 11 & 11 & 12 & 12 & 22 & 11 & 11 & 11 & 11 & 11 & 11 & 11 & 22 \\
\hline 27 & 12 & 11 & 12 & 22 & 11 & 11 & 11 & 11 & 11 & 11 & 11 & 11 & 11 & 22 \\
\hline 28 & 23 & 11 & 11 & 22 & 11 & 22 & 11 & 11 & 11 & 11 & 11 & 11 & 11 & 22 \\
\hline 29 & 33 & 11 & 33 & 22 & 11 & 11 & 11 & 11 & 11 & 11 & 11 & 11 & 11 & 12 \\
\hline 30 & 33 & 11 & 33 & 12 & 11 & 11 & 11 & 11 & 11 & 11 & 11 & 11 & 11 & 11 \\
\hline
\end{tabular}

JOVENS:

\begin{tabular}{|c|c|c|c|c|c|c|c|c|c|c|c|c|c|c|}
\hline IND & $\mathrm{MDH}$ & $\mathrm{PO} 1$ & $\mathrm{PO} 2$ & 6PGD & SKD & PGI & $\mathrm{GOl}$ & $\mathrm{GO} 2$ & GO3 & $\mathrm{ACP} 1$ & $\mathrm{ACP} 2$ & $\mathrm{ACP} 3$ & LAPI & LAP2 \\
\hline 1 & 23 & 11 & 11 & 11 & 11 & 12 & 11 & 11 & 11 & 11 & 11 & 11 & 11 & 11 \\
\hline 2 & 23 & 11 & 11 & 11 & 11 & 11 & 11 & 11 & 11 & 11 & 11 & 11 & 11 & 11 \\
\hline 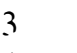 & 12 & 11 & 11 & 12 & 22 & 11 & 11 & 11 & 11 & 11 & 11 & 11 & 11 & 22 \\
\hline 4 & 33 & 11 & 11 & 12 & 22 & 11 & 11 & 11 & 11 & 11 & 11 & 11 & 11 & 12 \\
\hline 5 & 23 & 11 & 11 & 11 & 22 & 12 & 11 & 11 & 11 & 11 & 11 & 11 & 11 & 11 \\
\hline 6 & 33 & 11 & 13 & 11 & 22 & 22 & 11 & 11 & 11 & 11 & 11 & 11 & 11 & 22 \\
\hline
\end{tabular}




$\begin{array}{lllllllllllllll}7 & 13 & 11 & 33 & 11 & 22 & 12 & 11 & 11 & 11 & 11 & 11 & 11 & 11 & 11 \\ 8 & 11 & 11 & 13 & 11 & 22 & 11 & 11 & 11 & 11 & 11 & 11 & 11 & 11 & 11 \\ 9 & 12 & 11 & 11 & 12 & 22 & 11 & 11 & 11 & 11 & 11 & 11 & 11 & 11 & 11 \\ 10 & 12 & 11 & 12 & 11 & 12 & 11 & 11 & 11 & 11 & 11 & 11 & 11 & 11 & 11 \\ 11 & 12 & 11 & 11 & 11 & 22 & 11 & 11 & 11 & 11 & 11 & 11 & 11 & 11 & 11 \\ 12 & 33 & 11 & 33 & 11 & 22 & 11 & 11 & 11 & 11 & 11 & 11 & 11 & 11 & 11 \\ 13 & 23 & 11 & 11 & 11 & 22 & 11 & 11 & 11 & 11 & 11 & 11 & 11 & 11 & 11 \\ 14 & 11 & 11 & 11 & 11 & 11 & 11 & 11 & 11 & 11 & 11 & 11 & 11 & 11 & 11 \\ 15 & 11 & 11 & 11 & 11 & 11 & 11 & 11 & 11 & 11 & 11 & 11 & 11 & 11 & 11 \\ 16 & 13 & 11 & 11 & 11 & 11 & 22 & 11 & 11 & 11 & 11 & 11 & 11 & 11 & 11 \\ 17 & 33 & 11 & 12 & 11 & 22 & 11 & 11 & 11 & 11 & 11 & 11 & 11 & 11 & 11 \\ 18 & 23 & 11 & 11 & 22 & 12 & 22 & 11 & 11 & 11 & 11 & 11 & 11 & 11 & 12 \\ 19 & 12 & 11 & 11 & 12 & 12 & 11 & 11 & 11 & 11 & 11 & 11 & 11 & 11 & 11 \\ 20 & 23 & 11 & 13 & 12 & 12 & 11 & 11 & 11 & 11 & 11 & 11 & 11 & 11 & 11 \\ 21 & 23 & 11 & 13 & 11 & 11 & 11 & 11 & 11 & 11 & 11 & 11 & 11 & 11 & 11 \\ 22 & 23 & 11 & 12 & 11 & 12 & 22 & 11 & 11 & 11 & 11 & 11 & 11 & 11 & 12 \\ 23 & 23 & 11 & 11 & 12 & 12 & 11 & 11 & 11 & 11 & 11 & 11 & 11 & 11 & 11 \\ 24 & 23 & 11 & 13 & 11 & 11 & 22 & 11 & 11 & 11 & 11 & 11 & 11 & 11 & 11 \\ 25 & 12 & 11 & 13 & 12 & 12 & 22 & 11 & 11 & 11 & 11 & 11 & 11 & 11 & 11 \\ 26 & 33 & 11 & 13 & 11 & 22 & 12 & 11 & 11 & 11 & 11 & 11 & 11 & 11 & 12 \\ 27 & 33 & 11 & 11 & 11 & 12 & 22 & 11 & 11 & 11 & 11 & 11 & 11 & 11 & 11 \\ 28 & 23 & 11 & 12 & 12 & 12 & 22 & 11 & 11 & 11 & 11 & 11 & 11 & 11 & 11 \\ 29 & 12 & 11 & 12 & 12 & 11 & 22 & 11 & 11 & 11 & 11 & 11 & 11 & 11 & 11 \\ 30 & 33 & 11 & 11 & 11 & 11 & 22 & 11 & 11 & 11 & 11 & 11 & 11 & 11 & 11\end{array}$

PLÂNTULAS:

\begin{tabular}{|c|c|c|c|c|c|c|c|c|c|c|c|c|c|c|}
\hline IND & $\mathrm{MDH}$ & $\mathrm{POI}$ & $\mathrm{PO} 2$ & 6PGD & SKD & PGI & GOI & $\mathrm{GO} 2$ & GO3 & $\mathrm{ACP} 1$ & ACP2 & ACP3 & L.AP 1 & L.AP2 \\
\hline 1 & 12 & 11 & 11 & 12 & 11 & 12 & 11 & 11 & 11 & 11 & 11 & 11 & 11 & 11 \\
\hline 2 & 23 & 11 & 11 & 12 & - & 11 & 11 & 11 & 11 & 11 & 11 & 11 & 11 & 11 \\
\hline 3 & 23 & 11 & 33 & 12 & 22 & 11 & 11 & 11 & 11 & 11 & 11 & 11 & 11 & 11 \\
\hline 4 & 23 & 11 & 33 & 12 & 11 & 11 & 11 & 11 & 11 & 11 & 11 & 11 & 11 & 11 \\
\hline 5 & 22 & 11 & 11 & 12 & 22 & 11 & 11 & 11 & 11 & 11 & 11 & 11 & 11 & 11 \\
\hline 6 & 12 & 11 & 11 & 12 & 11 & 11 & 11 & 11 & 11 & 11 & 11 & 11 & 11 & 11 \\
\hline 7 & 23 & 11 & 12 & 12 & - & 11 & 11 & 11 & 11 & 11 & 11 & 11 & 11 & 22 \\
\hline 8 & 23 & 11 & 11 & 12 & 11 & 22 & 11 & 11 & 11 & 11 & 11 & 11 & 11 & 11 \\
\hline 9 & 33 & 11 & 22 & 12 & 12 & 11 & 11 & 11 & 11 & 11 & 11 & 11 & 11 & 11 \\
\hline 10 & 33 & 11 & 13 & 11 & 11 & 11 & 11 & 11 & 11 & 11 & 11 & 11 & 11 & 11 \\
\hline 11 & 23 & 11 & 13 & 12 & 22 & 11 & 11 & 11 & 11 & 11 & 11 & 11 & 11 & 11 \\
\hline 12 & 23 & 11 & 13 & 12 & 11 & 22 & 11 & 11 & 11 & 11 & 11 & 11 & 11 & 11 \\
\hline 13 & 23 & 11 & 12 & 12 & 11 & 12 & 11 & 11 & 11 & 11 & 11 & 11 & 11 & 11 \\
\hline 14 & 23 & 11 & 12 & 12 & 11 & 11 & 11 & 11 & 11 & 11 & 11 & 11 & 11 & 11 \\
\hline 15 & 33 & 11 & 13 & 12 & - & 11 & 11 & 11 & 11 & 11 & 11 & 11 & 11 & 11 \\
\hline 16 & 23 & 11 & 11 & 12 & 22 & 11 & 11 & 11 & 11 & 11 & 11 & 11 & 11 & 11 \\
\hline 17 & 33 & 11 & 11 & 12 & - & 11 & 11 & 11 & 11 & 11 & 11 & 11 & 11 & 11 \\
\hline 18 & 33 & 11 & 11 & 12 & 12 & 11 & 11 & 11 & 11 & 11 & 11 & 11 & 11 & 12 \\
\hline 19 & 12 & 11 & 11 & 12 & 22 & 22 & 11 & 11 & 11 & 11 & 11 & 11 & 11 & 12 \\
\hline 20 & 33 & 11 & 22 & 22 & 12 & 22 & 11 & 11 & 11 & 11 & 11 & 11 & 11 & 11 \\
\hline 21 & 13 & 11 & 11 & 12 & 22 & 11 & 11 & 11 & 11. & 11 & 11 & 11 & 11 & 11 \\
\hline 22 & 23 & 11 & 11 & 12 & - & 11 & 11 & 11 & 11 & 11 & 11 & 11 & 11 & 11 \\
\hline 23 & 33 & 11 & 12 & 12 & 22 & 11 & 11 & 11 & 11 & 11 & 11 & 11 & 11 & 11 \\
\hline
\end{tabular}




\begin{tabular}{|c|c|c|c|c|c|c|c|c|c|c|c|c|c|c|}
\hline 24 & 23 & 11 & 23 & - & 22 & 11 & 11 & 11 & 11 & 11 & 11 & 11 & 11 & 11 \\
\hline 25 & 33 & 11 & 11 & 12 & 22 & 11 & 11 & 11 & 11 & 11 & 11 & 11 & 11 & 11 \\
\hline 26 & 3.3 & 11 & 1.3 & 12 & 22 & 11 & 11 & 11 & 11 & 11 & 11 & 11 & 11 & 11 \\
\hline 27 & 23 & 11 & 11 & 12 & 22 & 11 & 11 & 11 & 11 & 11 & 11 & 11 & 11 & 12 \\
\hline 28 & 11 & 11 & 12 & 11 & 12 & 11 & 11 & 11 & 11 & 11 & 11 & 11 & 11 & 11 \\
\hline 29 & 23 & 11 & 12 & 22 & 22 & 11 & 11 & 11 & 11 & 11 & 11 & 11 & 11 & 11 \\
\hline 30 & 23 & 11 & 11 & 12 & 22 & 11 & 11 & 11 & 11 & 11 & 11 & 11 & 11 & 11 \\
\hline 31 & 12 & 11 & 12 & 11 & 12 & 11 & 11 & 11 & 11 & 11 & 11 & 11 & 11 & 11 \\
\hline 32 & 11 & 11 & 11 & 12 & 11 & 11 & 11 & 11 & 11 & 11 & 11 & 11 & 11 & 11 \\
\hline 3.3 & 12 & 11 & 11 & 12 & 11 & 12 & 11 & 11 & 11 & 11 & 11 & 11 & 11 & 11 \\
\hline 34 & 2.3 & 11 & 13 & 12 & 11 & 11 & 11 & 11 & 11 & 11 & 11 & 11 & 11 & 12 \\
\hline 35 & 23 & 11 & 13 & 12 & 11 & 11 & 11 & 11 & 11 & 11 & 11 & 11 & 11 & 22 \\
\hline 36 & 33 & 11 & 33 & 22 & 22 & 11 & 11 & 11 & 11 & 11 & 11 & 11 & 11 & 22 \\
\hline 37 & 33 & 11 & 3.3 & 22 & - & 12 & 11 & 11 & 11 & 11 & 11 & 11 & 11 & 12 \\
\hline 38 & 11 & 11 & 13 & 12 & 11 & 22 & 11 & 11 & 11 & 11 & 11 & 11 & 11 & 11 \\
\hline 39 & 13 & 11 & 11 & 11 & 12 & 11 & 11 & 11 & 11 & 11 & 11 & 11 & 11 & 11 \\
\hline 40 & 22 & 11 & 12 & 11 & 11 & 12 & 11 & 11 & 11 & 11 & 11 & 11 & 11 & 11 \\
\hline 41 & 23 & 11 & 13 & 12 & 12 & 12 & 11 & 11 & 11 & 11 & 11 & 11 & 11 & 12 \\
\hline 42 & 23 & 11 & 1.3 & 11 & 12 & 12 & 11 & 11 & 11 & 11 & 11 & 11 & 11 & 11 \\
\hline 43 & 23 & 11 & 33 & 12 & 11 & 22 & 11 & 11 & 11 & 11 & 11 & 11 & 11 & 11 \\
\hline 44 & 33 & 11 & 33 & 12 & 12 & 22 & 11 & 11 & 11 & 11 & 11 & 11 & 11 & 12 \\
\hline 45 & 33 & 11 & 11 & 11 & 12 & 22 & 11 & 11 & 11 & 11 & 11 & 11 & 11 & 12 \\
\hline 46 & 2.3 & 11 & 13 & 12 & 12 & 11 & 11 & 11 & 11 & 11 & 11 & 11 & 11 & 11 \\
\hline 47 & 23 & 11 & 13 & 12 & 22 & 11 & 11 & 11 & 11 & 11 & 11 & 11 & 11 & 11 \\
\hline 48 & 12 & 11 & 12 & 22 & 22 & 12 & 11 & 11 & 11 & 11 & 11 & 11 & 11 & 11 \\
\hline 49 & 13 & 11 & 22 & 22 & 11 & 11 & 11 & 11 & 11 & 11 & 11 & 11 & 11 & 12 \\
\hline 50 & 11 & 11 & 3.3 & 11 & 12 & 12 & 11 & 11 & 11 & 11 & 11 & 11 & 11 & 11 \\
\hline 51 & 1.3 & 11 & 33 & 11 & 22 & 11 & 11 & 11 & 11 & 11 & 11 & 11 & 11 & 12 \\
\hline 52 & 1.3 & 11 & 13 & 12 & 11 & 11 & 11 & 11 & 11 & 11 & 11 & 11 & 11 & 11 \\
\hline 5.3 & 23 & 11 & 13 & 11 & 12 & 11 & 11 & 11 & 11 & 11 & 11 & 11 & 11 & 12 \\
\hline 54 & 23 & 11 & 13 & 11 & 12 & 12 & 11 & 11 & 11 & 11 & 11 & 11 & 11 & 12 \\
\hline 55 & 23 & 11 & 23 & 12 & 12 & 12 & 11 & 11 & 11 & 11 & 11 & 11 & 11 & 11 \\
\hline 56 & 3.3 & 11 & 11 & 12 & 12 & 12 & 11 & 11 & 11 & 11 & 11 & 11 & 11 & 11 \\
\hline 57 & 33 & 11 & 11 & 12 & 11 & 11 & 11 & 11 & 11 & 11 & 11 & 11 & 11 & 11 \\
\hline 58 & 12 & 11 & 12 & 11 & 11 & 11 & 11 & 11 & 11 & 11 & 11 & 11 & 11 & 12 \\
\hline 59 & 12 & 11 & 13 & 12 & 11 & 12 & 11 & 11 & 11 & 11 & 11 & 11 & 11 & 12 \\
\hline 60 & 1.3 & 11 & 11 & 12 & - & 11 & 11 & 11 & 11 & 11 & 11 & 11 & 11 & 12 \\
\hline 61 & 11 & 11 & 12 & 11 & 12 & 12 & 11 & 11 & 11 & 11 & 11 & 11 & 11 & 11 \\
\hline 62 & 3.3 & 11 & 1.3 & 12 & 22 & 12 & 11 & 11 & 11 & 11 & 11 & 11 & 11 & 12 \\
\hline 6.3 & 23 & 11 & 33 & 22 & 12 & 11 & 11 & 11 & 11 & 11 & 11 & 11 & 11 & 12 \\
\hline 64 & 23 & 11 & 33 & 11 & 12 & 12 & 11 & 11 & 11 & 11 & 11 & 11 & 11 & 11 \\
\hline 65 & 13 & 11 & 23 & 11 & 12 & 11 & 11 & 11 & 11 & 11 & 11 & 11 & 11 & 11 \\
\hline 66 & 13 & 11 & 11 & 12 & 12 & 11 & 11 & 11 & 11 & 11 & 11 & 11 & 11 & 22 \\
\hline 67 & 33 & 11 & 13 & 12 & 12 & 12 & 11 & 11 & 11 & 11 & 11 & 11 & 11 & 11 \\
\hline 68 & 33 & 11 & 11 & 12 & 11 & 12 & 11 & 11 & 11 & 11 & 11 & 11 & 11 & 22 \\
\hline 69 & 11 & 11 & 12 & 11 & 22 & 11 & 11 & 11 & 11 & 11 & 11 & 11 & 11 & 11 \\
\hline 70 & 12 & 11 & 13 & 11 & 22 & 11 & 11 & 11 & 11 & 11 & 11 & 11 & 11 & 11 \\
\hline 71 & 22 & 11 & 22 & 11 & 22 & 12 & 11 & 11 & 11 & 11 & 11 & 11 & 11 & 12 \\
\hline 72 & 23 & 11 & 33 & 12 & 12 & 11 & 11 & 11 & 11 & 11 & 11 & 11 & 11 & 11 \\
\hline 73 & 23 & 11 & 2.3 & 12 & 11 & 12 & 11 & 11 & 11 & 11 & 11 & 11 & 11 & 12 \\
\hline 74 & 22 & 11 & 3.3 & 12 & 22 & 12 & 11 & 11 & 11 & 11 & 11 & 11 & 11 & 11 \\
\hline 75 & 22 & 11 & 13 & 22 & 11 & 22 & 11 & 11 & 11 & 11 & 11 & 11 & 11 & 12 \\
\hline 76 & 33 & 11 & 13 & 12 & 12 & 11 & 11 & 11 & 11 & 11 & 11 & 11 & 11 & 22 \\
\hline 77 & 12 & 11 & 11 & 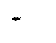 & 12 & 11 & 11 & 11 & 11 & 11 & 11 & 11 & 11 & 11 \\
\hline
\end{tabular}




$\begin{array}{lllllllllllllll}78 & 11 & 11 & 11 & 22 & 12 & 11 & 11 & 11 & 11 & 11 & 11 & 11 & 11 & 11 \\ 79 & 33 & 11 & 13 & 22 & 11 & 11 & 11 & 11 & 11 & 11 & 11 & 11 & 11 & 11 \\ 80 & 23 & 11 & 13 & 12 & 11 & 22 & 11 & 11 & 11 & 11 & 11 & 11 & 11 & 11 \\ 81 & 23 & 11 & 11 & 12 & 12 & 11 & 11 & 11 & 11 & 11 & 11 & 11 & 11 & 11 \\ 82 & 23 & 11 & 12 & 12 & 12 & 11 & 11 & 11 & 11 & 11 & 11 & 11 & 11 & 11 \\ 83 & 23 & 11 & 22 & 11 & 22 & 11 & 11 & 11 & 11 & 11 & 11 & 11 & 11 & 11 \\ 84 & 23 & 11 & 23 & 11 & 22 & 11 & 11 & 11 & 11 & 11 & 11 & 11 & 11 & 11 \\ 85 & 23 & 11 & 23 & 12 & 11 & 11 & 11 & 11 & 11 & 11 & 11 & 11 & 11 & 11 \\ 86 & 23 & 11 & 13 & 11 & 11 & 11 & 11 & 11 & 11 & 11 & 11 & 11 & 11 & 11 \\ 87 & 11 & 11 & 23 & 12 & 12 & 12 & 11 & 11 & 11 & 11 & 11 & 11 & 11 & 11 \\ 88 & 12 & 11 & 23 & 12 & 12 & 22 & 11 & 11 & 11 & 11 & 11 & 11 & 11 & 12 \\ 89 & 13 & 11 & 11 & 11 & 11 & 11 & 11 & 11 & 11 & 11 & 11 & 11 & 11 & 22 \\ 90 & 12 & 11 & 12 & 22 & 12 & 12 & 11 & 11 & 11 & 11 & 11 & 11 & 11 & 12 \\ 91 & 12 & 11 & 12 & 11 & 12 & 11 & 11 & 11 & 11 & 11 & 11 & 11 & 11 & 11 \\ 92 & 13 & 11 & 13 & 12 & 12 & 11 & 11 & 11 & 11 & 11 & 11 & 11 & 11 & 11 \\ 93 & 33 & 11 & 33 & 11 & 11 & 11 & 11 & 11 & 11 & 11 & 11 & 11 & 11 & 11 \\ 94 & 33 & 11 & 23 & 12 & 12 & 11 & 11 & 11 & 11 & 11 & 11 & 11 & 11 & 11 \\ 95 & 23 & 11 & 33 & 11 & 12 & 11 & 11 & 11 & 11 & 11 & 11 & 11 & 11 & 12 \\ 96 & 23 & 11 & 13 & 12 & 12 & 12 & 11 & 11 & 11 & 11 & 11 & 11 & 11 & 11 \\ 97 & 33 & 11 & 13 & 12 & 11 & 11 & 11 & 11 & 11 & 11 & 11 & 11 & 11 & 11 \\ 98 & 13 & 11 & 13 & 11 & - & 22 & 11 & 11 & 11 & 11 & 11 & 11 & 11 & 12 \\ 99 & 23 & 11 & 13 & 11 & 11 & 11 & 11 & 11 & 11 & 11 & 11 & 11 & 11 & 12 \\ 100 & 23 & 11 & 33 & 12 & 12 & 11 & 11 & 11 & 11 & 11 & 11 & 11 & 11 & 11\end{array}$


4- Fotos de géis de eletroforese. Demonstração de padrões de gel para adultos , jovens e plântulas de Calophyllum brasiliense Camb. Piracicaba, ESALQ/USP. 1999.
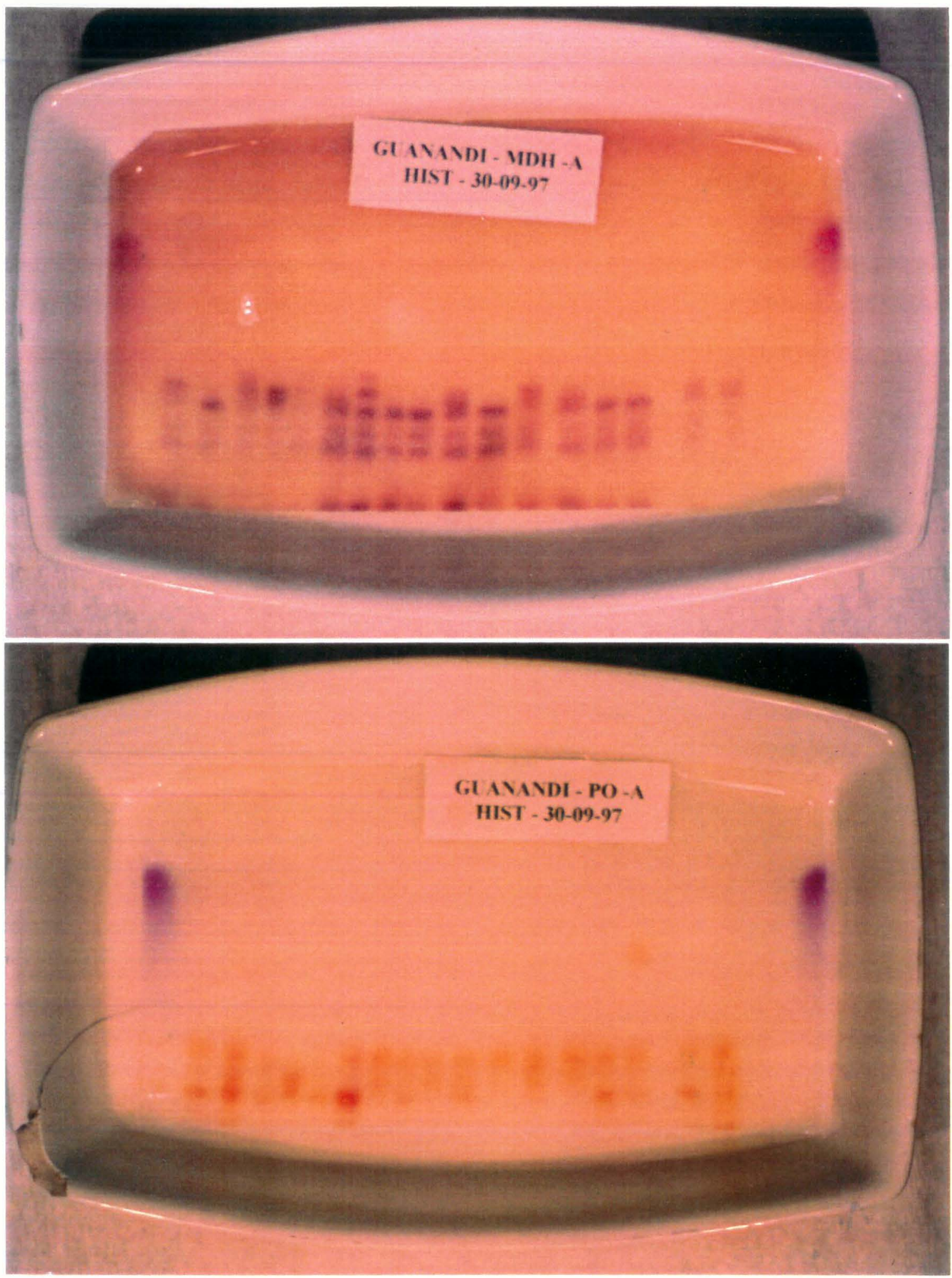